\title{
Insertion Reactions at Cyclobutylene-Bridged ansa-Metallocene Complexes: a Quest for the Influence of Covering Phenylene Units
}

\author{
Liyi Chen, Wan-Li Nie, Jan Paradies, Gerald Kehr, Roland Fröhlich ${ }^{\#}$,Katrin \\ Wedeking ${ }^{\#}$, Gerhard Erker*
}

Organisch-Chemisches Institut der Universität Münster, Corrensstr. 40, 48149

Münster, Germany

\section{Supporting Information}

Contents:

(1) Detailed NMR data and assignments for Complexes

(2) Preparation of kinetic products at low temperatures

(3) Detailed kinetic data and results 
The following assignment of NMR data is according to the Scheme 3.
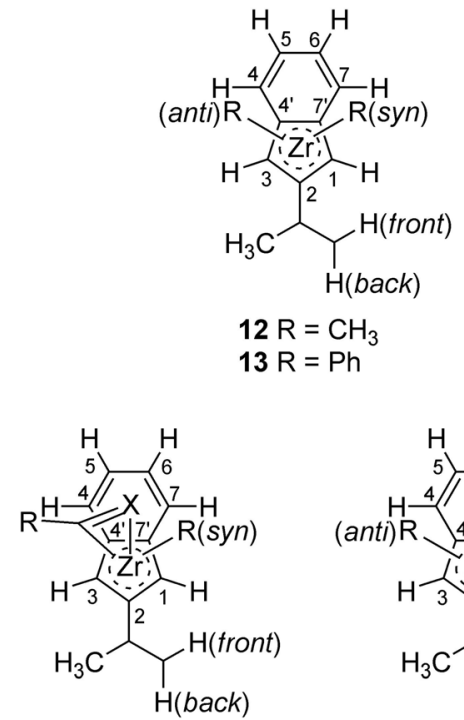

17-syn $\mathrm{R}=\mathrm{CH}_{3}, \mathrm{X}={ }^{t} \mathrm{BuN}$ 17-anti $\mathrm{R}=\mathrm{CH}_{3}, \mathrm{X}={ }^{t} \mathrm{BuN}$ 18-syn $\mathrm{R}=\mathrm{Ph}, \mathrm{X}=\mathrm{O}$ 19-syn $\mathrm{R}=\mathrm{Ph}, \mathrm{X}={ }^{t} \mathrm{BuN}$

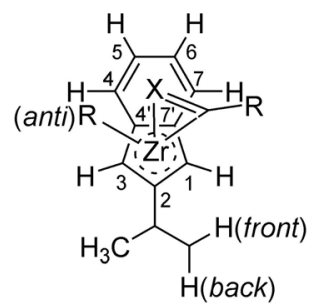

$\mathrm{R}=\mathrm{Ph}, \mathrm{X}=\mathrm{O}$

19-anti $\mathrm{R}=\mathrm{Ph}, \mathrm{X}={ }^{\mathrm{t}} \mathrm{BuN}$
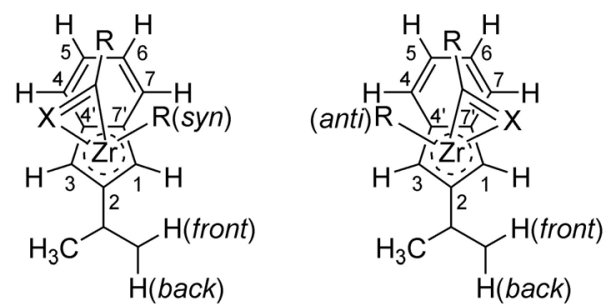

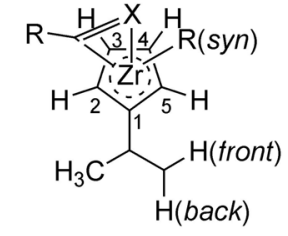

22-syn $\mathrm{R}=\mathrm{Ph}, \mathrm{X}={ }^{t} \mathrm{BuN}$

24-syn $\mathrm{R}=\mathrm{CH}_{3}, \mathrm{X}={ }^{t} \mathrm{BuN}$

$$
14 \mathrm{R}=\mathrm{CH}_{3}
$$

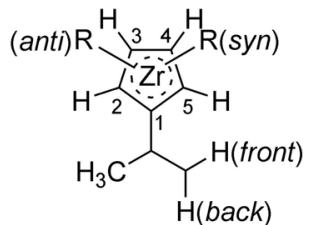

$15 \mathrm{R}=\mathrm{Ph}$

20-syn $\mathrm{R}=\mathrm{Ph}, \mathrm{X}={ }^{t} \mathrm{BuN} \quad$ 20-anti $\mathrm{R}=\mathrm{Ph}, \mathrm{X}={ }^{t} \mathrm{BuN}$

Scheme 5

\section{Dimethyl ansa-bisindenyl zirconium complex 12}

${ }^{1} \mathbf{H}$ NMR $\left(599.7 \mathrm{MHz}, 298 \mathrm{~K}, \mathrm{C}_{6} \mathrm{D}_{6}\right): \delta-1.75$ (s, 3H, $\mathrm{Zr}_{-}-\mathrm{CH}_{3}($ anti)), -0.23 (s, 3H,

$\mathrm{Zr}-\mathrm{CH}_{3}($ syn $)$, the same side with the cyclobutylene bridge), $1.17\left(\mathrm{~s}, 6 \mathrm{H}, \mathrm{CH}_{3}\right), 1.66$

(AA'BB', 2H, $\mathrm{CH}_{3} \mathrm{CCH}_{\text {back }}$ ), 2.19 (AA'BB', 2H, $\mathrm{CH}_{3} \mathrm{CCH}_{\text {front }}$ ), 5.88 (d, J = 2.3 Hz, 2H,

$\mathrm{H}-3$ in indenyl), $6.06(\mathrm{~d}, \mathrm{~J}=2.3 \mathrm{~Hz}, 2 \mathrm{H}, \mathrm{H}-1$ in indenyl, the same side with the cyclobutylene bridge), 6.90 (m, 2H, H-6 in indenyl ), 7.01 (m, 2H, H-5 in indenyl), 7.27 (m, 2H, H-4 in indenyl), 7.47 (m, 2H, H-7 in indenyl). 
${ }^{13} \mathrm{C}$ NMR $\left(150.8 \mathrm{MHz}, 298 \mathrm{~K}, \mathrm{C}_{6} \mathrm{D}_{6}\right): \delta 26.2\left(\mathrm{CH}_{3}\right), 30.6\left(\mathrm{CH}_{2}\right), 31.3\left(\mathrm{Zr}_{-} \mathrm{CH}_{3}(s y n)\right)$, $41.4\left(\mathrm{Zr}-\mathrm{CH}_{3}(\right.$ anti $\left.)\right), 49.1\left(\mathrm{CH}_{3} \mathrm{C}\right), 95.4$ (C-3 in indenyl), 98.1 (C-1 in indenyl, the same side with the cyclobutylene bridge), 123.3 (C-4' in indenyl), 124.0 (C-5 in indenyl), 124.2 (C-7 in indenyl), 124.2 (C-6 in indenyl ), 125.2 (C-4 in indenyl), 125.7 (C-7' in indenyl), 138.6 (C-2 in indenyl).

${ }^{\mathbf{1}} \mathbf{H},{ }^{\mathbf{1 3}} \mathbf{C}-\mathbf{G H S Q C}\left(599.7 \mathrm{MHz} / 150.8 \mathrm{MHz}, 298 \mathrm{~K}, \mathrm{C}_{6} \mathrm{D}_{6}\right): \delta\left({ }^{1} \mathrm{H}\right) / \delta\left({ }^{13} \mathrm{C}\right)=-1.75 / 41.4$

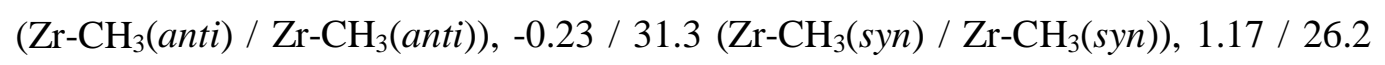
$\left(\mathrm{CH}_{3} / \mathrm{CH}_{3}\right), 1.66$ / $30.6\left(\mathrm{CH}_{3} \mathrm{CCH}_{\text {back }} / \mathrm{CH}_{2}\right), 2.19$ / $30.6\left(\mathrm{CH}_{3} \mathrm{CCH}_{\text {front }} / \mathrm{CH}_{2}\right), 5.88$ / 95.4 (H-3 in indenyl / C-3 in indenyl), 6.06 / 98.1 (H-1 in indenyl / C-1 in indenyl), 6.90 / 124.2 (H-6 in indenyl / C-6 in indenyl ), 7.01 / 124.0 (H-5 in indenyl / C-5 in indenyl), 7.27 / 125.2 (H-4 in indenyl / C-4 in indenyl), 7.47 / 124.2 (H-7 in indenyl / C-7 in indenyl).

${ }^{\mathbf{1}} \mathbf{H},{ }^{\mathbf{1 3}} \mathbf{C}$-GHMBC (599.7 MHz/150.8 MHz, $298 \mathrm{~K}, \mathrm{C}_{6} \mathrm{D}_{6}$, selected ${ }^{13} \mathrm{C}$ traces $): \delta\left({ }^{13} \mathrm{C}\right) /$ $\delta\left({ }^{1} \mathrm{H}\right)=49.1 / 1.17,1.66,2.19\left(\mathrm{CH}_{3} \mathrm{C} / \mathrm{CH}_{3}, \mathrm{CH}_{3} \mathrm{CCH}_{\text {back }}, \mathrm{CH}_{3} \mathrm{CCH}_{\text {front }}\right) ; 123.3$ / 5.88, 6.06, 6.90, 7.27 (C-4' in indenyl / H-3 in indenyl, H-1 in indenyl, H-6 in indenyl, H-4 in indenyl); 125.7 / 5.88, 6.06, 7.01, 7.47 (C-7' in indenyl / H-3 in indenyl, H-1 in indenyl, H-5 in indenyl, H-7 in indenyl); 138.6 / 1.17, 1.66, 2.19, 5.88, 6.06 (C-2 in indenyl / $\mathrm{CH}_{3}, \mathrm{CH}_{3} \mathrm{CCH}_{\text {back }}, \mathrm{CH}_{3} \mathrm{CCH}_{\text {front }}, \mathrm{H}-3$ in indenyl, $\mathrm{H}-1$ in indenyl).

${ }^{1} \mathbf{H}\left\{{ }^{1} \mathbf{H}\right\}$-NOE $\left(599.7 \mathrm{MHz}, 298 \mathrm{~K}, \mathrm{C}_{6} \mathrm{D}_{6}\right): \delta\left({ }^{1} \mathrm{H}\right)_{\text {irradiation }} / \delta\left({ }^{1} \mathrm{H}\right)_{\text {response }}=-1.75 /-0.23$,

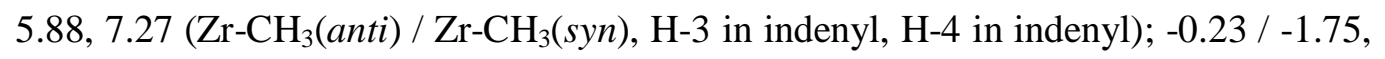

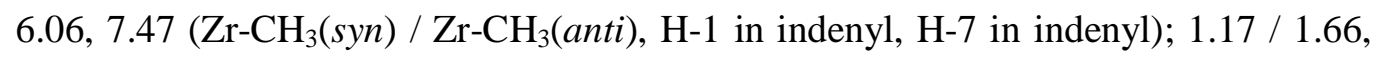
$5.88\left(\mathrm{CH}_{3} / \mathrm{CH}_{3} \mathrm{CCH}_{\text {back }}, \mathrm{H}-3\right.$ in indenyl $) ; 1.66 / 1.17,2.19\left(\mathrm{CH}_{3} \mathrm{CCH}_{\text {back }} / \mathrm{CH}_{3}\right.$, 
$\left.\mathrm{CH}_{3} \mathrm{CCH}_{\text {front }}\right) ; 2.19$ / 1.66, $6.06\left(\mathrm{CH}_{3} \mathrm{CCH}_{\text {front }} / \mathrm{CH}_{3} \mathrm{CCH}_{\text {back }}, \mathrm{H}-1\right.$ in indenyl); 5.88 / $-1.75,1.17,7.27$ (H-3 in indenyl / $\mathrm{Zr}_{-} \mathrm{CH}_{3}\left(\right.$ anti) $, \mathrm{CH}_{3}, \mathrm{H}-4$ in indenyl); 6.06 / -0.23, 2.19, 7.47 (H-1 in indenyl / $\mathrm{Zr}-\mathrm{CH}_{3}\left(\right.$ syn), $\mathrm{CH}_{3} \mathrm{CCH}_{\text {front }}$, H-7 in indenyl); 6.90 / -1.75,

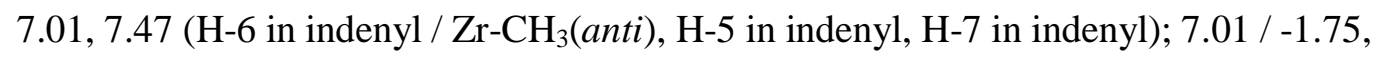
6.90, 7.27 (H-5 in indenyl / $\mathrm{Zr}-\mathrm{CH}_{3}$ (anti), H-6 in indenyl, H-4 in indenyl); 7.27 / -1.75, 5.88, 7.01 (H-4 in indenyl / Zr-CH$($ anti), H-3 in indenyl, H-5 in indenyl); 7.47 / -0.23, 6.06, 6.90 (H-7 in indenyl / $\mathrm{Zr}-\mathrm{CH}_{3}(\mathrm{syn}), \mathrm{H}-1$ in indenyl, H-6 in indenyl).

\section{Diphenyl ansa-bisindenyl zirconium complex 13}

${ }^{1} \mathbf{H}$ NMR $\left(599.7 \mathrm{MHz}, 298 \mathrm{~K}, \mathrm{C}_{6} \mathrm{D}_{5} \mathrm{CD}_{3}\right): \delta 1.21\left(\mathrm{~s}, 6 \mathrm{H}, \mathrm{CH}_{3}\right), 1.73\left(\mathrm{AA}^{\prime} \mathrm{BB}\right.$ ', $2 \mathrm{H}$, $\mathrm{CH}_{3} \mathrm{CCH}_{\text {back }}$ ), $2.45\left(\mathrm{AA}^{\prime} \mathrm{BB}^{\prime}, 2 \mathrm{H}, \mathrm{CH}_{3} \mathrm{CCH}_{\text {front }}\right), 6.12(\mathrm{dd}, \mathrm{J}=2.46 \mathrm{~Hz}, \mathrm{~J}=0.72 \mathrm{~Hz}$, $2 \mathrm{H}, \mathrm{H}-3$ in indenyl), $6.24(\mathrm{dd}, \mathrm{J}=2.46 \mathrm{~Hz}, \mathrm{~J}=0.72 \mathrm{~Hz}, 2 \mathrm{H}, \mathrm{H}-1$ in indenyl, the same side with the cyclobutylene bridge), 6.28 (m, 2H, H-5 in indenyl), 6.36 (m, 2H, H-6 in indenyl), 6.65 (m, 2H, H-7 in indenyl), 6.71 (m, 2H, H-4 in indenyl), 6.81 (m, 2H, o-H in anti-Ph), $6.95(\mathrm{~m}, 1 \mathrm{H}, p-\mathrm{H}$ in anti-Ph), $6.97(\mathrm{~m}, 2 \mathrm{H}, m-\mathrm{H}$ in anti- $\mathrm{Ph}), 7.05(\mathrm{~m}, 2 \mathrm{H}$, $m-\mathrm{H}$ in syn- $\mathrm{Ph}$, the same side with the cyclobutylene bridge $), 7.08(\mathrm{~m}, 2 \mathrm{H}, o-\mathrm{H}$ in syn- $\mathrm{Ph}$, the same side with the cyclobutylene bridge), $7.11(\mathrm{~m}, 1 \mathrm{H}, p-\mathrm{H}$ in $s y n-\mathrm{Ph}$, the same side with the cyclobutylene bridge).

${ }^{13}$ C NMR (150.8 MHz, 298K, $\left.\mathrm{C}_{6} \mathrm{D}_{5} \mathrm{CD}_{3}\right): \delta 25.5\left(\mathrm{CH}_{3}\right), 31.0\left(\mathrm{CH}_{2}\right), 49.3\left(\mathrm{CH}_{3} \mathrm{C}\right), 97.6$ (C-3 in indenyl), 99.7 (C-1 in indenyl, the same side with the cyclobutylene bridge), 123.8 (C-5 in indenyl), 123.9 (C-6 in indenyl), 124.5 (C-7 in indenyl), 124.9 (C-7' in indenyl), 125.5 (C-4 in indenyl), 125.5 ( $p-\mathrm{C}$ in anti-Ph), 126.0 ( $m-\mathrm{C}$ in $s y n-\mathrm{Ph}$, the same side with the cyclobutylene bridge), 126.4 ( $m$-C in anti-Ph), 126.4 ( $p$-C in syn-Ph, 
the same side with the cyclobutylene bridge), 127.7 (C-4' in indenyl), 134.0 ( $o-\mathrm{C}$ in syn- $\mathrm{Ph}$, the same side with the cyclobutylene bridge), 135.5 (o-C in anti-Ph), 141.8 (C-2 in indenyl), 188.6 ( $\mathrm{Zr}-\mathrm{C}$ in syn-Ph, the same side with the cyclobutylene bridge), $188.6(\mathrm{Zr}-\mathrm{C}$ in anti-Ph).

${ }^{\mathbf{1}} \mathbf{H},{ }^{13} \mathbf{C}$-GHSQC $\left(599.7 \mathrm{MHz} / 150.8 \mathrm{MHz}, 298 \mathrm{~K}, \mathrm{C}_{6} \mathrm{D}_{5} \mathrm{CD}_{3}\right): \delta\left({ }^{1} \mathrm{H}\right) / \delta\left({ }^{13} \mathrm{C}\right)=1.21 /$ $25.5\left(\mathrm{CH}_{3} / \mathrm{CH}_{3}\right), 1.73 / 31.0\left(\mathrm{CH}_{3} \mathrm{CCH}_{\text {back }} / \mathrm{CH}_{2}\right), 2.45 / 31.0\left(\mathrm{CH}_{3} \mathrm{CCH}_{\text {front }} / \mathrm{CH}_{2}\right)$, 6.12 / 97.6 (H-3 in indenyl / C-3 in indenyl), 6.24 / 99.7 (H-1 in indenyl / C-1 in indenyl), 6.28 / 123.8 (H-5 in indenyl / C-5 in indenyl), 6.36 / 123.9 (H-6 in indenyl / C-6 in indenyl), 6.65 / 124.5 (H-7 in indenyl / C-7 in indenyl), $6.71 / 125.5$ (H-4 in indenyl / C-4 in indenyl), 6.81 / 135.5 (o-H in anti-Ph / o-C in anti-Ph), 6.95 / 125.5 (p-H in anti-Ph / p-C in anti-Ph), 6.97 / $126.4(m-\mathrm{H}$ in anti-Ph / $m-\mathrm{C}$ in anti-Ph), 7.05 / $126.0(m-\mathrm{H}$ in $s y n-\mathrm{Ph} / m-\mathrm{C}$ in $s y n-\mathrm{Ph}), 7.08 / 134.0$ (o-H in $s y n-\mathrm{Ph} / o-\mathrm{C}$ in $s y n-\mathrm{Ph})$, $7.11 / 126.4$ ( $p-\mathrm{H}$ in syn-Ph / p-C in syn-Ph),

${ }^{\mathbf{1}} \mathbf{H},{ }^{\mathbf{1 3}} \mathbf{C}-\mathbf{G H M B C}\left(599.7 \mathrm{MHz} / 150.8 \mathrm{MHz}, 298 \mathrm{~K}, \mathrm{C}_{6} \mathrm{D}_{5} \mathrm{CD}_{3}\right.$, selected ${ }^{13} \mathrm{C}$ traces $): \delta$ $\left({ }^{13} \mathrm{C}\right) / \delta\left({ }^{1} \mathrm{H}\right)=49.3 / 1.21,1.73,2.45\left(\mathrm{CH}_{3} \mathrm{C} / \mathrm{CH}_{3}, \mathrm{CH}_{3} \mathrm{CCH}_{\text {back }}, \mathrm{CH}_{3} \mathrm{CCH}_{\text {front }}\right) ; 124.9$ / 6.12, 6.24, 6.36, 6.71 (C-7' in indenyl / H-3 in indenyl, H-1 in indenyl, H-6 in indenyl, $\mathrm{H}-4$ in indenyl); 127.7 / 6.12, 6.24, 6.28, 6.65 (C-4' in indenyl / H-3 in indenyl, H-1 in indenyl, H-5 in indenyl, H-7 in indenyl); 141.8 / 1.21, 1.73, 2.45, 6.12, 6.24 (C-2 in indenyl / $\mathrm{CH}_{3}, \mathrm{CH}_{3} \mathrm{CCH}_{\text {back }}, \mathrm{CH}_{3} \mathrm{CCH}_{\text {front }}, \mathrm{H}-3$ in indenyl, $\mathrm{H}-1$ in indenyl); 188.6 / 7.05, 7.08, 7.11 (Zr-C in syn-Ph / $m-\mathrm{H}$ in syn-Ph, $o-\mathrm{H}$ in syn- $\mathrm{Ph}, p-\mathrm{H}$ in syn-Ph); 188.6 / 6.81, 6.95, 6.97 ( $\mathrm{Zr}-\mathrm{C}$ in anti-Ph / $o-\mathrm{H}$ in anti-Ph, $p-\mathrm{H}$ in anti-Ph, $m-\mathrm{H}$ in anti-Ph). ${ }^{1} \mathbf{H}\left\{{ }^{1} \mathbf{H}\right\}$-TOCSY $\left(599.7 \mathrm{MHz}, 298 \mathrm{~K}, \mathrm{C}_{6} \mathrm{D}_{5} \mathrm{CD}_{3}\right.$, selected experiments $): \delta\left({ }^{1} \mathrm{H}\right)_{\text {irradiation }}$ 
$/ \delta\left({ }^{1} \mathrm{H}\right)_{\text {response }}=6.71 / 6.28,6.36,6.65(\mathrm{H}-4$ in indenyl / H-5 in indenyl, H-6 in indenyl, $\mathrm{H}-7$ in indenyl); $6.81 / 6.95,6.97(o-\mathrm{H}$ in anti-Ph / $p-\mathrm{H}$ in anti-Ph, $m-\mathrm{H}$ in anti-Ph); $7.11 / 7.05,7.08$ ( $p-\mathrm{H}$ in $s y n-\mathrm{Ph} / m-\mathrm{H}$ in $s y n-\mathrm{Ph}, o-\mathrm{H}$ in $s y n-\mathrm{Ph})$.

${ }^{1} \mathbf{H}\left\{{ }^{1} \mathbf{H}\right\}$-NOE $\left(599.7 \mathrm{MHz}, 298 \mathrm{~K}, \mathrm{C}_{6} \mathrm{D}_{5} \mathrm{CD}_{3}\right): \delta\left({ }^{1} \mathrm{H}\right)_{\text {irradiation }} / \delta\left({ }^{1} \mathrm{H}\right)_{\text {response }}=1.21 /$ 1.73, $6.12\left(\mathrm{CH}_{3} / \mathrm{CH}_{3} \mathrm{CCH}_{\text {back }}, \mathrm{H}-3\right.$ in indenyl $) ; 1.73 / 1.21,2.45\left(\mathrm{CH}_{3} \mathrm{CCH}_{\text {back }} / \mathrm{CH}_{3}\right.$, $\left.\mathrm{CH}_{3} \mathrm{CCH}_{\text {front }}\right) ; 2.45$ / 1.73, $6.24\left(\mathrm{CH}_{3} \mathrm{CCH}_{\text {front }} / \mathrm{CH}_{3} \mathrm{CCH}_{\text {back }}, \mathrm{H}-1\right.$ in indenyl $) ; 6.12$ / 1.21, 6.71, $6.81\left(\mathrm{H}-3\right.$ in indenyl / $\mathrm{CH}_{3}, \mathrm{H}-4$ in indenyl, $o-\mathrm{H}$ in anti-Ph); 6.24 / 2.45, 6.65, 7.08 (H-1 in indenyl / $\mathrm{CH}_{3} \mathrm{CCH}_{\text {front }}, \mathrm{H}-7$ in indenyl, $o-\mathrm{H}$ in syn-Ph); 6.28 / 6.36, 6.71 (H-5 in indenyl / H-6 in indenyl, H-4 in indenyl); 6.36 / 6.28, 6.65 (H-6 in indenyl / H-5 in indenyl, H-7 in indenyl); 6.65 / 6.24, 6.36, 7.08 ( $\mathrm{H}-7$ in indenyl / $\mathrm{H}-1$ in indenyl, H-6 in indenyl, $o-\mathrm{H}$ in syn- $\mathrm{Ph}) ; 6.71$ / 6.12, 6.28 (H-4 in indenyl / $\mathrm{H}-3$ in indenyl, H-5 in indenyl); 6.81 / 6.12, 6.71, 6.97, 7.08 (o-H in anti-Ph / H-3 in indenyl, $\mathrm{H}-4$ in indenyl, $m-\mathrm{H}$ in anti-Ph, $o-\mathrm{H}$ in $s y n-\mathrm{Ph})$.

\section{Dimethyl ansa-biscyclopentadienyl zirconium complex 14}

${ }^{1} \mathbf{H}$ NMR (599.8 MHz, 298K, $\left.\mathrm{C}_{6} \mathrm{D}_{5} \mathrm{CD}_{3}\right): \delta-0.22$ (s, 3H, Zr-CH$($ anti)), -0.10 (s, 3H, $\mathrm{Zr}-\mathrm{CH}_{3}(\mathrm{syn})$, the same side with the cyclobutylene bridge), $0.96\left(\mathrm{~s}, 6 \mathrm{H}, \mathrm{CH}_{3}\right), 1.50$ (AA'BB', 2H, $\left.\mathrm{CH}_{3} \mathrm{CCH}_{\text {back }}\right), 1.94$ (AA'BB', 2H, $\left.\mathrm{CH}_{3} \mathrm{CCH}_{\text {front }}\right), 5.31$ (m, 2H, H-2 in Cp), 5.66 (m, 2H, H-5 in Cp, the same side with the cyclobutylene bridge), $6.20(\mathrm{~m}, 2 \mathrm{H}$, $\mathrm{H}-4$ in $\mathrm{Cp}$ ), 6.38 (m, 2H, H-3 in Cp).

${ }^{13} \mathrm{C}$ NMR (150.8 MHz, 298K, $\left.\mathrm{C}_{6} \mathrm{D}_{5} \mathrm{CD}_{3}\right): \delta 25.5\left(\mathrm{CH}_{3}\right), 28.2\left(\mathrm{Zr}_{-}-\mathrm{CH}_{3}(\right.$ anti $\left.)\right), 29.2$ $\left(\mathrm{Zr}-\mathrm{CH}_{3}(s y n)\right), 30.6\left(\mathrm{CH}_{2}\right), 48.8\left(\mathrm{CH}_{3} \mathrm{C}\right), 104.7(\mathrm{C}-2$ in $\mathrm{Cp}), 106.7$ (in $\mathrm{C}-5 \mathrm{Cp}$, the same side with the cyclobutylene bridge), 113.4 (C-4 in Cp), 116.7 (C-3 in Cp), 134.1 
(C-1 in $\mathrm{Cp})$.

${ }^{1} \mathbf{H},{ }^{13} \mathbf{C}-G H S Q C\left(599.7 \mathrm{MHz} / 150.8 \mathrm{MHz}, 298 \mathrm{~K}, \mathrm{C}_{6} \mathrm{D}_{6}\right): \delta\left({ }^{1} \mathrm{H}\right) / \delta\left({ }^{13} \mathrm{C}\right)=-0.22 /$

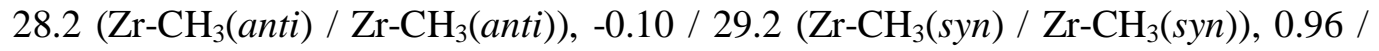

$25.5\left(\mathrm{CH}_{3} / \mathrm{CH}_{3}\right), 1.50$ / $30.6\left(\mathrm{CH}_{3} \mathrm{CCH}_{\text {back }} / \mathrm{CH}_{2}\right), 1.94$ / $30.6\left(\mathrm{CH}_{3} \mathrm{CCH}_{\text {front }} / \mathrm{CH}_{2}\right)$,

5.31 / 104.7 (H-2 in Cp / C-2 in Cp), 5.66 / 106.7 (H-5 in Cp / in C-5 Cp), 6.20 / 113.4

(H-4 in Cp / C-4 in Cp), 6.38 / 116.7 (H-3 in Cp / C-3 in Cp).

${ }^{\mathbf{1}} \mathbf{H},{ }^{\mathbf{1 3}} \mathbf{C}$-GHMBC $\left(599.7 \mathrm{MHz} / 150.8 \mathrm{MHz}, 298 \mathrm{~K}, \mathrm{C}_{6} \mathrm{D}_{6}\right.$, selected ${ }^{13} \mathrm{C}$ traces $): \delta\left({ }^{1} \mathrm{H}\right) /$

$\delta\left({ }^{13} \mathrm{C}\right)=48.8 / 0.96,1.50,1.94\left(\mathrm{CH}_{3} \mathrm{C} / \mathrm{CH}_{3}, \mathrm{CH}_{3} \mathrm{CCH}_{\text {back }}, \mathrm{CH}_{3} \mathrm{CCH}_{\text {front }}\right) ; 134.1 / 0.96$, 1.50, 1.94 (C-1 in $\left.\mathrm{Cp} / \mathrm{CH}_{3}, \mathrm{CH}_{3} \mathrm{CCH}_{\text {back }}, \mathrm{CH}_{3} \mathrm{CCH}_{\text {front }}\right)$.

${ }^{1} \mathbf{H}\left\{{ }^{1} \mathbf{H}\right\}$-NOE $\left(599.7 \mathrm{MHz}, 298 \mathrm{~K}, \mathrm{C}_{6} \mathrm{D}_{6}\right): \delta\left({ }^{1} \mathrm{H}\right)_{\text {irradiation }} / \delta\left({ }^{1} \mathrm{H}\right)_{\text {response }}=-0.22 / 5.31$,

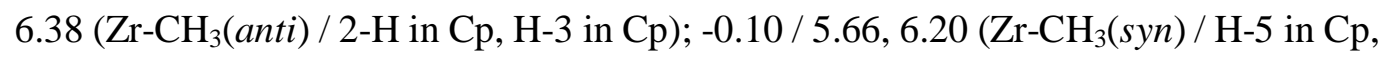
$\mathrm{H}-4$ in $\mathrm{Cp}) ; 0.96$ / 1.50, $5.31\left(\mathrm{CH}_{3} / \mathrm{CH}_{3} \mathrm{CCH}_{\text {back }}, \mathrm{H}-2\right.$ in $\left.\mathrm{Cp}\right) ; 1.50$ / 0.96, 1.94 $\left(\mathrm{CH}_{3} \mathrm{CCH}_{\text {back }} / \mathrm{CH}_{3}, \mathrm{CH}_{3} \mathrm{CCH}_{\text {front }}\right) ; 1.94$ / 1.50, $5.66\left(\mathrm{CH}_{3} \mathrm{CCH}_{\text {front }} / \mathrm{CH}_{3} \mathrm{CCH}_{\text {back }}, \mathrm{H}-5\right.$

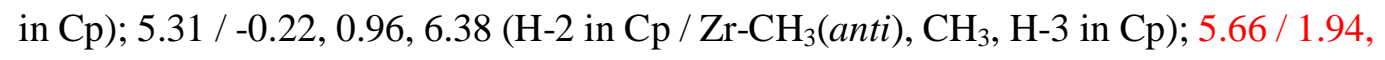
6.20 (H-5 in $\mathrm{Cp} / \mathrm{CH}_{3} \mathrm{CCH}_{\text {front }}, \mathrm{H}-4$ in $\left.\mathrm{Cp}\right) ; 6.20$ / -0.22, -0.10, 5.66, 6.38 (H-4 in Cp / Zr- $\mathrm{CH}_{3}$ (anti), $\mathrm{Zr}-\mathrm{CH}_{3}($ syn), H-5 in Cp, H-3 in Cp); 6.38 / -0.22, -0.10, 5.31 (H-3 in Cp / $\mathrm{Zr}-\mathrm{CH}_{3}\left(\right.$ anti), $\mathrm{Zr}-\mathrm{CH}_{3}($ syn $), \mathrm{H}-2$ in $\left.\mathrm{Cp}\right)$.

\section{Diphenyl ansa-biscyclopentadienyl zirconium complex 15}

${ }^{1} \mathbf{H}$ NMR $\left(599.7 \mathrm{MHz}, 298 \mathrm{~K}, \mathrm{C}_{6} \mathrm{D}_{5} \mathrm{CD}_{3}\right): \delta 1.02\left(\mathrm{~s}, 6 \mathrm{H}, \mathrm{CH}_{3}\right), 1.58\left(\mathrm{AA}^{\prime} \mathrm{BB}\right.$ ', $2 \mathrm{H}$, $\mathrm{CH}_{3} \mathrm{CCH}_{\text {back }}$ ), 2.15 (AA'BB', 2H CH $\mathrm{CCH}_{\text {front }}$ ), 5.60 (m, 2H, H-2 in $\mathrm{Cp}$ ), 5.86 (m, 2H, H-5 in Cp, the same side with the cyclobutylene bridge), 6.07 (m, 2H, H-4 in Cp), 6.26 (m, 2H, H-3 in $\mathrm{Cp}), 7.06(\mathrm{~m}, 1 \mathrm{H}, p-\mathrm{H}$ in anti-Ph), $7.08(\mathrm{~m}, 1 \mathrm{H}, p-\mathrm{H}$ in $s y n-\mathrm{Ph}$, the same 
side with the cyclobutylene bridge), $7.15(\mathrm{~m}, 2 \mathrm{H}, m-\mathrm{H}$ in anti-Ph), $7.17(\mathrm{~m}, 2 \mathrm{H}, m-\mathrm{H}$ in syn- $\mathrm{Ph}$, the same side with the cyclobutylene bridge), $7.32(\mathrm{~m}, 2 \mathrm{H}, o-\mathrm{H}$ in anti- $\mathrm{Ph})$, $7.45(\mathrm{~m}, 2 \mathrm{H}, o-\mathrm{H}$ in syn- $\mathrm{Ph}$, the same side with the cyclobutylene bridge).

${ }^{13}$ C NMR $\left(150.8 \mathrm{MHz}, 298 \mathrm{~K}, \mathrm{C}_{6} \mathrm{D}_{5} \mathrm{CD}_{3}\right): \delta 25.3\left(\mathrm{CH}_{3}\right), 30.8\left(\mathrm{CH}_{2}\right), 49.1\left(\mathrm{CH}_{3} \mathrm{C}\right)$, 106.3 (C-2 in $\mathrm{Cp}$ ), 108.0 (C-5 in $\mathrm{Cp}$, the same side with the cyclobutylene bridge), 116.1 (C-4 in Cp), 119.4 (C-3 in Cp), 125.8 ( $p$-C in anti-Ph ), 126.1 ( $p$-C in syn-Ph, the same side with the cyclobutylene bridge), 126.8 ( $m$-C in syn- and anti-Ph), 135.9 ( $o-\mathrm{C}$ in syn-Ph, the same side with the cyclobutylene bridge), 136.1 ( $o-\mathrm{C}$ in anti-Ph), 137.0 (C-1 in $\mathrm{Cp}), 182.5$ (Zr-C in anti-Ph), 183.0 ( $\mathrm{Zr}-\mathrm{C}$ in syn-Ph, the same side with the cyclobutylene bridge).

${ }^{1} \mathbf{H},{ }^{13} \mathbf{C}-G H S Q C\left(599.7 \mathrm{MHz} / 150.8 \mathrm{MHz}, 298 \mathrm{~K}, \mathrm{C}_{6} \mathrm{D}_{5} \mathrm{CD}_{3}\right): \delta\left({ }^{1} \mathrm{H}\right) / \delta\left({ }^{13} \mathrm{C}\right)=1.02 /$ $25.3\left(\mathrm{CH}_{3} / \mathrm{CH}_{3}\right), 1.58 / 30.8\left(\mathrm{CH}_{3} \mathrm{CCH}_{\text {back }} / \mathrm{CH}_{2}\right), 2.15 / 30.8\left(\mathrm{CH}_{3} \mathrm{CCH}_{\text {front }} / \mathrm{CH}_{2}\right)$, 5.60 / 106.3 (H-2 in Cp / C-2 in Cp), 5.86 / 108.0 (H-5 in Cp / C-5 in Cp), 6.07 / 116.1 (H-4 in Cp / C-4 in Cp), 6.26 / 119.4 (H-3 in Cp / C-3 in Cp), 7.06 / 125.8 (p-H in anti-Ph / p-C in anti-Ph ), 7.08 / 126.1 ( $p-\mathrm{H}$ in syn- $\mathrm{Ph} / p-\mathrm{C}$ in $s y n-\mathrm{Ph}), 7.15$ / 126.8 ( $m-\mathrm{H}$ in anti-Ph / $m-\mathrm{C}$ in anti-Ph), $7.17 / 126.8$ ( $m-\mathrm{H}$ in syn-Ph / $m-\mathrm{C}$ in $s y n-\mathrm{Ph}), 7.32$ / 136.1 (o-H in anti-Ph / o-C in anti-Ph), 7.45 / 135.9 (o-H in syn-Ph / o-C in syn-Ph). ${ }^{\mathbf{1}} \mathbf{H},{ }^{\mathbf{1 3}} \mathbf{C - G H M B C}\left(599.7 \mathrm{MHz} / 150.8 \mathrm{MHz}, 298 \mathrm{~K}, \mathrm{C}_{6} \mathrm{D}_{5} \mathrm{CD}_{3}\right.$, selected ${ }^{13} \mathrm{C}$ traces $): \delta$ $\left({ }^{13} \mathrm{C}\right) / \delta\left({ }^{1} \mathrm{H}\right)=49.1 / 1.02,1.58,2.15\left(\mathrm{CH}_{3} \mathrm{C} / \mathrm{CH}_{3}, \mathrm{CH}_{3} \mathrm{CCH}_{\text {back }}, \mathrm{CH}_{3} \mathrm{CCH}_{\text {front }}\right) ; 137.0$ / 1.02, 1.58, 2.15, 5.60, 5.86, 6.07, $6.26\left(\mathrm{C}-1\right.$ in $\mathrm{Cp} / \mathrm{CH}_{3}, \mathrm{CH}_{3} \mathrm{CCH}_{\text {back }}, \mathrm{CH}_{3} \mathrm{CCH}_{\text {front }}$, H-2 in Cp, H-5 in Cp, H-4 in Cp, H-3 in Cp); 182.5 / 7.15, 7.32 (Zr-C in anti-Ph / m-H in anti- $\mathrm{Ph}, o-\mathrm{H}$ in anti-Ph), $183.0 / 7.17,7.45(\mathrm{Zr}-\mathrm{C}$ in $s y n-\mathrm{Ph} / m-\mathrm{H}$ in $s y n-\mathrm{Ph}, o-\mathrm{H}$ in 
syn-Ph).

${ }^{1} \mathbf{H}\left\{{ }^{1} \mathbf{H}\right\}$-TOCSY $\left(599.7 \mathrm{MHz}, 298 \mathrm{~K}, \mathrm{C}_{6} \mathrm{D}_{5} \mathrm{CD}_{3}\right.$, selected experiments $): \delta\left({ }^{1} \mathrm{H}\right)_{\text {irradiation }}$ $/ \delta\left({ }^{1} \mathrm{H}\right)_{\text {response }}=7.45 / 7.08,7.17(o-\mathrm{H}$ in $s y n-\mathrm{Ph} / p-\mathrm{H}$ in $s y n-\mathrm{Ph}, m-\mathrm{H}$ in $s y n-\mathrm{Ph}) ; 7.32$ / 7.06, 7.15 (o-H in anti-Ph / $p-\mathrm{H}$ in anti-Ph, $m-\mathrm{H}$ in anti-Ph).

${ }^{1} \mathbf{H}\left\{{ }^{1} \mathbf{H}\right\}$-NOE $\left(599.7 \mathrm{MHz}, 298 \mathrm{~K}, \mathrm{C}_{6} \mathrm{D}_{5} \mathrm{CD}_{3}\right): \delta\left({ }^{1} \mathrm{H}\right)_{\text {irradiation }} / \delta\left({ }^{1} \mathrm{H}\right)_{\text {response }}=1.02 /$ 1.58, $5.60\left(\mathrm{CH}_{3} / \mathrm{CH}_{3} \mathrm{CCH}_{\text {back }}, \mathrm{H}-2\right.$ in $\left.\mathrm{Cp}\right) ; 1.58 / 1.02,2.15\left(\mathrm{CH}_{3} \mathrm{CCH}_{\text {back }} / \mathrm{CH}_{3}\right.$, $\left.\mathrm{CH}_{3} \mathrm{CCH}_{\text {front }}\right) ; 2.15$ / 1.58, $5.86\left(\mathrm{CH}_{3} \mathrm{CCH}_{\text {front }} / \mathrm{CH}_{3} \mathrm{CCH}_{\text {back }}, 5-\mathrm{H}\right.$ in $\left.\mathrm{Cp}\right) ; 5.60$ / 1.02, 6.26, $7.32\left(\mathrm{H}-2\right.$ in $\mathrm{Cp} / \mathrm{CH}_{3}, \mathrm{H}-3$ in $\mathrm{Cp}, o-\mathrm{H}$ in anti-Ph); 5.86 / 2.15, 6.07, 7.45 (H-5 in $\mathrm{Cp} / \mathrm{CH}_{3} \mathrm{CCH}_{\text {front }}, \mathrm{H}-4$ in $\mathrm{Cp}, o-\mathrm{H}$ in syn- $\left.\mathrm{Ph}\right) ; 6.07$ / 5.86, 6.26, 7.45 (H-4 in Cp / H-5 in Cp, H-3 in Cp, o-H in syn-Ph); 6.26 / 5.60, 6.07, 7.32 (H-3 in Cp / H-2 in Cp, H-4 in Cp, $o-\mathrm{H}$ in anti-Ph); 7.15 / 7.06, $7.32(m-\mathrm{H}$ in anti- $\mathrm{Ph} / p-\mathrm{H}$ in anti-Ph, $o-\mathrm{H}$ in anti-Ph); 7.17 / 7.08, 7.45 ( $m-\mathrm{H}$ in syn-Ph / p-H in syn-Ph, $o-\mathrm{H}$ in $s y n-\mathrm{Ph}) ; 7.32$ / 5.60, 6.26, 7.15, 7.45 (o-H in anti-Ph / 2-H in Cp, 3-H in $\mathrm{Cp}, m-\mathrm{H}$ in anti-Ph, $o-\mathrm{H}$ in $s y n-\mathrm{Ph}) ; 7.45$ / 5.86, 6.07, 7.17, 7.32 (o-H in syn- $\mathrm{Ph} / 5-\mathrm{H}$ in $\mathrm{Cp}, \mathrm{H}-4$ in $\mathrm{Cp}, m-\mathrm{H}$ in syn- $\mathrm{Ph}, o-\mathrm{H}$ in anti-Ph). $\eta^{2}$-N-tert-butyliminoacetyl methyl ansa-bisindenyl zirconium complexes 17 17-syn $\left(\mathrm{Zr}-\mathrm{CH}_{3}\right.$ is at the same side with the cyclobutylene bridge, maojor product):

${ }^{1} \mathbf{H}$ NMR $\left(599.7 \mathrm{MHz}, 298 \mathrm{~K}, \mathrm{C}_{6} \mathrm{D}_{5} \mathrm{CD}_{3}\right.$, small amount of $\left.{ }^{t} \mathrm{BuNC}\right): \delta=0.26(\mathrm{~s}, 3 \mathrm{H}$, $\left.\mathrm{Zr}-\mathrm{CH}_{3}\right), 0.58\left(\mathrm{~s}, 9 \mathrm{H},{ }^{t} \mathrm{BuN}=\mathrm{C}-\mathrm{Zr}\right), 1.22\left(\mathrm{~s}, 6 \mathrm{H}, \mathrm{CH}_{3}\right), 1.72 \quad\left(\mathrm{AA}^{\prime} \mathrm{BB}{ }^{\prime}, \quad 2 \mathrm{H}\right.$, $\mathrm{CH}_{3} \mathrm{CCH}_{\text {back }}$ ), 2.24 (s, 3H CH $\mathrm{H}_{3} \mathrm{C}-\mathrm{Zr}$ ), $2.46\left(\mathrm{AA}^{\prime} \mathrm{BB}^{\prime}, 2 \mathrm{H} \mathrm{CH}_{3} \mathrm{CCH}_{\text {front }}\right.$ ), 5.95 (dd, J = $2.3 \mathrm{~Hz}, \mathrm{~J}=0.7 \mathrm{~Hz}, 2 \mathrm{H}, \mathrm{H}-3$ in indenyl), $6.10(\mathrm{dd}, \mathrm{J}=2.3 \mathrm{~Hz}, \mathrm{~J}=0.7 \mathrm{~Hz}, 2 \mathrm{H}, \mathrm{H}-1$ in indenyl, the same side with the cyclobutylene bridge), 6.39 (m, 2H, H-5 in indenyl ), 6.49 (m, 2H, H-6 in indenyl), 6,76 (m, 2H, H-4 in indenyl), 7.30 (m, 2H, H-7 in 
indenyl).

${ }^{13}$ C NMR (150.8 MHz, 298K, $\mathrm{C}_{6} \mathrm{D}_{5} \mathrm{CD}_{3}$, small amount of $\left.{ }^{t} \mathrm{BuNC}\right): \delta=14.4\left(\mathrm{Zr}_{-} \mathrm{CH}_{3}\right)$, $20.8\left(\mathrm{CH}_{3} \mathrm{C}-\mathrm{Zr}\right), 25.8\left(\mathrm{CH}_{3}\right), 30.8\left(\mathrm{CH}_{2}\right), 31.4\left(\mathrm{CH}_{3}\right.$ in $\left.{ }^{t} \mathrm{Bu}\right), 48.1\left(\mathrm{CH}_{3} \mathrm{C}\right), 63.9\left(\mathrm{Me}_{3} \mathrm{C}\right.$ in $\left.{ }^{t} \mathrm{Bu}\right), 87.5$ (C-3 in indenyl), 97.7 (C-1 in indenyl, the same side with the cyclobutylene bridge), 121.1 (C-7' in indenyl), 121.5 (C-6 in indenyl), 121.6 (C-4 in indenyl), 123.0 (C-5 in indenyl ), 124.4 (C-7 in indenyl), 125.6 (C-4' in indenyl), 139.5 (C-2 in indenyl), $233.1(\mathrm{~N}=\mathrm{C}-\mathrm{Zr})$.

${ }^{\mathbf{1}} \mathbf{H},{ }^{\mathbf{1 3}} \mathbf{C}$-GHSQC (599.7 MHz / 150.8 MHz, $298 \mathrm{~K}, \mathrm{C}_{6} \mathrm{D}_{5} \mathrm{CD}_{3}$, small amount of ${ }^{t} \mathrm{BuNC}$ ): $\delta\left({ }^{1} \mathrm{H}\right) / \delta\left({ }^{13} \mathrm{C}\right)=0.26 / 14.4\left(\mathrm{Zr}-\mathrm{CH}_{3} / \mathrm{Zr}-\mathrm{CH}_{3}\right), 0.58 / 31.4\left({ }^{t} \mathrm{Bu} / \mathrm{CH}_{3}\right.$ in $\left.{ }^{t} \mathrm{Bu}\right), 1.22 /$ $25.8\left(\mathrm{CH}_{3} / \mathrm{CH}_{3}\right), 1.72$ / $30.8\left(\mathrm{CH}_{3} \mathrm{CCH}_{\text {back }} / \mathrm{CH}_{2}\right), 2.24$ / $20.8\left(\mathrm{CH}_{3} \mathrm{C}-\mathrm{Zr} / \mathrm{CH}_{3} \mathrm{C}-\mathrm{Zr}\right)$, 2.46 / $30.8\left(\mathrm{CH}_{3} \mathrm{CCH}_{\text {front }} / \mathrm{CH}_{2}\right), 5.95$ / 87.5 (H-3 in indenyl / C-3 in indenyl), 6.10 / 97.7 (H-1 in indenyl / C-1 in indenyl), 6.39 / 123.0 (H-5 in indenyl / C-5 in indenyl ), 6.49 / 121.5 (H-6 in indenyl / C-6 in indenyl), 6,76 / 121.6 (H-4 in indenyl / C-4 in indenyl), 7.30 / 124.4 (H-7 in indenyl / C-7 in indenyl).

${ }^{\mathbf{1}} \mathbf{H},{ }^{\mathbf{1 3}} \mathbf{C}$-GHMBC $\left(599.7 \mathrm{MHz} / 150.8 \mathrm{MHz}, 298 \mathrm{~K}, \mathrm{C}_{6} \mathrm{D}_{5} \mathrm{CD}_{3}\right.$, small amount of ${ }^{t} \mathrm{BuNC}$, selected ${ }^{13} \mathrm{C}$ traces $): \delta\left({ }^{13} \mathrm{C}\right) / \delta\left({ }^{1} \mathrm{H}\right)=48.1 / 1.22,1.72,2.46\left(\mathrm{CH}_{3} \mathrm{C} / \mathrm{CH}_{3}, \mathrm{CH}_{3} \mathrm{CCH}_{\text {back }}\right.$, $\left.\mathrm{CH}_{3} \mathrm{CCH}_{\text {front }}\right) ; 63.9$ / $0.58\left(\mathrm{Me}_{3} \mathrm{C}\right.$ in $\left.{ }^{t} \mathrm{Bu} /{ }^{t} \mathrm{Bu}\right) ; 121.1 / 5.95,6.10,6.49,6.76(\mathrm{C}-7$ ' in indenyl / H-3 in indenyl, H-1 in indenyl, H-6 in indenyl, H-4 in indenyl); 125.6 / 5.95, 6.10, 6.39, 7.30 (C-4' in indenyl / H-3 in indenyl, H-1 in indenyl, H-5 in indenyl, H-7 in indenyl); 139.5 / 1.22, 1.72, 2.46, 5.95, 6.10 (C-2 in indenyl / $\mathrm{CH}_{3}, \mathrm{CH}_{3} \mathrm{CCH}_{\text {back }}$, $\mathrm{CH}_{3} \mathrm{CCH}_{\text {front }}, \mathrm{H}-3$ in indenyl, $\mathrm{H}-1$ in indenyl); $233.1 / 0.26,2.24\left(\mathrm{~N}=\mathrm{C}-\mathrm{Zr} / \mathrm{Zr}-\mathrm{CH}_{3}\right.$, $\left.\mathrm{CH}_{3} \mathrm{C}-\mathrm{Zr}\right)$. 
${ }^{1} \mathbf{H}\left\{{ }^{1} \mathbf{H}\right\}$-NOE $\left(599.7 \mathrm{MHz}, 298 \mathrm{~K}, \mathrm{C}_{6} \mathrm{D}_{5} \mathrm{CD}_{3}\right.$, small amount of $\left.{ }^{t} \mathrm{BuNC}\right): \delta\left({ }^{1} \mathrm{H}\right)_{\text {irradiation }} /$ $\delta\left({ }^{1} \mathrm{H}\right)_{\text {response }}=0.26 / 0.58,6.10,7.30\left(\mathrm{Zr}-\mathrm{CH}_{3} /{ }^{t} \mathrm{Bu}, \mathrm{H}-1\right.$ in indenyl, $\mathrm{H}-7$ in indenyl $)$ $0.58 / 0.26,2.24,6.39,6.49\left({ }^{t} \mathrm{Bu} / \mathrm{Zr}-\mathrm{CH}_{3}, \mathrm{CH}_{3} \mathrm{C}-\mathrm{Zr}, \mathrm{H}-5\right.$ in indenyl, H-6 in indenyl); 1.22 / 1.72, $5.95\left(\mathrm{CH}_{3}, \mathrm{CH}_{3} \mathrm{CCH}_{\text {back }}, \mathrm{H}-3\right.$ in indenyl $) ; 2.24$ / 0.58, 5.95, $6.76\left(\mathrm{CH}_{3} \mathrm{C}-\mathrm{Zr}\right.$ / ${ }^{t} \mathrm{Bu}, \mathrm{H}-3$ in indenyl, H-4 in indenyl); 5.95 / 1.22, 2.24, 6.76 (H-3 in indenyl / $\mathrm{CH}_{3}$, $\mathrm{CH}_{3} \mathrm{C}-\mathrm{Zr}, \mathrm{H}-4$ in indenyl); $6.10 / 0.26,2.46,7.30$ (H-1 in indenyl / $\mathrm{Zr}-\mathrm{CH}_{3}$, $\mathrm{CH}_{3} \mathrm{CCH}_{\text {front }}, \mathrm{H}-7$ in indenyl).

17-anti $\left(\mathrm{Zr}-\mathrm{CH}_{3}\right.$ is at the opposite side to the cyclobutylene bridge, minor product):

${ }^{1} \mathbf{H}$ NMR $\left(599.7 \mathrm{MHz}, 298 \mathrm{~K}, \mathrm{C}_{6} \mathrm{D}_{5} \mathrm{CD}_{3}\right.$, small amount of $\left.{ }^{t} \mathrm{BuNC}\right): \delta=-0.42(\mathrm{~s}, 3 \mathrm{H}$, $\mathrm{Zr}-\mathrm{CH}_{3}$, the opposite side to the cyclobutylene bridge), 0.63 (s, $9 \mathrm{H},{ }^{t} \mathrm{BuN}=\mathrm{C}-\mathrm{Zr}$ ), 1.21 (s, 6H, $\mathrm{CH}_{3}$ ), 1.77 (AA'BB', 2H, $\mathrm{CH}_{3} \mathrm{CCH}_{\text {back }}$ ), 2.45 (s, 3H, $\mathrm{CH}_{3} \mathrm{C}-\mathrm{Zr}$ ), 2.50 (AA'BB', 2H, $\mathrm{CH}_{3} \mathrm{CCH}_{\text {front }}$ ), $5.88(\mathrm{dd}, \mathrm{J}=2.3 \mathrm{~Hz}, \mathrm{~J}=0.7 \mathrm{~Hz}, 2 \mathrm{H}, \mathrm{H}-3$ in indenyl), 6.10 (dd, $\mathrm{J}=$ $2.3 \mathrm{~Hz}, \mathrm{~J}=0.7 \mathrm{~Hz}, 2 \mathrm{H}, \mathrm{H}-1$ in indenyl, the same side with the cyclobutylene bridge), $6.44(\mathrm{~m}, 2 \mathrm{H}, \mathrm{H}-6$ in indenyl ), $6.59(\mathrm{~m}, 2 \mathrm{H}, \mathrm{H}-7$ in indenyl), $6.65(\mathrm{~m}, 2 \mathrm{H}, \mathrm{H}-5$ in indenyl), 7.33 (m, 2H, H-4 in indenyl).

${ }^{13} \mathrm{C}$ NMR $\left(150.8 \mathrm{MHz}, 298 \mathrm{~K}, \mathrm{C}_{6} \mathrm{D}_{5} \mathrm{CD}_{3}\right.$, small amount of $\left.{ }^{t} \mathrm{BuNC}\right): \delta=19.6\left({\left.\mathrm{Zr}-\mathrm{CH}_{3}\right)}\right.$ $22.4\left(\mathrm{CH}_{3} \mathrm{C}-\mathrm{Zr}\right), 25.4\left(\mathrm{CH}_{3}\right), 31.0\left(\mathrm{CH}_{2}\right), 31.2\left(\mathrm{CH}_{3}\right.$ in $\left.{ }^{t} \mathrm{Bu}\right), 48.2\left(\mathrm{CH}_{3} \mathrm{C}\right), 63.8\left(\mathrm{Me}_{3} \mathrm{C}\right.$ in ${ }^{t} \mathrm{Bu}$ ), 88.9 (C-1 in indenyl, the same side with the cyclobutylene bridge), 93.8 (C-3 in indenyl), 121.9 (C-5 in indenyl ), 122.0 (C-7 in indenyl), 122.7 (C-6 in indenyl), 122.4 (C-7' in indenyl), 124.8 (C-4' in indenyl), 124.9 (C-4 in indenyl), 139.4 (C-2 in indenyl), $234.5(\mathrm{~N}=\mathrm{C}-\mathrm{Zr})$.

${ }^{\mathbf{1}} \mathbf{H},{ }^{\mathbf{1 3}} \mathbf{C}$-GHSQC (599.7 MHz/150.8 MHz, $298 \mathrm{~K}, \mathrm{C}_{6} \mathrm{D}_{5} \mathrm{CD}_{3}$, small amount of $\left.{ }^{t} \mathrm{BuNC}\right)$ : 
$\delta\left({ }^{1} \mathrm{H}\right) / \delta\left({ }^{13} \mathrm{C}\right)=-0.42 / 19.6\left(\mathrm{Zr}-\mathrm{CH}_{3} / \mathrm{Zr}-\mathrm{CH}_{3}\right), 0.63 / 31.2\left({ }^{t} \mathrm{Bu} / \mathrm{CH}_{3}\right.$ in $\left.{ }^{t} \mathrm{Bu}\right), 1.21 /$ $25.4\left(\mathrm{CH}_{3} / \mathrm{CH}_{3}\right), 1.77$ / $31.0\left(\mathrm{CH}_{3} \mathrm{CCH}_{\text {back }} / \mathrm{CH}_{2}\right), 2.45$ / $22.4\left(\mathrm{CH}_{3} \mathrm{C}-\mathrm{Zr} / \mathrm{CH}_{3} \mathrm{C}-\mathrm{Zr}\right)$, 2.50 / $31.0\left(\mathrm{CH}_{3} \mathrm{CCH}_{\text {front }} / \mathrm{CH}_{2}\right), 5.88$ / 93.8 (H-3 in indenyl / C-3 in indenyl), 6.10 / 88.9 (H-1 in indenyl / C-1 in indenyl), 6.44 / 122.7 (H-6 in indenyl / C-6 in indenyl), 6,59 / 122.0 (H-7 in indenyl / C-7 in indenyl), 6.65 / 121.9 (H-5 in indenyl / C-5 in indenyl ), 7.33 / 124.9 (H-4 in indenyl / C-4 in indenyl).

${ }^{\mathbf{1}} \mathbf{H},{ }^{1 \mathbf{1 3}} \mathbf{C}$-GHMBC $\left(599.7 \mathrm{MHz} / 150.8 \mathrm{MHz}, \mathrm{C}_{6} \mathrm{D}_{5} \mathrm{CD}_{3}\right.$, small amount of ${ }^{t} \mathrm{BuNC}$, selected ${ }^{13} \mathrm{C}$ traces $): \delta\left({ }^{13} \mathrm{C}\right) / \delta\left({ }^{1} \mathrm{H}\right)=48.2 / 1.21,1.77,2.50\left(\mathrm{CH}_{3} \mathrm{C} / \mathrm{CH}_{3}\right.$, $\left.\mathrm{CH}_{3} \mathrm{CCH}_{\text {back }}, \mathrm{CH}_{3} \mathrm{CCH}_{\text {front }}\right) ; 63.8 / 0.63\left(\mathrm{Me}_{3} \mathrm{C}\right.$ in $\left.{ }^{t} \mathrm{Bu} /{ }^{t} \mathrm{Bu}\right) ; 122.4$ / 5.88, 6.10, 6.59, 6.65 (C-7' in indenyl / H-3 in indenyl, H-1 in indenyl, H-7 in indenyl, H-5 in indenyl); 124.8 / 5.88, 6.10, 6.59, 6.65 (C-4' in indenyl / H-3 in indenyl, $\mathrm{H}-1$ in indenyl, H-7 in indenyl, H-5 in indenyl); 139.4 / 1.21, 1.77, 2.50, 5.88, 6.10 (C-2 in indenyl / $\mathrm{CH}_{3}$, $\mathrm{CH}_{3} \mathrm{CCH}_{\text {back }}, \mathrm{CH}_{3} \mathrm{CCH}_{\text {front }}, \mathrm{H}-3$ in indenyl, $\mathrm{H}-1$ in indenyl); 234.5 / -0.42, 2.45 $\left(\mathrm{N}=\mathrm{C}-\mathrm{Zr} / \mathrm{Zr}-\mathrm{CH}_{3}, \mathrm{CH}_{3} \mathrm{C}-\mathrm{Zr}\right)$.

${ }^{1} \mathbf{H}\left\{{ }^{1} \mathbf{H}\right\}$-NOE (599.8 MHz, $298 \mathrm{~K}, \mathrm{C}_{6} \mathrm{D}_{5} \mathrm{CD}_{3}$, small amount of $\left.{ }^{t} \mathrm{BuNC}\right): \delta\left({ }^{1} \mathrm{H}\right)_{\text {irradiation }} /$ $\delta\left({ }^{1} \mathrm{H}\right)_{\text {response }}=-0.42 / 0.63,5.88,7.33\left(\mathrm{Zr}-\mathrm{CH}_{3} /{ }^{t} \mathrm{Bu}, \mathrm{H}-3\right.$ in indenyl, H-4 in indenyl $) ;$ $0.63 /-0.42,2.45,6.44,6.59,6.65{ }^{t}{ }^{\mathrm{Bu}} / \mathrm{Zr}-\mathrm{CH}_{3}, \mathrm{CH}_{3} \mathrm{C}-\mathrm{Zr}, \mathrm{H}-6$ in indenyl, $\mathrm{H}-7$ in indenyl, $\mathrm{H}-5$ in indenyl); $1.21 / 1.77,5.88\left(\mathrm{CH}_{3} \mathrm{CCH}_{\text {back }}\right.$, H-3 in indenyl); 2.45 / 0.63, 6.10, $6.59\left(\mathrm{CH}_{3} \mathrm{C}-\mathrm{Zr} /{ }^{t} \mathrm{Bu}, \mathrm{H}-1\right.$ in indenyl, $\mathrm{H}-7$ in indenyl); $5.88 /-0.42,1.21,7.33$ (H-3 in indenyl / $\mathrm{Zr}-\mathrm{CH}_{3}, \mathrm{CH}_{3}, \mathrm{H}-4$ in indenyl); 6.10 / 2.50, 6.59 (H-1 in indenyl / $\mathrm{CH}_{3} \mathrm{CCH}_{\text {front }}$, $\mathrm{H}-7$ in indenyl).

17-syn $\left(\mathrm{Zr}-\mathrm{CH}_{3}\right.$ is at the same side with the cyclobutylene bridge, major product): 
${ }^{1} \mathbf{H}$ NMR (499.8 MHz, 298K, $\left.\mathrm{C}_{6} \mathrm{D}_{6}\right): \delta=0.42\left(\mathrm{~s}, 3 \mathrm{H}, \mathrm{Zr}_{-} \mathrm{CH}_{3}\right), 0.67$ (s, 9H, $\left.{ }^{t} \mathrm{BuN}=\mathrm{C}-\mathrm{Zr}\right), 1.29\left(\mathrm{~s}, 6 \mathrm{H}, \mathrm{CH}_{3}\right), 1.77\left(\mathrm{AA}^{\prime} \mathrm{BB}\right.$ ', $2 \mathrm{H}, \mathrm{CH}_{3} \mathrm{CCH}_{\text {back }}$ ), 2.27 (AA'BB', 3H $\mathrm{CH}_{3} \mathrm{C}-\mathrm{Zr}$ ), 2.53 (AA'BB', 2H CH${ }_{3} \mathrm{CCH}_{\text {front }}$ ), 6.02 (dd, J = 2.3 Hz, J = 0.7 Hz, 2H, H-3 in indenyl), $6.21(\mathrm{dd}, \mathrm{J}=2.3 \mathrm{~Hz}, \mathrm{~J}=0.7 \mathrm{~Hz}, 2 \mathrm{H}, \mathrm{H}-1$ in indenyl, the same side with the cyclobutylene bridge), 6.48 (m, 2H, H-5 in indenyl), 6.59 (m, 2H, H-6 in indenyl ), $6,84(\mathrm{~m}, 2 \mathrm{H}, \mathrm{H}-4$ in indenyl), 7.44 ( $\mathrm{m}, 2 \mathrm{H}, \mathrm{H}-7$ in indenyl).

${ }^{13}$ C NMR (125.7 MHz, 298K, $\left.\mathrm{C}_{6} \mathrm{D}_{6}\right): \delta=14.4\left(\mathrm{Zr}-\mathrm{CH}_{3}\right), 20.8\left(\mathrm{CH}_{3} \mathrm{C}-\mathrm{Zr}\right), 25.8\left(\mathrm{CH}_{3}\right)$, $30.8\left(\mathrm{CH}_{2}\right), 31.4\left(\mathrm{CH}_{3}\right.$ in $\left.{ }^{t} \mathrm{Bu}\right), 48.1\left(\mathrm{CH}_{3} \mathrm{C}\right), 63.8\left(\mathrm{Me}_{3} \mathrm{C}\right.$ in $\left.{ }^{t} \mathrm{Bu}\right), 87.5(\mathrm{C}-3$ in indenyl), 97.6 (C-1 in indenyl, the same side with the cyclobutylene bridge), 121.1 (C-7' in indenyl), 121.5 (C-4 in indenyl), 121.6 (C-6 in indenyl ), 123.0 (C-5 in indenyl), 124.4 (C-7 in indenyl), 125.5 (C-4' in indenyl), 139.6 (C-2 in indenyl), 233.1 (N=C-Zr).

${ }^{\mathbf{1}} \mathbf{H},{ }^{\mathbf{1 3}} \mathbf{C}$-GHSQC $\left(499.8 \mathrm{MHz} / 125.7 \mathrm{MHz}, 298 \mathrm{~K}, \mathrm{C}_{6} \mathrm{D}_{6}\right): \delta\left({ }^{1} \mathrm{H}\right) / \delta\left({ }^{13} \mathrm{C}\right)=0.42 / 14.4$ $\left(\mathrm{Zr}-\mathrm{CH}_{3} / \mathrm{Zr}-\mathrm{CH}_{3}\right), 0.67 / 31.4\left({ }^{t} \mathrm{Bu} / \mathrm{CH}_{3}\right.$ in $\left.{ }^{t} \mathrm{Bu}\right), 1.29 / 25.8\left(\mathrm{CH}_{3} / \mathrm{CH}_{3}\right), 1.77 / 30.8$ $\left(\mathrm{CH}_{3} \mathrm{CCH}_{\text {back }} / \mathrm{CH}_{2}\right), 2.27$ / $20.8\left(\mathrm{CH}_{3} \mathrm{C}-\mathrm{Zr} / \mathrm{CH}_{3} \mathrm{C}-\mathrm{Zr}\right), 2.53 / 30.8\left(\mathrm{CH}_{3} \mathrm{CCH}_{\text {front }}\right.$ / $\left.\mathrm{CH}_{2}\right), 6.02$ / 87.5 (H-3 in indenyl / C-3 in indenyl), 6.21 / 97.6 (H-1 in indenyl / C-1 in indenyl), 6.48 / 123.0 (H-5 in indenyl / C-5 in indenyl), 6.59 / 121.6 (H-6 in indenyl / C-6 in indenyl ), 6,84 / 121.5 (H-4 in indenyl / C-4 in indenyl), 7.44 / 124.4 (H-7 in indenyl / C-7 in indenyl).

${ }^{\mathbf{1}} \mathbf{H},{ }^{\mathbf{1 3}} \mathbf{C}$-GHMBC (499.8 MHz/125.7 MHz, $298 \mathrm{~K}, \mathrm{C}_{6} \mathrm{D}_{6}$, selected ${ }^{13} \mathrm{C}$ traces $): \delta\left({ }^{13} \mathrm{C}\right)$ / $\delta\left({ }^{1} \mathrm{H}\right)=48.1 / 1.29,1.77,2.53\left(\mathrm{CH}_{3} \mathrm{C} / \mathrm{CH}_{3}, \mathrm{CH}_{3} \mathrm{CCH}_{\text {back }}, \mathrm{CH}_{3} \mathrm{CCH}_{\text {front }}\right) ; 63.8 / 0.67$ $\left(\mathrm{Me}_{3} \mathrm{C}\right.$ in $\left.{ }^{t} \mathrm{Bu} /{ }^{t} \mathrm{Bu}\right) ; 121.1 / 6.02,6.21,6.59,6.84(\mathrm{C}-7$ ' in indenyl / H-3 in indenyl, H-1 in indenyl, H-6 in indenyl, H-4 in indenyl); 125.5 / 6.02, 6.21, 6.48, 7.44 (C-4' in 
indenyl / H-3 in indenyl, H-1 in indenyl, H-5 in indenyl, H-7 in indenyl); 139.6 / 1.29, 1.77, 2.53, 6.02, 6.21 (C-2 in indenyl / $\mathrm{CH}_{3}, \mathrm{CH}_{3} \mathrm{CCH}_{\text {back }}, \mathrm{CH}_{3} \mathrm{CCH}_{\text {front }}, \mathrm{H}-3$ in indenyl, $\mathrm{H}-1$ in indenyl); $233.1 / 0.42,2.27\left(\mathrm{~N}=\mathrm{C}-\mathrm{Zr} / \mathrm{Zr}-\mathrm{CH}_{3}, \mathrm{CH}_{3} \mathrm{C}-\mathrm{Zr}\right)$.

${ }^{1} \mathbf{H}\left\{{ }^{1} \mathbf{H}\right\}$-NOE $\left(499.8 \mathrm{MHz}, 298 \mathrm{~K}, \mathrm{C}_{6} \mathrm{D}_{6}\right): \delta\left({ }^{1} \mathrm{H}\right)_{\text {irradiation }} / \delta\left({ }^{1} \mathrm{H}\right)_{\text {response }}=0.42 / 0.67$, 6.21, $7.44\left(\mathrm{Zr}-\mathrm{CH}_{3} /{ }^{t} \mathrm{Bu}, \mathrm{H}-1\right.$ in indenyl, $\mathrm{H}-7$ in indenyl); 0.67 / 0.42, 2.27, 6.48, 6.59, 6.84, $7.44\left({ }^{t} \mathrm{Bu}, \mathrm{Zr}-\mathrm{CH}_{3}, \mathrm{H}-5\right.$ in indenyl, $\mathrm{H}-6$ in indenyl, $\mathrm{H}-4$ in indenyl, $\mathrm{H}-7$ in indenyl); 1.29 / 1.77, $6.02\left(\mathrm{CH}_{3} / \mathrm{CH}_{3} \mathrm{CCH}_{b a c k}, \mathrm{H}-3\right.$ in indenyl $) ; 2.27$ / 0.67, 6.02, 6.84 $\left(\mathrm{CH}_{3} \mathrm{C}-\mathrm{Zr} /{ }^{t} \mathrm{Bu}, \mathrm{H}-3\right.$ in indenyl, H-4 in indenyl); 6.02 / 1.29, 2.27, 6.84 (H-3 in indenyl

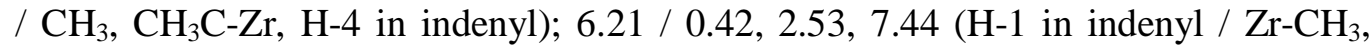
$\mathrm{CH}_{3} \mathrm{CCH}_{\text {front }}, \mathrm{H}-7$ in indenyl); 6.84 / 2.27, 6.02, 6.48 (H-4 in indenyl / $\mathrm{CH}_{3} \mathrm{C}-\mathrm{Zr}, \mathrm{H}-3$ in indenyl, H-5 in indenyl).

17-anti $\left(\mathrm{Zr}-\mathrm{CH}_{3}\right.$ is at the opposite side to the cyclobutylene bridge, minor product): ${ }^{1} \mathrm{H}$ NMR (499.8 MHz, 298K, $\left.\mathrm{C}_{6} \mathrm{D}_{6}\right): \delta=-0.26\left(\mathrm{~s}, 3 \mathrm{H}, \mathrm{Zr}-\mathrm{CH}_{3}\right.$, the opposite side to the cyclobutylene bridge), $0.71\left(\mathrm{~s}, 9 \mathrm{H},{ }^{t} \mathrm{BuN}=\mathrm{C}-\mathrm{Zr}\right), 1.27\left(\mathrm{~s}, 6 \mathrm{H}, \mathrm{CH}_{3}\right), 1.82\left(\mathrm{AA}^{\prime} \mathrm{BB}\right.$ ', $2 \mathrm{H}$, $\mathrm{CH}_{3} \mathrm{CCH}_{\text {back }}$ ), 2.47 (s, 3H, $\left.\mathrm{CH}_{3} \mathrm{C}-\mathrm{Zr}\right), 2.56\left(\mathrm{AA}^{\prime} \mathrm{BB}^{\prime}, 2 \mathrm{H}, \mathrm{CH}_{3} \mathrm{CCH}_{\text {front }}\right), 5.98(\mathrm{dd}, \mathrm{J}=$ $2.3 \mathrm{~Hz}, \mathrm{~J}=0.7 \mathrm{~Hz}, 2 \mathrm{H}, \mathrm{H}-3$ in indenyl), $6.17(\mathrm{dd}, \mathrm{J}=2.3 \mathrm{~Hz}, \mathrm{~J}=0.7 \mathrm{~Hz}, 2 \mathrm{H}, \mathrm{H}-1$ in indenyl, the same side with the cyclobutylene bridge), 6.53 (m, 2H, H-6 in indenyl ), $6.67(\mathrm{~m}, 2 \mathrm{H}, \mathrm{H}-7$ in indenyl), $6.76(\mathrm{~m}, 2 \mathrm{H}, \mathrm{H}-5$ in indenyl), $7.47(\mathrm{~m}, 2 \mathrm{H}, \mathrm{H}-4$ in indenyl).

${ }^{13} \mathrm{C}$ NMR $\left(125.7 \mathrm{MHz}, 298 \mathrm{~K}, \mathrm{C}_{6} \mathrm{D}_{6}\right): \delta=19.6\left(\mathrm{Zr}-\mathrm{CH}_{3}\right), 22.5\left(\mathrm{CH}_{3} \mathrm{C}-\mathrm{Zr}\right), 25.5\left(\mathrm{CH}_{3}\right)$, 31.0 $\left(\mathrm{CH}_{2}\right), 31.2\left(\mathrm{CH}_{3}\right.$ in $\left.{ }^{t} \mathrm{Bu}\right), 48.2\left(\mathrm{CH}_{3} \mathrm{C}\right), 63.7\left(\mathrm{Me}_{3} \mathrm{C}\right.$ in $\left.{ }^{t} \mathrm{Bu}\right), 88.9(\mathrm{C}-1$ in indenyl, the same side with the cyclobutylene bridge), 93.8 (C-3 in indenyl), 121.9 (C-5 in 
indenyl ), 122.0 (C-7 in indenyl), 122.7 (C-6 in indenyl), 122.4 (C-7' in indenyl), 124.8 (C-4' in indenyl), 124.9 (C-4 in indenyl), 139.4 (C-2 in indenyl), 234.5 (N=C-Zr).

${ }^{\mathbf{1}} \mathbf{H},{ }^{\mathbf{1 3}} \mathbf{C}-\mathbf{G H S Q C}\left(499.8 \mathrm{MHz} / 125.7 \mathrm{MHz}, 298 \mathrm{~K}, \mathrm{C}_{6} \mathrm{D}_{6}\right): \delta\left({ }^{1} \mathrm{H}\right) / \delta\left({ }^{13} \mathrm{C}\right)=-0.26 /$ $19.6\left(\mathrm{Zr}-\mathrm{CH}_{3} / \mathrm{Zr}-\mathrm{CH}_{3}\right), 0.71 / 31.2\left({ }^{t} \mathrm{Bu} / \mathrm{CH}_{3}\right.$ in $\left.{ }^{t} \mathrm{Bu}\right), 1.27 / 25.5\left(\mathrm{CH}_{3} / \mathrm{CH}_{3}\right), 1.82$ / $31.0\left(\mathrm{CH}_{3} \mathrm{CCH}_{\text {back }} / \mathrm{CH}_{2}\right), 2.47$ / $22.5\left(\mathrm{CH}_{3} \mathrm{C}-\mathrm{Zr} / \mathrm{CH}_{3} \mathrm{C}-\mathrm{Zr}\right), 2.56 / 31.0\left(\mathrm{CH}_{3} \mathrm{CCH}_{\text {front }} /\right.$ $\mathrm{CH}_{2}$ ), 5.98 / 93.8 (H-3 in indenyl / C-3 in indenyl), 6.17 / 88.9 (H-1 in indenyl / C-1 in indenyl), 6.53 / 122.7 (H-6 in indenyl / C-6 in indenyl), 6.67 / 122.0 (H-7 in indenyl / C-7 in indenyl), 6.76 / 121.9 (H-5 in indenyl / C-5 in indenyl ), 7.47 / 124.9 (H-4 in indenyl / C-4 in indenyl).

${ }^{\mathbf{1}} \mathbf{H},{ }^{\mathbf{1 3}} \mathbf{C}$-GHMBC (499.8 MHz / $125.7 \mathrm{MHz}, 298 \mathrm{~K}, \mathrm{C}_{6} \mathrm{D}_{6}$, selected ${ }^{13} \mathrm{C}$ traces $): \delta\left({ }^{13} \mathrm{C}\right)$ $/ \delta\left({ }^{1} \mathrm{H}\right)=48.2 / 1.27,1.82,2.56\left(\mathrm{CH}_{3} \mathrm{C} / \mathrm{CH}_{3}, \mathrm{CH}_{3} \mathrm{CCH}_{\text {back }}, \mathrm{CH}_{3} \mathrm{CCH}_{\text {front }}\right) ; 63.7 / 0.71$ $\left(\mathrm{Me}_{3} \mathrm{C}\right.$ in $\left.{ }^{t} \mathrm{Bu} /{ }^{t} \mathrm{Bu}\right) ; 122.4 / 5.98,6.17,6.53,7.47$ (C-7' in indenyl / H-3 in indenyl, H-1 in indenyl, H-6 in indenyl, H-4 in indenyl); 124.8 / 5.98, 6.17, 6.67, 6.76 (C-4' in indenyl / H-3 in indenyl, H-1 in indenyl, H-7 in indenyl, H-5 in indenyl); 139.4 / 1.27, 1.82, 2.56, 5.98, 6.17 (C-2 in indenyl / $\mathrm{CH}_{3}, \mathrm{CH}_{3} \mathrm{CCH}_{\text {back }}, \mathrm{CH}_{3} \mathrm{CCH}_{\text {front }}, \mathrm{H}-3$ in indenyl, $\mathrm{H}-1$ in indenyl), $234.5 /-0.26,2.47$ (N=C-Zr / $\left.\mathrm{Zr}-\mathrm{CH}_{3}, \mathrm{CH}_{3} \mathrm{C}-\mathrm{Zr}\right)$.

${ }^{1} \mathbf{H}\left\{{ }^{1} \mathbf{H}\right\}$-NOE $\left(499.8 \mathrm{MHz}, 298 \mathrm{~K}, \mathrm{C}_{6} \mathrm{D}_{6}\right): \delta\left({ }^{1} \mathrm{H}\right)_{\text {irradiation }} / \delta\left({ }^{1} \mathrm{H}\right)_{\text {response }}=-0.26 / 0.71$, 5.98, $7.47\left(\mathrm{Zr}-\mathrm{CH}_{3} /{ }^{t} \mathrm{Bu}, \mathrm{H}-3\right.$ in indenyl, H-4 in indenyl); $0.71 /-0.26,2.47,6.53,6.67$, $6.76\left({ }^{t} \mathrm{Bu} / \mathrm{Zr}-\mathrm{CH}_{3}, \mathrm{CH}_{3} \mathrm{C}-\mathrm{Zr}, \mathrm{H}-6\right.$ in indenyl, H-7 in indenyl, H-5 in indenyl); 1.27 / 1.82, $5.98\left(\mathrm{CH}_{3} / \mathrm{CH}_{3} \mathrm{CCH}_{\text {back }}, \mathrm{H}-3\right.$ in indenyl $) ; 2.47 / 0.71,6.17,6.67\left(\mathrm{CH}_{3} \mathrm{C}-\mathrm{Zr} /{ }^{t} \mathrm{Bu}\right.$, $\mathrm{H}-1$ in indenyl, $\mathrm{H}-7$ in indenyl); 5.98 / -0.26, 1.27, 7.47 (H-3 in indenyl / $\mathrm{Zr}-\mathrm{CH}_{3}, \mathrm{CH}_{3}$, $\mathrm{H}-4$ in indenyl); 6.17 / 2.47, 2.56, 6.67 (H-1 in indenyl / $\mathrm{CH}_{3} \mathrm{C}-\mathrm{Zr}, \mathrm{CH}_{3} \mathrm{CCH}_{\text {front }}, \mathrm{H}-7$ in 
indenyl); 6.67 / 0.71, 2.47, 6.17, 6.53 (H-7 in indenyl / ${ }^{t} \mathrm{BuN}=\mathrm{C}-\mathrm{Zr}, \mathrm{CH}_{3} \mathrm{C}-\mathrm{Zr}, \mathrm{H}-1$ in indenyl, 6-H in indenyl).

\section{$\eta^{2}$-Benzoyl phenyl ansa-bisindenyl zirconium complexes 18}

The X-ray data of complexes 18 shows that 18 -anti is the major product (18-anti : 18 -syn $=55: 45)$ and we also measured the NMR data of the crystals in toluene- $d_{8}$ at $298 \mathrm{~K}$, the ratio between major product and minor one is ca. $57: 43$ (determined by ${ }^{1} \mathrm{H}$ NMR), which is consistent with the X-ray data. NMR data below comes from non-crystal sample in toluene- $d_{8}$ at $298 \mathrm{~K}$. The ratio between the major product (18-anti) and the minor one(18-syn) is ca. $56: 44$ (determined by ${ }^{1} \mathrm{H}$ NMR).

18-syn ( $\mathrm{Zr}-\mathrm{Ph}$ is at the same side with the cyclobutylene bridge, minor product):

${ }^{1} \mathbf{H}$ NMR $\left(599.7 \mathrm{MHz}, 298 \mathrm{~K}, \mathrm{C}_{6} \mathrm{D}_{5} \mathrm{CD}_{3}\right): \delta 1.29\left(\mathrm{~s}, 6 \mathrm{H}, \mathrm{CH}_{3}\right), 1.81$ (AA'BB', 2H, $\mathrm{CH}_{3} \mathrm{CCH}_{\text {back }}$ ), 2.68 (AA'BB', 2H, $\mathrm{CH}_{3} \mathrm{CCH}_{\text {front }}$ ), 6.24 (m, 2H, H-3 in indenyl), 6.53 (m, $2 \mathrm{H}, \mathrm{H}-1$ in indenyl, the same side with the cyclobutylene bridge $), 7.30(\mathrm{~m}, 1 \mathrm{H}, p-\mathrm{H}$ in Ph-Zr), 7.42 (m, 2H, $m$-H in $\mathrm{Ph}-\mathrm{Zr}$ ), 7.23 (m, 2H, $m-\mathrm{H}$ in $\mathrm{PhC}-\mathrm{Zr}), 7.25$ (m, 1H, $p$-H in PhC-Zr), 7.98 (m, 2H, $o-\mathrm{H}$ in $\mathrm{PhC}-\mathrm{Zr}), 8.25$ (d, J =6.6 Hz, 2H, $o-\mathrm{H}$ in $\mathrm{Ph}-\mathrm{Zr}$ ).

${ }^{13}$ C NMR $\left(150.8 \mathrm{MHz}, 298 \mathrm{~K}, \mathrm{C}_{6} \mathrm{D}_{5} \mathrm{CD}_{3}\right): \delta 25.6\left(\mathrm{CH}_{3}\right), 31.0\left(\mathrm{CH}_{2}\right), 49.1\left(\mathrm{CH}_{3} \mathrm{C}\right), 89.8$ (C-3 in indenyl), 98.6 (C-1 in indenyl), 124.5 ( $p-\mathrm{C}$ in $\mathrm{Ph}-\mathrm{Zr}), 126.4(m-\mathrm{C}$ in $\mathrm{PhC}-\mathrm{Zr})$, 126.5 ( $m$-C in $\mathrm{Ph}-\mathrm{Zr}$ ), 131.3 (o-C in $\mathrm{PhC}-\mathrm{Zr}$ ), 140.3 (o-C in $\mathrm{Ph}-\mathrm{Zr}$ ), 140.8 (C-2 in indenyl), 180.6 (Zr-C in Ph-Zr), 298.9 (Zr-C=O).

${ }^{\mathbf{1}} \mathbf{H},{ }^{\mathbf{1 3}} \mathbf{C}$-GHSQC $\left(599.7 \mathrm{MHz} / 150.8 \mathrm{MHz}, 298 \mathrm{~K}, \mathrm{C}_{6} \mathrm{D}_{6}\right): \delta\left({ }^{1} \mathrm{H}\right) / \delta\left({ }^{13} \mathrm{C}\right)=1.29 / 25.6$ $\left(\mathrm{CH}_{3} / \mathrm{CH}_{3}\right) ; 1.81 / 31.0\left(\mathrm{CH}_{3} \mathrm{CCH}_{\text {back }} / \mathrm{CH}_{2}\right) ; 2.68$ / $31.0\left(\mathrm{CH}_{3} \mathrm{CCH}_{\text {front }} / \mathrm{CH}_{2}\right) ; 6.24$ / 89.8 (H-3 in indenyl / C-3 in indenyl), 6.53 / 98.6 (H-1 in indenyl / C-1 in indenyl), 
7.30 / 124.5 ( $p-\mathrm{H}$ in $\mathrm{Ph}-\mathrm{Zr} / p-\mathrm{C}$ in $\mathrm{Ph}-\mathrm{Zr}), 7.42$ / 126.5 ( $m-\mathrm{H}$ in $\mathrm{Ph}-\mathrm{Zr} / m-\mathrm{C}$ in $\mathrm{Ph}-\mathrm{Zr}$ ), $7.23 / 126.4(m-\mathrm{H}$ in $\mathrm{PhC}-\mathrm{Zr} / m-\mathrm{C}$ in $\mathrm{PhC}-\mathrm{Zr}), 7.98 / 131.3(o-\mathrm{H}$ in $\mathrm{PhC}-\mathrm{Zr} / o-\mathrm{C}$ in $\mathrm{PhC}-\mathrm{Zr}$ ), 8.25 / 140.3 (o-H in $\mathrm{Ph}-\mathrm{Zr} / o-\mathrm{C}$ in $\mathrm{Ph}-\mathrm{Zr}$ ).

${ }^{\mathbf{1}} \mathbf{H},{ }^{\mathbf{1 3}} \mathbf{C}$-GHMBC (599.7 MHz/150.8 MHz, $298 \mathrm{~K}, \mathrm{C}_{6} \mathrm{D}_{6}$, selected ${ }^{13} \mathrm{C}$ traces $): \delta\left({ }^{13} \mathrm{C}\right)$ $/ \delta\left({ }^{1} \mathrm{H}\right)=49.1 / 1.29,1.81,2.68,6.24,6.53\left(\mathrm{CH}_{3} \mathrm{C} / \mathrm{CH}_{3}, \mathrm{CH}_{3} \mathrm{CCH}_{\text {back }}, \mathrm{CH}_{3} \mathrm{CCH}_{\text {front }}\right.$, $\mathrm{H}-3$ in indenyl, $\mathrm{H}-1$ in indenyl); 124.5 / 8.25 ( $p$-C in $\mathrm{Ph}-\mathrm{Zr} / o-\mathrm{H}$ in $\mathrm{Ph}-\mathrm{Zr}) ; 140.3$ / 7.30 (o-C in $\mathrm{Ph}-\mathrm{Zr} / p$-H in Ph-Zr); 140.8 / 1.29, 1.81, 2.68, 6.24, 6.53 (C-2 in indenyl / $\mathrm{CH}_{3}$, $\mathrm{CH}_{3} \mathrm{CCH}_{\text {back }}, \mathrm{CH}_{3} \mathrm{CCH}_{\text {front }}$, H-3 in indenyl, $\mathrm{H}-1$ in indenyl); 180.6 / 7.42, 8.25 (Zr-C in $\mathrm{Ph}-\mathrm{Zr} / m-\mathrm{H}$ in $\mathrm{Ph}-\mathrm{Zr}, o-\mathrm{H}$ in $\mathrm{Ph}-\mathrm{Zr}) ; 298.9 / 7.98$ (Zr-C=O / $o-\mathrm{H}$ in $\mathrm{PhC}-\mathrm{Zr})$.

${ }^{1} \mathbf{H}\left\{{ }^{1} \mathbf{H}\right\}$-TOCSY (599.7 MHz, $298 \mathrm{~K}, \mathrm{C}_{6} \mathrm{D}_{6}$, selected experiments): $\delta\left({ }^{1} \mathrm{H}\right)$ irradiation $/ \delta$ $\left({ }^{1} \mathrm{H}\right)_{\text {response }}=7.42$ / 8.25, 7.30 (m-H in $\mathrm{Ph}-\mathrm{Zr} / o-\mathrm{H}$ in $\mathrm{Ph}-\mathrm{Zr}, p-\mathrm{H}$ in $\left.\mathrm{Ph}-\mathrm{Zr}\right) ; 7.98$ / 7.23, 7.25 (o-H in $\mathrm{PhC}-\mathrm{Zr} / m-\mathrm{H}$ in $\mathrm{PhC}-\mathrm{Zr}, p-\mathrm{H}$ in $\mathrm{PhC}-\mathrm{Zr}$ ); 8.25 / 7.42, 7.30 (o-H in $\mathrm{Ph}-\mathrm{Zr}$ / $m-\mathrm{H}$ in $\mathrm{Ph}-\mathrm{Zr}, p-\mathrm{H}$ in $\mathrm{Ph}-\mathrm{Zr})$.

${ }^{1} \mathbf{H}\left\{{ }^{1} \mathbf{H}\right\}$-NOE $\left(599.7 \mathrm{MHz}, 298 \mathrm{~K}, \mathrm{C}_{6} \mathrm{D}_{6}\right): \delta\left({ }^{1} \mathrm{H}\right)_{\text {irradiation }} / \delta\left({ }^{1} \mathrm{H}\right)_{\text {response }}=1.29 / 1.81$, $6.24\left(\mathrm{CH}_{3} / \mathrm{CH}_{3} \mathrm{CCH}_{\text {back }}, \mathrm{H}-3\right.$ in indenyl $) ; 2.68 / 1.81,6.53,8.25\left(\mathrm{CH}_{3} \mathrm{CCH}_{\text {front }} /\right.$ $\mathrm{CH}_{3} \mathrm{CCH}_{\text {back }}, \mathrm{H}-1$ in indenyl, $o-\mathrm{H}$ in $\left.\mathrm{Ph}-\mathrm{Zr}\right) ; 7.42$ / 7.30, $8.25(m-\mathrm{H}$ in $\mathrm{Ph}-\mathrm{Zr} / p-\mathrm{H}$ in $\mathrm{Ph}-\mathrm{Zr}, o-\mathrm{H}$ in $\mathrm{Ph}-\mathrm{Zr}) ; 7.98 / 6.24,7.23(o-\mathrm{H}$ in $\mathrm{PhC}-\mathrm{Zr} / \mathrm{H}-3$ in indenyl, $m-\mathrm{H}$ in PhC-Zr); 8.25 / 2.68, 6.53, $7.42\left(o-\mathrm{H}\right.$ in $\mathrm{Ph}-\mathrm{Zr} / \mathrm{CH}_{3} \mathrm{CCH}_{\text {front }}, \mathrm{H}-1$ in indenyl, $m-\mathrm{H}$ in $\mathrm{Ph}-\mathrm{Zr})$.

18-anti ( $\mathrm{Zr}-\mathrm{Ph}$ is at the opposite side to the cyclobutylene bridge, major product):

${ }^{1} \mathbf{H}$ NMR $\left(599.7 \mathrm{MHz}, 298 \mathrm{~K}, \mathrm{C}_{6} \mathrm{D}_{5} \mathrm{CD}_{3}\right): \delta 1.30\left(\mathrm{~s}, 6 \mathrm{H}, \mathrm{CH}_{3}\right), 1.80\left(\mathrm{AA}^{\prime} \mathrm{BB}\right.$ ', 2H, $\mathrm{CH}_{3} \mathrm{CCH}_{\text {back }}$ ), 2.56 (AA'BB', 2H, $\left.\mathrm{CH}_{3} \mathrm{CCH}_{\text {front }}\right), 6.35(\mathrm{~d}, \mathrm{~J}=2.3 \mathrm{~Hz}, 2 \mathrm{H}, \mathrm{H}-3$ in 
indenyl), 6.48 (dd, $\mathrm{J}=2.3 \mathrm{~Hz}, \mathrm{~J}=0.7 \mathrm{~Hz}, 2 \mathrm{H}, \mathrm{H}-1$ in indenyl, the same side with the cyclobutylene bridge), 7.25 (m, 1H, p-H in $\mathrm{Ph}-\mathrm{Zr}), 7.26$ (m, 1H, p-H in PhC-Zr), 7.27 (m, 2H, $m-\mathrm{H}$ in $\mathrm{PhC}-\mathrm{Zr}), 7.36(\mathrm{~m}, 2 \mathrm{H} m-\mathrm{H}$ in $\mathrm{Ph}-\mathrm{Zr}), 8.07(\mathrm{~m}, 2 \mathrm{H}, o-\mathrm{H}$ in $\mathrm{PhC}-\mathrm{Zr})$, 8.09 (b, $2 \mathrm{H} o-\mathrm{H}$ in $\mathrm{Ph}-\mathrm{Zr}$ ).

${ }^{13}$ C NMR (150.8 MHz, 298K, $\left.\mathrm{C}_{6} \mathrm{D}_{5} \mathrm{CD}_{3}\right): \delta 25.0\left(\mathrm{CH}_{3}\right), 31.0\left(\mathrm{CH}_{2}\right), 49.1\left(\mathrm{CH}_{3} \mathrm{C}\right), 90.6$ (C-1 in indenyl), 96.7 (C-3 in indenyl), 124.4 ( $p-\mathrm{C}$ in Ph-Zr), 126.5 ( $m-\mathrm{C}$ in $\mathrm{Ph}-\mathrm{Zr}$ ), 131.2 (o-C in PhC-Zr), 139.9 (o-C in Ph-Zr), 140.5 (C-2 in indenyl), 181.3 (Zr-C in $\mathrm{Ph}-\mathrm{Zr}), 300.8(\mathrm{Zr}-\mathrm{C}=\mathrm{O})$.

${ }^{1} \mathbf{H},{ }^{13}$ C-GHSQC $\left(599.7 \mathrm{MHz} / 150.8 \mathrm{MHz}, 298 \mathrm{~K}, \mathrm{C}_{6} \mathrm{D}_{6}\right): \delta\left({ }^{1} \mathrm{H}\right) / \delta\left({ }^{13} \mathrm{C}\right)=1.30 / 25.0$ $\left(\mathrm{CH}_{3} / \mathrm{CH}_{3}\right), 1.80$ / $31.0\left(\mathrm{CH}_{3} \mathrm{CCH}_{\text {back }} / \mathrm{CH}_{2}\right), 2.56$ / $31.0\left(\mathrm{CH}_{3} \mathrm{CCH}_{\text {front }} / \mathrm{CH}_{2}\right), 6.35$ / 96.7 (H-3 in indenyl / C-3 in indenyl), 6.48 / 90.6 (H-1 in indenyl / C-1 in indenyl), 7.25 / 124.4 ( $p-\mathrm{H}$ in $\mathrm{Ph}-\mathrm{Zr} / p-\mathrm{C}$ in $\mathrm{Ph}-\mathrm{Zr}), 7.36 / 126.5$ ( $m-\mathrm{H}$ in $\mathrm{Ph}-\mathrm{Zr} / m-\mathrm{C}$ in $\mathrm{Ph}-\mathrm{Zr})$, $8.07 / 131.2(o-\mathrm{H}$ in $\mathrm{PhC}-\mathrm{Zr} / o-\mathrm{C}$ in $\mathrm{PhC}-\mathrm{Zr}), 8.09$ / $139.9(o-\mathrm{H}$ in $\mathrm{Ph}-\mathrm{Zr} / o-\mathrm{C}$ in $\mathrm{Ph}-\mathrm{Zr})$.

${ }^{\mathbf{1}} \mathbf{H},{ }^{\mathbf{1 3}} \mathbf{C}-\mathbf{G H M B C}\left(599.7 \mathrm{MHz} / 150.8 \mathrm{MHz}, 298 \mathrm{~K}, \mathrm{C}_{6} \mathrm{D}_{6}\right.$, selected ${ }^{13} \mathrm{C}$ traces $): \delta\left({ }^{13} \mathrm{C}\right)$ / $\delta\left({ }^{1} \mathrm{H}\right)=49.1 / 1.30,1.80,2.56,6.35,6.48\left(\mathrm{CH}_{3} \mathrm{C} / \mathrm{CH}_{3}, \mathrm{CH}_{3} \mathrm{CCH}_{\text {back }}, \mathrm{CH}_{3} \mathrm{CCH}_{\text {front }}\right.$, H-3 in indenyl, H-1 in indenyl); 139.9 / 7.25 ( $o-\mathrm{C}$ in $\mathrm{Ph}-\mathrm{Zr} / p-\mathrm{H}$ in $\mathrm{Ph}-\mathrm{Zr}$ ); 140.5 / 1.30, 1.80, 2.56, 6.35, 6.48 (C-2 in indenyl / $\mathrm{CH}_{3}, \mathrm{CH}_{3} \mathrm{CCH}_{\text {back }}, \mathrm{CH}_{3} \mathrm{CCH}_{\text {front }}, \mathrm{H}-3$ in indenyl, $\mathrm{H}-1$ in indenyl); 181.3 / 7.36 (Zr-C in $\mathrm{Ph}-\mathrm{Zr} / \mathrm{m}-\mathrm{H}$ in $\mathrm{Ph}-\mathrm{Zr}) ; 300.8 / 8.07$ (Zr-C=O / $o-\mathrm{H}$ in $\mathrm{PhC}-\mathrm{Zr})$.

${ }^{1} \mathbf{H}\left\{{ }^{1} \mathbf{H}\right\}$-TOCSY $\left(599.7 \mathrm{MHz}, 298 \mathrm{~K}, \mathrm{C}_{6} \mathrm{D}_{6}\right.$, selected experiments): $\delta\left({ }^{1} \mathrm{H}\right)_{\text {irradiation }} / \delta$ $\left({ }^{1} \mathrm{H}\right)_{\text {response }}=8.07$ / 7.26, $7.27(o-\mathrm{H}$ in $\mathrm{PhC}-\mathrm{Zr} / p-\mathrm{H}$ in $\mathrm{PhC}-\mathrm{Zr}, m-\mathrm{H}$ in $\mathrm{PhC}-\mathrm{Zr}) ; 7.36 /$ 
7.25, 8.09 ( $m-\mathrm{H}$ in $\mathrm{Ph}-\mathrm{Zr} / p-\mathrm{H}$ in $\mathrm{Ph}-\mathrm{Zr}, o-\mathrm{H}$ in $\mathrm{Ph}-\mathrm{Zr}$ ).

${ }^{1} \mathbf{H}\left\{{ }^{1} \mathbf{H}\right\}$-NOE $\left(599.7 \mathrm{MHz}, 298 \mathrm{~K}, \mathrm{C}_{6} \mathrm{D}_{6}\right): \delta\left({ }^{1} \mathrm{H}\right)_{\text {irradiation }} / \delta\left({ }^{1} \mathrm{H}\right)_{\text {response }}=1.30 / 1.80$, $6.35\left(\mathrm{CH}_{3} / \mathrm{CH}_{3} \mathrm{CCH}_{\text {back }}, \mathrm{H}-3\right.$ in indenyl $) ; 2.56 / 1.80,6.48\left(\mathrm{CH}_{3} \mathrm{CCH}_{\text {front }}\right.$ / $\mathrm{CH}_{3} \mathrm{CCH}_{b a c k}, \mathrm{H}-1$ in indenyl); 6.35 / 1.30, 8.09 (H-3 in indenyl / $\mathrm{CH}_{3}, o-\mathrm{H}$ in $\mathrm{Ph}-\mathrm{Zr}$ ); 6.48 / 2.56, 8.07 (H-1 in indenyl / $\mathrm{CH}_{3} \mathrm{CCH}_{\text {front }}, o-\mathrm{H}$ in $\left.\mathrm{PhC}-\mathrm{Zr}\right) ; 7.36 / 7.25,8.09(m-\mathrm{H}$ in $\mathrm{Ph}-\mathrm{Zr} / p-\mathrm{H}$ in $\mathrm{Ph}-\mathrm{Zr}$, $o-\mathrm{H}$ in $\mathrm{Ph}-\mathrm{Zr}) ; 8.07$ / 6.48, 7.27 (o-H in $\mathrm{PhC}-\mathrm{Zr} / \mathrm{H}-1$ in indenyl, $m-\mathrm{H}$ in $\mathrm{PhC}-\mathrm{Zr})$.

All the other ${ }^{1} \mathrm{H}$ NMR signals are within $\delta 7.30-6.00$ as multiplets.

$\eta^{2}$-N-tert-butyliminobenzoyl phenyl ansa-bisindenyl zirconium complexes 19 and 20

19-syn ( $\mathrm{Zr}-\mathrm{Ph}$ is at the same side with the cyclobutylene bridge and the $\mathrm{N}$ atom is outside):

${ }^{1} \mathbf{H}$ NMR $\left(599.7 \mathrm{MHz}, 298 \mathrm{~K}, \mathrm{C}_{6} \mathrm{D}_{5} \mathrm{CD}_{3}\right): \delta=1.31\left(\mathrm{~s}, 9 \mathrm{H},{ }^{t} \mathrm{BuN}=\mathrm{C}-\mathrm{Zr}\right), 1.39(\mathrm{~s}, 6 \mathrm{H}$, $\mathrm{CH}_{3}$ ), 1.80 (AA'BB', 2H, $\mathrm{CH}_{3} \mathrm{CCH}_{\text {back }}$ ), 2.59 (AA'BB', 2H CH $\mathrm{CCH}_{\text {front }}$ ), 6.22 (dd, J $=2.5 \mathrm{~Hz}, \mathrm{~J}=0.7 \mathrm{~Hz}, 2 \mathrm{H}, \mathrm{H}-3$ in indenyl), $6.37(\mathrm{dd}, \mathrm{J}=2.5 \mathrm{~Hz}, \mathrm{~J}=0.7 \mathrm{~Hz}, 2 \mathrm{H}, \mathrm{H}-1$ in indenyl, the same side with the cyclobutylene bridge).

${ }^{13} \mathrm{C}$ NMR $\left(150.8 \mathrm{MHz}, 298 \mathrm{~K}, \mathrm{C}_{6} \mathrm{D}_{5} \mathrm{CD}_{3}\right): \delta=25.0\left(\mathrm{CH}_{3}\right), 31.3\left(\mathrm{CH}_{2}\right), 32.0\left(\mathrm{CH}_{3}\right.$ in $\left.{ }^{t} \mathrm{Bu}\right), 49.3\left(\mathrm{CH}_{3} \mathrm{C}\right), 63.5\left(\mathrm{Me}_{3} \mathrm{C}\right.$ in $\left.{ }^{t} \mathrm{Bu}\right), 89.2(\mathrm{C}-3$ in indenyl), $97.4(\mathrm{C}-1$ in indenyl, the same side with the cyclobutylene bridge), 145.5 (C-2 in indenyl).

${ }^{1} \mathbf{H},{ }^{13} \mathbf{C}$-GHSQC $\left(599.7 \mathrm{MHz} / 150.8 \mathrm{MHz}, 298 \mathrm{~K}, \mathrm{C}_{6} \mathrm{D}_{5} \mathrm{CD}_{3}\right): \delta\left({ }^{1} \mathrm{H}\right) / \delta\left({ }^{13} \mathrm{C}\right)=1.31 /$ $32.0\left({ }^{t} \mathrm{Bu} / \mathrm{CH}_{3}\right.$ in $\left.{ }^{t} \mathrm{Bu}\right), 1.39 / 25.0\left(\mathrm{CH}_{3} / \mathrm{CH}_{3}\right), 1.80 / 31.3\left(\mathrm{CH}_{3} \mathrm{CCH}_{\text {back }} / \mathrm{CH}_{2}\right), 2.59$ / $31.3\left(\mathrm{CH}_{3} \mathrm{CCH}_{\text {front }} / \mathrm{CH}_{2}\right), 6.22$ / $89.2(\mathrm{H}-3$ in indenyl / C-3 in indenyl), 6.37 / 97.4 
(H-1 in indenyl / C-1 in indenyl).

${ }^{\mathbf{1}} \mathbf{H},{ }^{\mathbf{1 3}} \mathbf{C}-\mathbf{G H M B C}\left(599.7 \mathrm{MHz} / 150.8 \mathrm{MHz}, 298 \mathrm{~K}, \mathrm{C}_{6} \mathrm{D}_{5} \mathrm{CD}_{3}\right.$, selected ${ }^{13} \mathrm{C}$ traces): $\delta$ $\left({ }^{13} \mathrm{C}\right) / \delta\left({ }^{1} \mathrm{H}\right)=49.3 / 1.39,1.80,2.59\left(\mathrm{CH}_{3} \mathrm{C} / \mathrm{CH}_{3}, \mathrm{CH}_{3} \mathrm{CCH}_{\text {back }}, \mathrm{CH}_{3} \mathrm{CCH}_{\text {front }}\right) ; 63.5 /$

$1.31\left(\mathrm{Me}_{3} \mathrm{C}\right.$ in $\left.{ }^{t} \mathrm{Bu} /{ }^{t} \mathrm{Bu}\right) ; 145.5 / 1.39,1.80,2.59,6.22,6.37\left(\mathrm{C}-2\right.$ in indenyl / $\mathrm{CH}_{3}$, $\mathrm{CH}_{3} \mathrm{CCH}_{\text {back }}, \mathrm{CH}_{3} \mathrm{CCH}_{\text {front }}, \mathrm{H}-3$ in indenyl, $\mathrm{H}-1$ in indenyl).

${ }^{1} \mathbf{H}\left\{{ }^{1} \mathbf{H}\right\}$-NOE $\left(599.7 \mathrm{MHz}, 298 \mathrm{~K}, \mathrm{C}_{6} \mathrm{D}_{5} \mathrm{CD}_{3}\right): \delta\left({ }^{1} \mathrm{H}\right)_{\text {irradiation }} / \delta\left({ }^{1} \mathrm{H}\right)_{\text {response }}=1.31 /$ $6.22\left({ }^{t} \mathrm{Bu} / \mathrm{H}-3\right.$ in indenyl); 1.39 / 1.80, $6.22\left(\mathrm{CH}_{3} / \mathrm{CH}_{3} \mathrm{CCH}_{b a c k}, \mathrm{H}-3\right.$ in indenyl); 1.80 / 1.39, $2.59\left(\mathrm{CH}_{3} \mathrm{CCH}_{\text {back }} / \mathrm{CH}_{3}, \mathrm{CH}_{3} \mathrm{CCH}_{\text {front }}\right) ; 2.59$ / 1.80, $6.37\left(\mathrm{CH}_{3} \mathrm{CCH}_{\text {front }}\right.$ / $\mathrm{CH}_{3} \mathrm{CCH}_{\text {back }}, \mathrm{H}-1$ in indenyl).

19-anti $(\mathrm{Zr}-\mathrm{Ph}$ is at the opposite side to the cyclobutylene bridge and the $\mathrm{N}$ atom is outside):

${ }^{1} \mathbf{H}$ NMR $\left(599.7 \mathrm{MHz}, 298 \mathrm{~K}, \mathrm{C}_{6} \mathrm{D}_{5} \mathrm{CD}_{3}\right): \delta=1.32\left(\mathrm{~s}, 6 \mathrm{H}, \mathrm{CH}_{3}\right), 1.33(\mathrm{~s}, 9 \mathrm{H}$, ${ }^{t} \mathrm{BuN}=\mathrm{C}-\mathrm{Zr}$ ), $1.92\left(\mathrm{AA}^{\prime} \mathrm{BB} ', 2 \mathrm{H}, \mathrm{CH}_{3} \mathrm{CCH}_{\text {back }}\right), 2.71$ (AA'BB', 2H, $\mathrm{CH}_{3} \mathrm{CCH}_{\text {front }}$ ), $6.08(\mathrm{dd}, \mathrm{J}=2.5 \mathrm{~Hz}, \mathrm{~J}=0.8 \mathrm{~Hz}, 2 \mathrm{H}, \mathrm{H}-3$ in indenyl), $6.34(\mathrm{dd}, \mathrm{J}=2.5 \mathrm{~Hz}, \mathrm{~J}=0.8 \mathrm{~Hz}$ $2 \mathrm{H}, \mathrm{H}-1$ in indenyl, the same side with the cyclobutylene bridge), $6.56(2 \mathrm{H}, \mathrm{H}-4$ in indenyl), 6.86 (2H, H-7 in indenyl).

${ }^{13} \mathrm{C}$ NMR $\left(150.8 \mathrm{MHz}, 298 \mathrm{~K}, \mathrm{C}_{6} \mathrm{D}_{5} \mathrm{CD}_{3}\right): \delta=25.9\left(\mathrm{CH}_{3}\right), 31.4\left(\mathrm{CH}_{2}\right), 31.9\left(\mathrm{CH}_{3}\right.$ in $\left.{ }^{t} \mathrm{Bu}\right), 50.0\left(\mathrm{CH}_{3} \mathrm{C}\right), 63.5\left(\mathrm{Me}_{3} \mathrm{C}\right.$ in $\left.{ }^{t} \mathrm{Bu}\right), 89.7(\mathrm{C}-1$ in indenyl, the same side with the cyclobutylene bridge), 96.0 (C-3 in indenyl), 145.6 (C-2 in indenyl).

${ }^{\mathbf{1}} \mathbf{H},{ }^{\mathbf{1 3}} \mathbf{C}$-GHSQC $\left(599.7 \mathrm{MHz} / 150.8 \mathrm{MHz}, 298 \mathrm{~K}, \mathrm{C}_{6} \mathrm{D}_{5} \mathrm{CD}_{3}\right): \delta\left({ }^{1} \mathrm{H}\right) / \delta\left({ }^{13} \mathrm{C}\right)=1.32 /$ $25.9\left(\mathrm{CH}_{3} / \mathrm{CH}_{3}\right), 1.33 / 31.9\left({ }^{t} \mathrm{Bu} / \mathrm{CH}_{3}\right.$ in $\left.{ }^{t} \mathrm{Bu}\right), 1.92 / 31.4\left(\mathrm{CH}_{3} \mathrm{CCH}_{\text {back }} / \mathrm{CH}_{2}\right), 2.71 /$ $31.4\left(\mathrm{CH}_{3} \mathrm{CCH}_{\text {front }} / \mathrm{CH}_{2}\right), 6.08$ / $96.0(\mathrm{H}-3$ in indenyl / C-3 in indenyl), 6.34 / 89.7 
(H-1 in indenyl / C-1 in indenyl).

${ }^{\mathbf{1}} \mathbf{H},{ }^{\mathbf{1 3}} \mathbf{C - G H M B C}\left(599.7 \mathrm{MHz} / 150.8 \mathrm{MHz}, 298 \mathrm{~K}, \mathrm{C}_{6} \mathrm{D}_{5} \mathrm{CD}_{3}\right.$, selected ${ }^{13} \mathrm{C}$ traces ): $\delta$ $\left({ }^{13} \mathrm{C}\right) / \delta\left({ }^{1} \mathrm{H}\right)=50.0 / 1.32,1.92,2.71\left(\mathrm{CH}_{3} \mathrm{C} / \mathrm{CH}_{3}, \mathrm{CH}_{3} \mathrm{CCH}_{\text {back }}, \mathrm{CH}_{3} \mathrm{CCH}_{\text {front }}\right) ; 63.5 /$

$1.33\left(\mathrm{Me}_{3} \mathrm{C}\right.$ in $\left.{ }^{t} \mathrm{Bu} /{ }^{t} \mathrm{Bu}\right) ; 145.6 / 1.32,1.92,2.71,6.08,6.34\left(\mathrm{C}-2\right.$ in indenyl / $\mathrm{CH}_{3}$, $\mathrm{CH}_{3} \mathrm{CCH}_{\text {back }}, \mathrm{CH}_{3} \mathrm{CCH}_{\text {front }}$, $\mathrm{H}-3$ in indenyl, $\mathrm{H}-1$ in indenyl).

${ }^{1} \mathbf{H}\left\{{ }^{1} \mathbf{H}\right\}$-NOE $\left(599.7 \mathrm{MHz}, 298 \mathrm{~K}, \mathrm{C}_{6} \mathrm{D}_{5} \mathrm{CD}_{3}\right): \delta\left({ }^{1} \mathrm{H}\right)_{\text {irradiation }} / \delta\left({ }^{1} \mathrm{H}\right)_{\text {response }}=1.32 /$ 1.92, $6.08\left(\mathrm{CH}_{3} / \mathrm{CH}_{3} \mathrm{CCH}_{\text {back }}, \mathrm{H}-3\right.$ in indenyl); 1.33 / 6.34 ( ${ }^{t} \mathrm{Bu} / \mathrm{H}-1$ in indenyl); 1.92 / 1.32, $2.71\left(\mathrm{CH}_{3} \mathrm{CCH}_{\text {back }} / \mathrm{CH}_{3}, \mathrm{CH}_{3} \mathrm{CCH}_{\text {front }}\right) ; 2.71$ / 1.92, $6.34\left(\mathrm{CH}_{3} \mathrm{CCH}_{\text {front }}\right.$ / $\mathrm{CH}_{3} \mathrm{CCH}_{\text {back }}, \mathrm{H}-1$ in indenyl); 6.08 / 1.32, 6.56 (H-3 in indenyl / $\mathrm{CH}_{3}, \mathrm{H}-4$ in indenyl). 20-syn ( $\mathrm{Zr}-\mathrm{Ph}$ is at the same side with the cyclobutylene bridge and the $\mathrm{N}$ atom is inside):

${ }^{1} \mathrm{H}$ NMR $\left(599.7 \mathrm{MHz}, 298 \mathrm{~K}, \mathrm{C}_{6} \mathrm{D}_{5} \mathrm{CD}_{3}\right): \delta=0.68\left(\mathrm{~s}, 9 \mathrm{H},{ }^{t} \mathrm{BuN}=\mathrm{C}-\mathrm{Zr}\right), 1.12(\mathrm{~s}, 6 \mathrm{H}$, $\mathrm{CH}_{3}$ ), 1.68 (AA'BB', 2H, $\mathrm{CH}_{3} \mathrm{CCH}_{\text {back }}$ ), 2.48 (AA'BB', 2H, $\left.\mathrm{CH}_{3} \mathrm{CCH}_{\text {front }}\right), 6.10$ (dd, J $=2.3 \mathrm{~Hz}, \mathrm{~J}=0.7 \mathrm{~Hz}, 2 \mathrm{H}, \mathrm{H}-3$ in indenyl), $6.35(\mathrm{dd}, \mathrm{J}=2.3 \mathrm{~Hz}, \mathrm{~J}=0.7 \mathrm{~Hz}, 2 \mathrm{H}, \mathrm{H}-1$ in indenyl, the same side with the cyclobutylene bridge), 6.87 (2H, H-4 in indenyl), 7.06 (2H, H-7 in indenyl), 7.09 (m, 1H, p-H in PhC-Zr), 7.19 (m, 1H, p-H in $\mathrm{Ph}-\mathrm{Zr}), 7.25$ (m, 2H, $m-\mathrm{H}$ in $\mathrm{Ph}-\mathrm{Zr}), 7.29$ (m, 2H, $m-\mathrm{H}$ in $\mathrm{PhC}-\mathrm{Zr}), 7.44$ (m, 2H, $o-\mathrm{H}$ in $\mathrm{PhC}-\mathrm{Zr}$ ), 7.82 (m, 2H, $o-\mathrm{H}$ in $\mathrm{Ph}-\mathrm{Zr}$ ).

${ }^{13} \mathbf{C}$ NMR $\left(150.8 \mathrm{MHz}, 298 \mathrm{~K}, \mathrm{C}_{6} \mathrm{D}_{5} \mathrm{CD}_{3}\right): \delta=25.0\left(\mathrm{CH}_{3}\right), 31.1\left(\mathrm{CH}_{2}\right), 31.8\left(\mathrm{CH}_{3}\right.$ in $\left.{ }^{t} \mathrm{Bu}\right), 48.2\left(\mathrm{CH}_{3} \mathrm{C}\right), 63.8\left(\mathrm{Me}_{3} \mathrm{C}\right.$ in $\left.{ }^{t} \mathrm{Bu}\right), 89.5$ (C-3 in indenyl), $96.4(\mathrm{C}-1$ in indenyl, the same side with the cyclobutylene bridge), 123,6 ( $p$-C in $\mathrm{Ph}-\mathrm{Zr}$ ), 124.9 (o-C in $\mathrm{PhC}-\mathrm{Zr}$ ), 125.2 ( $m-\mathrm{C}$ in $\mathrm{Ph}-\mathrm{Zr}), 126.5$ ( $p$-C in $\mathrm{PhC}-\mathrm{Zr}), 128.2$ ( $m$-C in $\mathrm{PhC}-\mathrm{Zr}), 143.0$ (C-2 in 
indenyl), 143.0 (o-C in Ph-Zr), 144.2 (ZrC-C in PhC-Zr), 179.5 (Zr-C in Ph-Zr), 236.1 $(\mathrm{N}=\mathrm{C}-\mathrm{Zr})$.

${ }^{1} \mathbf{H},{ }^{13} \mathbf{C}$-GHSQC $\left(599.7 \mathrm{MHz} / 150.8 \mathrm{MHz}, 298 \mathrm{~K}, \mathrm{C}_{6} \mathrm{D}_{5} \mathrm{CD}_{3}\right): \delta\left({ }^{1} \mathrm{H}\right) / \delta\left({ }^{13} \mathrm{C}\right)=0.68 /$ $31.8\left({ }^{t} \mathrm{Bu} / \mathrm{CH}_{3}\right.$ in $\left.{ }^{t} \mathrm{Bu}\right), 1.12 / 25.0\left(\mathrm{CH}_{3} / \mathrm{CH}_{3}\right), 1.68 / 31.1\left(\mathrm{CH}_{3} \mathrm{CCH}_{\text {back }} / \mathrm{CH}_{2}\right), 2.48 /$ $31.1\left(\mathrm{CH}_{3} \mathrm{CCH}_{\text {front }} / \mathrm{CH}_{2}\right), 6.10$ / 89.5 (H-3 in indenyl / C-3 in indenyl), 6.35 / 96.4 (H-1 in indenyl / C-1 in indenyl), 7.09 / 126.5 ( $p$-H in PhC-Zr / p-C in PhC-Zr), 7.19 / 123,6 ( $p$-H in $\mathrm{Ph}-\mathrm{Zr} /$ p-C in $\mathrm{Ph}-\mathrm{Zr}), 7.25$ / 125.2 ( $m-\mathrm{H}$ in $\mathrm{Ph}-\mathrm{Zr} / m-\mathrm{C}$ in $\mathrm{Ph}-\mathrm{Zr}$ ), 7.29 / 128.2 ( $m$-H in PhC-Zr / $m$-C in PhC-Zr), 7.44 / 124.9 (o-H in PhC-Zr / o-C in PhC-Zr), 7.82 / 143.3 (o-H in $\mathrm{Ph}-\mathrm{Zr} / o-\mathrm{C}$ in $\mathrm{Ph}-\mathrm{Zr}$ ).

${ }^{\mathbf{1}} \mathbf{H},{ }^{\mathbf{1 3}} \mathbf{C}$-GHMBC (599.7 MHz / $150.8 \mathrm{MHz}, 298 \mathrm{~K}, \mathrm{C}_{6} \mathrm{D}_{5} \mathrm{CD}_{3}$, selected ${ }^{13} \mathrm{C}$ traces): $\delta$ $\left({ }^{13} \mathrm{C}\right) / \delta\left({ }^{1} \mathrm{H}\right)=48.2 / 1.12,1.68,2.48\left(\mathrm{CH}_{3} \mathrm{C} / \mathrm{CH}_{3}, \mathrm{CH}_{3} \mathrm{CCH}_{\text {back }}, \mathrm{CH}_{3} \mathrm{CCH}_{\text {front }}\right) ; 63.8 /$ $0.68\left(\mathrm{Me}_{3} \mathrm{C}\right.$ in $\left.{ }^{t} \mathrm{Bu} /{ }^{t} \mathrm{Bu}\right) ; 143.0 / 1.12,1.68,2.48,6.10,6.35\left(\mathrm{C}-2\right.$ in indenyl $/ \mathrm{CH}_{3}$, $\mathrm{CH}_{3} \mathrm{CCH}_{\text {back }}, \mathrm{CH}_{3} \mathrm{CCH}_{\text {front }}, \mathrm{H}-3$ in indenyl, $\mathrm{H}-1$ in indenyl); 144.2 / 7.29 ( $\mathrm{ZrC}-\mathrm{C}$ in PhC-Zr / $m-\mathrm{H}$ in PhC-Zr); 179.5 / 7.82 (Zr-C in Ph-Zr / o-H in Ph-Zr), $236.1 / 7.44$ $(\mathrm{N}=\mathrm{C}-\mathrm{Zr} / o-\mathrm{H}$ in $\mathrm{PhC}-\mathrm{Zr})$.

${ }^{1} \mathbf{H}\left\{{ }^{1} \mathbf{H}\right\}$-TOCSY $\left(599.7 \mathrm{MHz}, 298 \mathrm{~K}, \mathrm{C}_{6} \mathrm{D}_{5} \mathrm{CD}_{3}\right.$, selected experiments): $\delta\left({ }^{1} \mathrm{H}\right)_{\text {irradiation }}$ $/ \delta\left({ }^{1} \mathrm{H}\right)_{\text {response }}=7.44$ / 7.29, $7.09(o-\mathrm{H}$ in PhC- $\mathrm{Zr} / m-\mathrm{H}$ in PhC-Zr, $p-\mathrm{H}$ in PhC-Zr) 7.82 / 7.25, 7.19 (o-H in $\mathrm{Ph}-\mathrm{Zr} / m-\mathrm{H}$ in $\mathrm{Ph}-\mathrm{Zr}, p-\mathrm{H}$ in $\mathrm{Ph}-\mathrm{Zr})$.

${ }^{1} \mathbf{H}\left\{{ }^{1} \mathbf{H}\right\}$-NOE $\left(599.7 \mathrm{MHz}, 298 \mathrm{~K}, \mathrm{C}_{6} \mathrm{D}_{5} \mathrm{CD}_{3}\right): \delta\left({ }^{1} \mathrm{H}\right)_{\text {irradiation }} / \delta\left({ }^{1} \mathrm{H}\right)_{\text {response }}=0.68 /$ 6.87, 7.44, $7.82\left({ }^{t} \mathrm{Bu} / \mathrm{H}-4\right.$ in indenyl, $o-\mathrm{H}$ in PhC-Zr, $o-\mathrm{H}$ in $\left.\mathrm{Ph}-\mathrm{Zr}\right) ; 1.12$ / 1.68, 6.10 $\left(\mathrm{CH}_{3} / \mathrm{CH}_{3} \mathrm{CCH}_{\text {back }}, \mathrm{H}-3\right.$ in indenyl); $1.68 / 1.12,2.48\left(\mathrm{CH}_{3} \mathrm{CCH}_{\text {back }} / \mathrm{CH}_{3}\right.$, $\left.\mathrm{CH}_{3} \mathrm{CCH}_{\text {front }}\right) ; 2.48$ / 1.68, $6.35\left(\mathrm{CH}_{3} \mathrm{CCH}_{\text {front }} / \mathrm{CH}_{3} \mathrm{CCH}_{\text {back }}, \mathrm{H}-1\right.$ in indenyl $) ; 6.10$ / 
1.12, 6.87, 7.44 (H-3 in indenyl / $\mathrm{CH}_{3}, \mathrm{H}-4$ in indenyl, $o-\mathrm{H}$ in PhC-Zr); 7.44 / 0.68, 6.10, 6.87, 7.29 $\left(o-\mathrm{H}\right.$ in $\mathrm{PhC}-\mathrm{Zr} /{ }^{t} \mathrm{Bu}, \mathrm{H}-3$ in indenyl, $\mathrm{H}-4$ in indenyl, $m-\mathrm{H}$ in $\left.\mathrm{PhC}-\mathrm{Zr}\right)$; 7.82 / 0.68, 6.35, 7.06, $7.25\left(o-\mathrm{H}\right.$ in $\mathrm{Ph}-\mathrm{Zr} /{ }^{t} \mathrm{Bu}, \mathrm{H}-1$ in indenyl, $\mathrm{H}-7$ in indenyl, $m-\mathrm{H}$ in $\mathrm{Ph}-\mathrm{Zr})$.

20-anti ( $\mathrm{Zr}-\mathrm{Ph}$ is at the opposite side to the cyclobutylene bridge and the $\mathrm{N}$ atom is inside):

${ }^{1} \mathbf{H}$ NMR $\left(599.8 \mathrm{MHz}, 298 \mathrm{~K}, \mathrm{C}_{6} \mathrm{D}_{5} \mathrm{CD}_{3}\right): \delta=0.78\left(\mathrm{~s}, 9 \mathrm{H},{ }^{t} \mathrm{BuN}=\mathrm{C}-\mathrm{Zr}\right), 1.16(\mathrm{~s}, 6 \mathrm{H}$, $\mathrm{CH}_{3}$ ), 1.61 (AA'BB', 2H, $\mathrm{CH}_{3} \mathrm{CCH}_{\text {back }}$ ), 2.30 (AA'BB', 2H, $\mathrm{CH}_{3} \mathrm{CCH}_{\text {front }}$ ), 6.14 (dd, J $=2.3 \mathrm{~Hz}, \mathrm{~J}=0.7 \mathrm{~Hz}, 2 \mathrm{H}, \mathrm{H}-3$ in indenyl), $6.23(\mathrm{dd}, \mathrm{J}=2.3 \mathrm{~Hz}, \mathrm{~J}=0.8 \mathrm{~Hz}, 2 \mathrm{H}, \mathrm{H}-1$ in indenyl, the same side with the cyclobutylene bridge), 6.87 (2H, H-7 in indenyl), 6.90 (2H, H-4 in indenyl), 7.08 (m, 1H, p-H in PhC-Zr), 7.12 (m, 1H, p-H in $\mathrm{Ph}-\mathrm{Zr}), 7.14$ (m, 2H, $m-\mathrm{H}$ in $\mathrm{Ph}-\mathrm{Zr}), 7.31$ (m, 2H, $m-\mathrm{H}$ in $\mathrm{PhC}-\mathrm{Zr}), 7.38$ (m, 2H, $o-\mathrm{H}$ in $\mathrm{PhC}-\mathrm{Zr}$ ), $7.58(\mathrm{~m}, 2 \mathrm{H}, o-\mathrm{H}$ in $\mathrm{Ph}-\mathrm{Zr})$.

${ }^{13} \mathrm{C}$ NMR $\left(150.8 \mathrm{MHz}, 298 \mathrm{~K}, \mathrm{C}_{6} \mathrm{D}_{5} \mathrm{CD}_{3}\right): \delta=25.6\left(\mathrm{CH}_{3}\right), 31.0\left(\mathrm{CH}_{2}\right), 32.0\left(\mathrm{CH}_{3}\right.$ in $\left.{ }^{t} \mathrm{Bu}\right), 48.5\left(\mathrm{CH}_{3} \mathrm{C}\right), 64.4\left(\mathrm{Me}_{3} \mathrm{C}\right.$ in $\left.{ }^{t} \mathrm{Bu}\right), 93.3$ (C-3 in indenyl), $91.5(\mathrm{C}-1$ in indenyl, the same side with the cyclobutylene bridge), 122.6 ( $o-\mathrm{C}$ in $\mathrm{PhC}-\mathrm{Zr}$ ), 123,4 ( $p$-C in $\mathrm{Ph}-\mathrm{Zr}$ ), 125.4 ( $m-\mathrm{C}$ in $\mathrm{Ph}-\mathrm{Zr}), 126.6$ ( $p$-C in $\mathrm{PhC}-\mathrm{Zr}), 128.6$ ( $m-\mathrm{C}$ in $\mathrm{PhC}-\mathrm{Zr}), 142.7$ (C-2 in indenyl), 142.9 (o-C in Ph-Zr), 146.9 (ZrC-C in PhC-Zr), 181.2 (Zr-C in Ph-Zr), 236.8 $(\mathrm{N}=\mathrm{C}-\mathrm{Zr})$.

${ }^{\mathbf{1}} \mathbf{H},{ }^{\mathbf{1 3}} \mathbf{C}$-GHSQC $\left(599.7 \mathrm{MHz} / 150.8 \mathrm{MHz}, 298 \mathrm{~K}, \mathrm{C}_{6} \mathrm{D}_{5} \mathrm{CD}_{3}\right): \delta\left({ }^{1} \mathrm{H}\right) / \delta\left({ }^{13} \mathrm{C}\right)=0.78 /$ $32.0\left({ }^{t} \mathrm{Bu} / \mathrm{CH}_{3}\right.$ in $\left.{ }^{t} \mathrm{Bu}\right), 1.16 / 25.6\left(\mathrm{CH}_{3} / \mathrm{CH}_{3}\right), 1.61 / 31.0\left(\mathrm{CH}_{3} \mathrm{CCH}_{\text {back }} / \mathrm{CH}_{2}\right), 2.30$ / $31.0\left(\mathrm{CH}_{3} \mathrm{CCH}_{\text {front }} / \mathrm{CH}_{2}\right), 6.14$ / 93.3 (3-H in indenyl / C-3 in indenyl), 6.23 / 91.5 
(H-1 in indenyl / C-1 in indenyl), 7.08 / 126.6 ( $p-\mathrm{H}$ in $\mathrm{PhC}-\mathrm{Zr} / p-\mathrm{C}$ in $\mathrm{PhC}-\mathrm{Zr}$ ), 7.12 / 123,4 ( $p$-H in $\mathrm{Ph}-\mathrm{Zr} / p$-C in $\mathrm{Ph}-\mathrm{Zr}), 7.14$ / 125.4 ( $m-\mathrm{H}$ in $\mathrm{Ph}-\mathrm{Zr} / m-\mathrm{C}$ in $\mathrm{Ph}-\mathrm{Zr}), 7.31$ / 128.6 ( $m-\mathrm{H}$ in $\mathrm{PhC}-\mathrm{Zr} / m-\mathrm{C}$ in $\mathrm{PhC}-\mathrm{Zr}$ ), 7.38 / 122.6 ( $o-\mathrm{H}$ in $\mathrm{PhC}-\mathrm{Zr} / o-\mathrm{C}$ in $\mathrm{PhC}-\mathrm{Zr}$ ), $7.58 / 142.9$ (o-H in $\mathrm{Ph}-\mathrm{Zr} / o-\mathrm{C}$ in $\mathrm{Ph}-\mathrm{Zr})$.

${ }^{\mathbf{1}} \mathbf{H},{ }^{\mathbf{1 3}} \mathbf{C}-\mathbf{G H M B C}\left(599.7 \mathrm{MHz} / 150.8 \mathrm{MHz}, 298 \mathrm{~K}, \mathrm{C}_{6} \mathrm{D}_{5} \mathrm{CD}_{3}\right.$, selected ${ }^{13} \mathrm{C}$ traces): $\delta$ $\left({ }^{13} \mathrm{C}\right) / \delta\left({ }^{1} \mathrm{H}\right)=48.5 / 1.16,1.61,2.30\left(\mathrm{CH}_{3} \mathrm{C} / \mathrm{CH}_{3}, \mathrm{CH}_{3} \mathrm{CCH}_{\text {back }}, \mathrm{CH}_{3} \mathrm{CCH}_{\text {front }}\right) ; 64.4$ / $0.78\left(\mathrm{Me}_{3} \mathrm{C}\right.$ in $\left.{ }^{t} \mathrm{Bu} /{ }^{t} \mathrm{Bu}\right) ; 142.7 / 1.16,1.61,2.30,6.14,6.23\left(\mathrm{C}-2\right.$ in indenyl $/ \mathrm{CH}_{3}$, $\mathrm{CH}_{3} \mathrm{CCH}_{\text {back }}, \mathrm{CH}_{3} \mathrm{CCH}_{\text {front }}$, H-3 in indenyl, $\mathrm{H}-1$ in indenyl); 146.9 / 7.31 (ZrC-C in $\mathrm{PhC}-\mathrm{Zr} / m-\mathrm{H}$ in $\mathrm{PhC}-\mathrm{Zr}) ; 181.2$ / 7.58 (Zr-C in $\mathrm{Ph}-\mathrm{Zr} / o-\mathrm{H}$ in $\mathrm{Ph}-\mathrm{Zr}$ ), $236.8 / 7.38$ $(\mathrm{N}=\mathrm{C}-\mathrm{Zr} / o-\mathrm{H}$ in $\mathrm{PhC}-\mathrm{Zr})$.

${ }^{1} \mathbf{H}\left\{{ }^{1} \mathbf{H}\right\}$-TOCSY $\left(599.7 \mathrm{MHz}, 298 \mathrm{~K}, \mathrm{C}_{6} \mathrm{D}_{5} \mathrm{CD}_{3}\right.$, selected experiments): $\delta\left({ }^{1} \mathrm{H}\right)_{\text {irradiation }}$ $/ \delta\left({ }^{1} \mathrm{H}\right)_{\text {response }}=7.38 / 7.31,7.08(o-\mathrm{H}$ in $\mathrm{PhC}-\mathrm{Zr} / m-\mathrm{H}$ in $\mathrm{PhC}-\mathrm{Zr}, p-\mathrm{H}$ in $\mathrm{PhC}-\mathrm{Zr}) ; 7.58$ / 7.14, $7.12(o-\mathrm{H}$ in $\mathrm{Ph}-\mathrm{Zr} / m-\mathrm{H}$ in $\mathrm{Ph}-\mathrm{Zr}, p-\mathrm{H}$ in $\mathrm{Ph}-\mathrm{Zr})$.

${ }^{1} \mathbf{H}\left\{{ }^{1} \mathbf{H}\right\}$-NOE $\left(599.7 \mathrm{MHz}, 298 \mathrm{~K}, \mathrm{C}_{6} \mathrm{D}_{5} \mathrm{CD}_{3}\right): \delta\left({ }^{1} \mathrm{H}\right)_{\text {irradiation }} / \delta\left({ }^{1} \mathrm{H}\right)_{\text {response }}=0.78 /$ 6.87, 7.38, $7.58\left({ }^{t} \mathrm{Bu} / \mathrm{H}-7\right.$ in indenyl, $o-\mathrm{H}$ in PhC-Zr, $o-\mathrm{H}$ in $\left.\mathrm{Ph}-\mathrm{Zr}\right) ; 1.16$ / 1.61, 6.14 $\left(\mathrm{CH}_{3} / \mathrm{CH}_{3} \mathrm{CCH}_{\text {back }}, 3-\mathrm{H}\right.$ in indenyl); $1.61 / 1.16,2.30\left(\mathrm{CH}_{3} \mathrm{CCH}_{\text {back }} / \mathrm{CH}_{3}\right.$, $\left.\mathrm{CH}_{3} \mathrm{CCH}_{\text {front }}\right) ; 2.30$ / 1.61, $6.23\left(\mathrm{CH}_{3} \mathrm{CCH}_{\text {front }} / \mathrm{CH}_{3} \mathrm{CCH}_{\text {back }}, \mathrm{H}-1\right.$ in indenyl $) ; 6.14$ / 1.16, 6.90, 7.58 (3-H in indenyl / $\mathrm{CH}_{3}, \mathrm{H}-4$ in indenyl, $o-\mathrm{H}$ in $\left.\mathrm{Ph}-\mathrm{Zr}\right) ; 7.38$ / 0.78, 6.23, 6.87, $7.31\left(o-\mathrm{H}\right.$ in $\mathrm{PhC}-\mathrm{Zr} /{ }^{t} \mathrm{Bu}, \mathrm{H}-1$ in indenyl, $\mathrm{H}-7$ in indenyl, $m-\mathrm{H}$ in $\left.\mathrm{PhC}-\mathrm{Zr}\right) ; 7.58$ / $0.78,6.14,6.90,7.14\left(o-\mathrm{H}\right.$ in $\mathrm{Ph}-\mathrm{Zr} /{ }^{t} \mathrm{Bu}, 3-\mathrm{H}$ in indenyl, $\mathrm{H}-4$ in indenyl, $m-\mathrm{H}$ in $\mathrm{Ph}-\mathrm{Zr})$.

All the other ${ }^{1} \mathrm{H}$ NMR signals are within $\delta 7.32-6.20$ as multiplets. 
Some important ${ }^{13} \mathrm{C}$ NMR signals which can not be assigned (in 19-syn or -anti): $\delta$ $143.5\left(\mathrm{C}_{5} \mathrm{H}_{5} \mathrm{C}-\mathrm{CZr}\right), 144.1\left(\mathrm{C}_{5} \mathrm{H}_{5} \mathrm{C}-\mathrm{CZr}\right), 181.0(\mathrm{Zr}-\mathrm{C}$ in $\mathrm{Ph}-\mathrm{Zr}), 181.3$ (Zr-C in $\left.\mathrm{Ph}-\mathrm{Zr}\right)$, $233.2(\mathrm{~N}=\mathrm{C}-\mathrm{Zr}), 233.5(\mathrm{~N}=\mathrm{C}-\mathrm{Zr})$.

$\eta^{2}$-N-tert-butyliminobenzoyl phenyl ansa-biscyclopentadienyl zirconium complexes 22

22-syn ( $\mathrm{Zr}-\mathrm{Ph}$ is at the same side with the cyclobutylene bridge, minor product):

${ }^{1} \mathbf{H}$ NMR (599.7 MHz, 298K, $\left.\mathrm{C}_{6} \mathrm{D}_{5} \mathrm{CD}_{3}\right): \delta=0.84\left(\mathrm{~s}, 9 \mathrm{H},{ }^{t} \mathrm{BuN}=\mathrm{C}-\mathrm{Zr}\right), 1.04(\mathrm{~s}, 6 \mathrm{H}$, $\mathrm{CH}_{3}$ ), 1.56 (AA'BB', 2H, $\mathrm{CH}_{3} \mathrm{CCH}_{\text {back }}$ ), 2.21 (AA'BB', 2H, $\mathrm{CH}_{3} \mathrm{CCH}_{\text {front }}$ ), 5.36 (m, 2H, H-3 in Cp), 5.53 (m, 2H, H-2 in Cp), 5.76 (m, 2H, H-4 in Cp), 6.09 (m, 2H, H-5 in $\mathrm{Cp}$, the same side with the cyclobutylene bridge), 6,78 (m, 2H, o-H in $\mathrm{PhC}-\mathrm{Zr}), 6.94$ (m, 2H, p-H in $\mathrm{PhC}-\mathrm{Zr}), 7.13(\mathrm{~m}, 1 \mathrm{H}, m-\mathrm{H}$ in $\mathrm{PhC}-\mathrm{Zr}), 7.17$ (m, 2H, $p-\mathrm{H}$ in $\mathrm{Ph}-\mathrm{Zr}$ ), $7.29(\mathrm{~m}, 1 \mathrm{H}, m-\mathrm{H}$ in $\mathrm{Ph}-\mathrm{Zr}), 7.96(\mathrm{~m}, 2 \mathrm{H}, o-\mathrm{H}$ in $\mathrm{Ph}-\mathrm{Zr})$.

${ }^{13}$ C NMR (150.8 MHz, 298K, $\left.\mathrm{C}_{6} \mathrm{D}_{5} \mathrm{CD}_{3}\right): \delta=25.3\left(\mathrm{CH}_{3}\right), 30.7\left(\mathrm{CH}_{2}\right), 30.9\left(\mathrm{CH}_{3}\right.$ in $\left.{ }^{t} \mathrm{Bu}\right), 48.1\left(\mathrm{CH}_{3} \mathrm{C}\right), 62.3\left(\mathrm{Me}_{3} \mathrm{C}\right.$ in $\left.{ }^{t} \mathrm{Bu}\right), 99.6(\mathrm{C}-2$ in $\mathrm{Cp}), 105.6(\mathrm{C}-5$ in $\mathrm{Cp}$, the same side with the cyclobutylene bridge), 110.1 (C-4 in Cp), 112.0 (C-3 in Cp), 121.4 (o-C in $\mathrm{PhC}-\mathrm{Zr}$ ), 123.7 ( $p$-C in $\mathrm{Ph}-\mathrm{Zr}), 125.9$ ( $p-\mathrm{C}$ in $\mathrm{PhC}-\mathrm{Zr}), 126.2$ ( $m-\mathrm{C}$ in $\mathrm{Ph}-\mathrm{Zr}$ ), 128.6 ( $m-\mathrm{C}$ in $\mathrm{PhC}-\mathrm{Zr}$ ), 135.6 (1-C in $\mathrm{Cp}$ ), 142.7 (o-C in $\mathrm{Ph}-\mathrm{Zr}$ ), 147.0 (ZrC-C in $\mathrm{PhC}-\mathrm{Zr}$ ), 176.5 (Zr-C in $\mathrm{Ph}-\mathrm{Zr}), 236.0(\mathrm{~N}=\mathrm{C}-\mathrm{Zr})$.

${ }^{1} \mathbf{H},{ }^{13} \mathbf{C}$-GHSQC $\left(599.7 \mathrm{MHz} / 150.8 \mathrm{MHz}, 298 \mathrm{~K}, \mathrm{C}_{6} \mathrm{D}_{5} \mathrm{CD}_{3}\right): \delta\left({ }^{1} \mathrm{H}\right) / \delta\left({ }^{13} \mathrm{C}\right)=0.84 /$ $30.9\left({ }^{t} \mathrm{Bu} / \mathrm{CH}_{3}\right.$ in $\left.{ }^{t} \mathrm{Bu}\right), 1.04 / 25.3\left(\mathrm{CH}_{3} / \mathrm{CH}_{3}\right), 1.56 / 30.7\left(\mathrm{CH}_{3} \mathrm{CCH}_{\text {back }} / \mathrm{CH}_{2}\right), 2.21 /$ $30.7\left(\mathrm{CH}_{3} \mathrm{CCH}_{\text {front }} / \mathrm{CH}_{2}\right), 5.36 / 112.0(\mathrm{H}-3$ in $\mathrm{Cp} / \mathrm{C}-3$ in $\mathrm{Cp}), 5.53$ / $99.6(\mathrm{H}-2$ in $\mathrm{Cp} /$ C-2 in Cp), 5.76 / 110.1 (H-4 in Cp / C-4 in Cp), 6.09 / 105.6 (H-5 in Cp / C-5 in Cp), 
6,78 / 121.4 (o-H in $\mathrm{PhC}-\mathrm{Zr} / o-\mathrm{C}$ in $\mathrm{PhC}-\mathrm{Zr}), 6.94 / 125.9(p-\mathrm{H}$ in $\mathrm{PhC}-\mathrm{Zr} / p-\mathrm{C}$ in PhC-Zr), 7.13 / 128.6 ( $m-\mathrm{H}$ in $\mathrm{PhC}-\mathrm{Zr} / m-\mathrm{C}$ in $\mathrm{PhC}-\mathrm{Zr}$ ), 7.17 / 123.7 ( $p-\mathrm{H}$ in $\mathrm{Ph}-\mathrm{Zr} /$ p-C in $\mathrm{Ph}-\mathrm{Zr}), 7.29$ / 126.2 ( $m-\mathrm{H}$ in $\mathrm{Ph}-\mathrm{Zr} / m-\mathrm{C}$ in $\mathrm{Ph}-\mathrm{Zr}$ ), 7.96 / 142.7 (o-H in $\mathrm{Ph}-\mathrm{Zr}$ / $o-\mathrm{C}$ in $\mathrm{Ph}-\mathrm{Zr}$ ).

${ }^{\mathbf{1}} \mathbf{H},{ }^{\mathbf{1 3}} \mathbf{C}$-GHMBC (599.7 MHz / $150.8 \mathrm{MHz}, 298 \mathrm{~K}, \mathrm{C}_{6} \mathrm{D}_{5} \mathrm{CD}_{3}$, selected ${ }^{13} \mathrm{C}$ traces): $\delta$ $\left({ }^{13} \mathrm{C}\right) / \delta\left({ }^{1} \mathrm{H}\right)=48.1 / 1.04,1.56,2.21\left(\mathrm{CH}_{3} \mathrm{C} / \mathrm{CH}_{3}, \mathrm{CH}_{3} \mathrm{CCH}_{\text {back }}, \mathrm{CH}_{3} \mathrm{CCH}_{\text {front }}\right) ; 62.3 /$ $0.84\left(\mathrm{Me}_{3} \mathrm{C}\right.$ in $\left.{ }^{t} \mathrm{Bu} /{ }^{t} \mathrm{Bu}\right) ; 135.6 / 1.04,1.56,2.21,5.53,5.76,6.09\left(\mathrm{C}-1\right.$ in $\mathrm{Cp} / \mathrm{CH}_{3}$, $\mathrm{CH}_{3} \mathrm{CCH}_{\text {back }}, \mathrm{CH}_{3} \mathrm{CCH}_{\text {front }}, \mathrm{H}-2$ in $\mathrm{Cp}, \mathrm{H}-4$ in $\mathrm{Cp}, \mathrm{H}-5$ in $\mathrm{Cp}$ ), 147.0 / 6.78 (ZrC-C in $\mathrm{PhC}-\mathrm{Zr} / o-\mathrm{H}$ in $\mathrm{PhC}-\mathrm{Zr}) ; 176.5$ / 7.29, 7.96 (Zr-C in $\mathrm{Ph}-\mathrm{Zr} / m-\mathrm{H}$ in $\mathrm{Ph}-\mathrm{Zr}, o-\mathrm{H}$ in $\mathrm{Ph}-\mathrm{Zr}) ; 236.0 / 6.78$ (N=C-Zr / o-H in $\mathrm{PhC}-\mathrm{Zr})$.

${ }^{1} \mathbf{H}\left\{{ }^{1} \mathbf{H}\right\}$-TOCSY $\left(599.7 \mathrm{MHz}, 298 \mathrm{~K}, \mathrm{C}_{6} \mathrm{D}_{5} \mathrm{CD}_{3}\right.$, selected experiments): $\delta\left({ }^{1} \mathrm{H}\right)_{\text {irradiation }}$ $/ \delta\left({ }^{1} \mathrm{H}\right)_{\text {response }}=6.78 / 6.94,7.13(o-\mathrm{H}$ in $\mathrm{PhC}-\mathrm{Zr} / p-\mathrm{H}$ in $\mathrm{PhC}-\mathrm{Zr}, m-\mathrm{H}$ in $\mathrm{PhC}-\mathrm{Zr}) ; 7.96$ / 7.17, $7.29(o-\mathrm{H}$ in $\mathrm{Ph}-\mathrm{Zr} / p-\mathrm{H}$ in $\mathrm{Ph}-\mathrm{Zr}, m-\mathrm{H}$ in $\mathrm{Ph}-\mathrm{Zr})$.

${ }^{1} \mathbf{H}\left\{{ }^{1} \mathbf{H}\right\}$-NOE $\left(599.7 \mathrm{MHz}, 298 \mathrm{~K}, \mathrm{C}_{6} \mathrm{D}_{5} \mathrm{CD}_{3}\right): \delta\left({ }^{1} \mathrm{H}\right)_{\text {irradiation }} / \delta\left({ }^{1} \mathrm{H}\right)_{\text {response }}=0.84 /$ 5.36, 5.76, 6.78, $7.96\left({ }^{t} \mathrm{Bu} / \mathrm{H}-3\right.$ in Cp, $\mathrm{H}-4$ in $\mathrm{Cp}, o-\mathrm{H}$ in $\mathrm{PhC}-\mathrm{Zr}, o-\mathrm{H}$ in $\left.\mathrm{Ph}-\mathrm{Zr}\right) ; 2.21 /$ 1.56, $6.09\left(\mathrm{CH}_{3} \mathrm{CCH}_{\text {front }} / \mathrm{CH}_{3} \mathrm{CCH}_{\text {back }}, \mathrm{H}-5\right.$ in $\left.\mathrm{Cp}\right) ; 5.36$ / 0.84, 5.53, 5.76, 6.78 (H-3 in $\mathrm{Cp} /{ }^{t} \mathrm{Bu}, \mathrm{H}-2$ in $\mathrm{Cp}, \mathrm{H}-4$ in $\mathrm{Cp}, o-\mathrm{H}$ in $\left.\mathrm{PhC}-\mathrm{Zr}\right) ; 5.53 / 1.04,5.36,6.78(\mathrm{H}-2$ in $\mathrm{Cp} /$ $\mathrm{CH}_{3}, \mathrm{H}-3$ in $\mathrm{Cp}, o-\mathrm{H}$ in $\left.\mathrm{PhC}-\mathrm{Zr}\right)$; 5.76 / 5.36, 6.09, 7.96 (H-4 in $\mathrm{Cp} / \mathrm{H}-3$ in $\mathrm{Cp}, \mathrm{H}-5$ in $\mathrm{Cp}, o-\mathrm{H}$ in $\mathrm{Ph}-\mathrm{Zr})$; 6.09 / 2.21, 5.76, $7.96\left(\mathrm{H}-5\right.$ in $\mathrm{Cp} / \mathrm{CH}_{3} \mathrm{CCH}_{\text {front }}, \mathrm{H}-4$ in $\mathrm{Cp}, o-\mathrm{H}$ in $\mathrm{Ph}-\mathrm{Zr}) ; 6.78$ / 0.84, 5.36, 5.53, 7.13 (o-H in $\mathrm{PhC}-\mathrm{Zr} /{ }^{t} \mathrm{Bu}, \mathrm{H}-3$ in $\mathrm{Cp}, \mathrm{H}-2$ in $\mathrm{Cp}, m-\mathrm{H}$ in PhC-Zr); 7.96 / 0.84, 5.76, 6.09, $7.29\left(o-\mathrm{H}\right.$ in $\mathrm{Ph}-\mathrm{Zr} /{ }^{t} \mathrm{Bu}, \mathrm{H}-4$ in $\mathrm{Cp}, \mathrm{H}-5$ in $\mathrm{Cp}, m-\mathrm{H}$ in $\mathrm{Ph}-\mathrm{Zr})$. 
22-anti $(\mathrm{Zr}-\mathrm{Ph}$ is at the opposite side to the cyclobutylene bridge, major product):

${ }^{1} \mathrm{H}$ NMR $\left(599.7 \mathrm{MHz}, 298 \mathrm{~K}, \mathrm{C}_{6} \mathrm{D}_{5} \mathrm{CD}_{3}\right): \delta=0.95\left(\mathrm{~s}, 9 \mathrm{H},{ }^{t} \mathrm{BuN}=\mathrm{C}-\mathrm{Zr}\right), 1.06(\mathrm{~s}, 6 \mathrm{H}$, $\mathrm{CH}_{3}$ ), 1.56 (AA'BB', 2H, $\mathrm{CH}_{3} \mathrm{CCH}_{\text {back }}$ ), 2.16 (AA'BB', 2H, $\mathrm{CH}_{3} \mathrm{CCH}_{\text {front }}$ ), 4.97 (m, 2H, H-4 in Cp), 5.61 (m, 2H, H-2 in Cp), 5.86 (m, 2H, H-5 in Cp, the same side with the cyclobutylene bridge), 6.14 (m, 2H, H-3 in Cp), 6.80 (m, 2H, o-H in PhC-Zr), 6.94 (m, 2H, $p-\mathrm{H}$ in $\mathrm{PhC}-\mathrm{Zr}), 7.14(\mathrm{~m}, 1 \mathrm{H}, m-\mathrm{H}$ in $\mathrm{PhC}-\mathrm{Zr}), 7.16(\mathrm{~m}, 2 \mathrm{H}, p-\mathrm{H}$ in $\mathrm{Ph}-\mathrm{Zr})$, $7.27(\mathrm{~m}, 1 \mathrm{H}, m-\mathrm{H}$ in $\mathrm{Ph}-\mathrm{Zr}), 7.85$ (m, 2H, $o-\mathrm{H}$ in $\mathrm{Ph}-\mathrm{Zr})$.

${ }^{13}$ C NMR $\left(150.8 \mathrm{MHz}, 298 \mathrm{~K}, \mathrm{C}_{6} \mathrm{D}_{5} \mathrm{CD}_{3}\right): \delta=25.7\left(\mathrm{CH}_{3}\right), 30.7\left(\mathrm{CH}_{2}\right), 30.9\left(\mathrm{CH}_{3}\right.$ in $\left.{ }^{t} \mathrm{Bu}\right), 48.4\left(\mathrm{CH}_{3} \mathrm{C}\right), 62.1\left(\mathrm{Me}_{3} \mathrm{C}\right.$ in $\left.{ }^{t} \mathrm{Bu}\right), 100.7(\mathrm{C}-2$ in $\mathrm{Cp}), 100.8(\mathrm{C}-5$ in $\mathrm{Cp}$, the same side with the cyclobutylene bridge), 107.7 (C-4 in Cp), 118.3 (C-3 in Cp), 121.0 (o-C in $\mathrm{PhC}-\mathrm{Zr}$ ), 123.6 ( $p-\mathrm{C}$ in $\mathrm{Ph}-\mathrm{Zr}), 125.8$ ( $p-\mathrm{C}$ in $\mathrm{PhC}-\mathrm{Zr}), 126.0$ ( $m-\mathrm{C}$ in $\mathrm{Ph}-\mathrm{Zr}), 128.7$ ( $m$-C in $\mathrm{PhC}-\mathrm{Zr}), 136.0$ (C-1 in $\mathrm{Cp}), 142.6$ ( $o-\mathrm{C}$ in $\mathrm{Ph}-\mathrm{Zr}), 147.4$ (ZrC-C in PhC-Zr), 176.3 ( $\mathrm{Zr}-\mathrm{C}$ in $\mathrm{Ph}-\mathrm{Zr}), 236.5$ (N=C-Zr).

${ }^{1} \mathbf{H},{ }^{13} \mathbf{C}-G H S Q C\left(599.7 \mathrm{MHz} / 150.8 \mathrm{MHz}, 298 \mathrm{~K}, \mathrm{C}_{6} \mathrm{D}_{5} \mathrm{CD}_{3}\right): \delta\left({ }^{1} \mathrm{H}\right) / \delta\left({ }^{13} \mathrm{C}\right)=0.95 /$ $30.9\left({ }^{t} \mathrm{Bu} / \mathrm{CH}_{3}\right.$ in $\left.{ }^{t} \mathrm{Bu}\right), 1.06 / 25.7\left(\mathrm{CH}_{3} / \mathrm{CH}_{3}\right), 1.56 / 30.7\left(\mathrm{CH}_{3} \mathrm{CCH}_{\text {back }} / \mathrm{CH}_{2}\right), 2.16 /$ $30.7\left(\mathrm{CH}_{3} \mathrm{CCH}_{\text {front }} / \mathrm{CH}_{2}\right), 4.97$ / 107.7 (H-4 in Cp / C-4 in Cp), 5.61 / $100.7(\mathrm{H}-2$ in $\mathrm{Cp}$ / C-2 in Cp), 5.86 / 100.8 (H-5 in Cp / C-5 in Cp), 6.14 / 118.3 (H-3 in Cp / C-3 in Cp), 6.80 / 121.0 (o-H in $\mathrm{PhC}-\mathrm{Zr} / o-\mathrm{C}$ in $\mathrm{PhC}-\mathrm{Zr}), 6.94$ / 125.8 ( $p-\mathrm{H}$ in $\mathrm{PhC}-\mathrm{Zr} / p-\mathrm{C}$ in $\mathrm{PhC}-\mathrm{Zr}), 7.14$ / 128.7 ( $m-\mathrm{H}$ in $\mathrm{PhC}-\mathrm{Zr} / m-\mathrm{C}$ in $\mathrm{PhC}-\mathrm{Zr}), 7.16 / 123.6(p-\mathrm{H}$ in $\mathrm{Ph}-\mathrm{Zr} /$ p-C in $\mathrm{Ph}-\mathrm{Zr}$ ), 7.27 / 126.0 ( $m-\mathrm{H}$ in $\mathrm{Ph}-\mathrm{Zr} / m-\mathrm{C}$ in $\mathrm{Ph}-\mathrm{Zr}$ ), 7.85 / 142.6 (o-H in $\mathrm{Ph}-\mathrm{Zr} /$ $o-\mathrm{C}$ in $\mathrm{Ph}-\mathrm{Zr})$.

${ }^{\mathbf{1}} \mathbf{H},{ }^{\mathbf{1 3}} \mathbf{C}$-GHMBC $\left(599.7 \mathrm{MHz} / 150.8 \mathrm{MHz}, 298 \mathrm{~K}, \mathrm{C}_{6} \mathrm{D}_{5} \mathrm{CD}_{3}\right.$, selected ${ }^{13} \mathrm{C}$ traces $): \delta$ 
$\left({ }^{13} \mathrm{C}\right) / \delta\left({ }^{1} \mathrm{H}\right)=48.4 / 1.06,1.56,2.16\left(\mathrm{CH}_{3} \mathrm{C} / \mathrm{CH}_{3}, \mathrm{CH}_{3} \mathrm{CCH}_{\text {back }}, \mathrm{CH}_{3} \mathrm{CCH}_{\text {front }}\right), 62.1 /$ $0.95\left(\mathrm{Me}_{3} \mathrm{C}\right.$ in $\left.{ }^{t} \mathrm{Bu} /{ }^{t} \mathrm{Bu}\right), 136.0 / 1.06,1.56,2.16,4.97,5.61,5.86,6.14(\mathrm{C}-1$ in $\mathrm{Cp} /$ $\mathrm{CH}_{3}, \mathrm{CH}_{3} \mathrm{CCH}_{\text {back }}, \mathrm{CH}_{3} \mathrm{CCH}_{\text {front }}, \mathrm{H}-4$ in $\mathrm{Cp}, \mathrm{H}-2$ in $\mathrm{Cp}, \mathrm{H}-5$ in $\mathrm{Cp}, \mathrm{H}-3$ in $\mathrm{Cp}$ ); 147.4 / 7.14 (ZrC-C in PhC-Zr / $m-\mathrm{H}$ in $\mathrm{PhC}-\mathrm{Zr}$ ), 176.3 / 7.27, 7.85 ( $\mathrm{Zr}-\mathrm{C}$ in $\mathrm{Ph}-\mathrm{Zr} / m-\mathrm{H}$ in $\mathrm{Ph}-\mathrm{Zr}, o-\mathrm{H}$ in $\mathrm{Ph}-\mathrm{Zr}), 236.5$ / 6.80 (N=C-Zr / $o-\mathrm{H}$ in $\mathrm{PhC}-\mathrm{Zr})$.

${ }^{1} \mathbf{H}\left\{{ }^{1} \mathbf{H}\right\}$-TOCSY $\left(599.7 \mathrm{MHz}, 298 \mathrm{~K}, \mathrm{C}_{6} \mathrm{D}_{5} \mathrm{CD}_{3}\right.$, selected experiments): $\delta\left({ }^{1} \mathrm{H}\right)_{\text {irradiation }}$ $/ \delta\left({ }^{1} \mathrm{H}\right)_{\text {response }}=6.80$ / 6.94, $7.14(o-\mathrm{H}$ in $\mathrm{PhC}-\mathrm{Zr} / p-\mathrm{H}$ in $\mathrm{PhC}-\mathrm{Zr}, m-\mathrm{H}$ in $\mathrm{PhC}-\mathrm{Zr}) ; 7.85$ / 7.16, 7.27 (o-H in $\mathrm{Ph}-\mathrm{Zr} / p-\mathrm{H}$ in $\mathrm{Ph}-\mathrm{Zr}, m-\mathrm{H}$ in $\mathrm{Ph}-\mathrm{Zr}$ ).

${ }^{1} \mathbf{H}\left\{{ }^{1} \mathbf{H}\right\}$-NOE $\left(599.7 \mathrm{MHz}, 298 \mathrm{~K}, \mathrm{C}_{6} \mathrm{D}_{5} \mathrm{CD}_{3}\right): \delta\left({ }^{1} \mathrm{H}\right)_{\text {irradiation }} / \delta\left({ }^{1} \mathrm{H}\right)_{\text {response }}=0.95 /$ 4.97, 6.14, 6.80, 7.85 ( ${ }^{t} \mathrm{Bu} / \mathrm{H}-4$ in Cp, H-3 in Cp, $o-\mathrm{H}$ in PhC-Zr, $o-\mathrm{H}$ in $\left.\mathrm{Ph}-\mathrm{Zr}\right) ; 1.06$ / 1.56, $5.61\left(\mathrm{CH}_{3} / \mathrm{CH}_{3} \mathrm{CCH}_{\text {back }}, \mathrm{H}-2\right.$ in $\left.\mathrm{Cp}\right) ; 2.16 / 1.56,5.86\left(\mathrm{CH}_{3} \mathrm{CCH}_{\text {front }} /\right.$ $\mathrm{CH}_{3} \mathrm{CCH}_{\text {back }}, \mathrm{H}-5$ in $\left.\mathrm{Cp}\right)$; 4.97 / 0.95, 5.86, 6.14, $6.80\left({ }^{t} \mathrm{Bu}, \mathrm{H}-4\right.$ in Cp / H-5 in Cp, H-3 in $\mathrm{Cp}, o-\mathrm{H}$ in $\mathrm{PhC}-\mathrm{Zr}) ; 5.61 / 1.06,6.14,7.85\left(\mathrm{H}-2\right.$ in $\mathrm{Cp} / \mathrm{CH}_{3}, \mathrm{H}-3$ in $\mathrm{Cp}, o-\mathrm{H}$ in Ph-Zr); 5.86 / 2.16, 4.97, 6.80 (H-5 in $\mathrm{Cp} / \mathrm{CH}_{3} \mathrm{CCH}_{\text {front }}, \mathrm{H}-4$ in $\mathrm{Cp}, o-\mathrm{H}$ in $\mathrm{PhC}-\mathrm{Zr}$ ); 6.14 / 4.97, 5.61, 7.85 (H-3 in Cp / H-4 in Cp, H-2 in Cp, o-H in Ph-Zr); 6.80 / 0.95, 4.97, 5.86, 7.14 (o-H in $\mathrm{PhC}-\mathrm{Zr} /{ }^{t} \mathrm{Bu}, \mathrm{H}-4$ in $\mathrm{Cp}, \mathrm{H}-5$ in $\mathrm{Cp}, m-\mathrm{H}$ in $\left.\mathrm{PhC}-\mathrm{Zr}\right) ; 7.85$ / 0.95, 5.61, 6.14, 7.27 (o-H in $\mathrm{Ph}-\mathrm{Zr} /{ }^{t} \mathrm{Bu}, \mathrm{H}-2$ in $\mathrm{Cp}, \mathrm{H}-3$ in $\mathrm{Cp}, m-\mathrm{H}$ in $\mathrm{Ph}-\mathrm{Zr}$ ).

$\eta^{2}$-N-tert-butyliminoacetyl methyl ansa-biscyclopentadienyl zirconium complexes 24

24-syn $\left(\mathrm{Zr}-\mathrm{CH}_{3}\right.$ is at the same side with the cyclobutylene bridge, minor product):

${ }^{1} \mathrm{H}$ NMR $\left(599.7 \mathrm{MHz}, 298 \mathrm{~K}, \mathrm{C}_{6} \mathrm{D}_{5} \mathrm{CD}_{3}\right): \delta=0.22\left(\mathrm{~s}, 3 \mathrm{H} \mathrm{Zr}-\mathrm{CH}_{3}\right), 1.06(\mathrm{~s}, 9 \mathrm{H}$ $\left.{ }^{t} \mathrm{BuN}=\mathrm{C}-\mathrm{Zr}\right), 1.19\left(\mathrm{~s}, 6 \mathrm{H} \mathrm{CH}_{3}\right), 1.67\left(\mathrm{AA}^{\prime} \mathrm{BB}\right.$ ', 2H $\left.\mathrm{CH}_{3} \mathrm{CCH}_{\text {back }}\right), 2.31$ (s, 3H, 
$\mathrm{CH}_{3} \mathrm{C}-\mathrm{Zr}$ ), 2.33 (AA'BB', 2H, $\mathrm{CH}_{3} \mathrm{CCH}_{\text {front }}$ ), 4.93 (m, 2H, H-3 in Cp), 5.33 (m, 2H, H-4 in Cp), 5.49 (m, 2H, H-2 in Cp), 5.88 (m, 2H, H-5 in Cp, the same side with the cyclobutylene bridge).

${ }^{13} \mathrm{C}$ NMR $\left(150.8 \mathrm{MHz}, 298 \mathrm{~K}, \mathrm{C}_{6} \mathrm{D}_{5} \mathrm{CD}_{3}\right): \delta=9.4\left(\mathrm{Zr}-\mathrm{CH}_{3}\right), 23.0\left(\mathrm{CH}_{3} \mathrm{C}-\mathrm{Zr}\right), 25.7$ $\left(\mathrm{CH}_{3}\right), 29.9\left(\mathrm{CH}_{3}\right.$ in $\left.{ }^{t} \mathrm{Bu}\right), 30.6\left(\mathrm{CH}_{2}\right), 48.4\left(\mathrm{CH}_{3} \mathrm{C}\right), 61.6\left(\mathrm{Me}_{3} \mathrm{C}\right.$ in $\left.{ }^{t} \mathrm{Bu}\right), 97.4(\mathrm{C}-2$ in Cp), 106.6 (C-5 in Cp, the same side with the cyclobutylene bridge), 107.8 (C-4 in Cp), 109.0 (C-3 in Cp), 132.8 (C-1 in Cp), 236.1 (N=C-Zr).

${ }^{\mathbf{1}} \mathbf{H},{ }^{\mathbf{1 3}} \mathbf{C}$-GHSQC $\left(599.7 \mathrm{MHz} / 150.8 \mathrm{MHz}, 298 \mathrm{~K}, \mathrm{C}_{6} \mathrm{D}_{5} \mathrm{CD}_{3}\right): \delta\left({ }^{1} \mathrm{H}\right) / \delta\left({ }^{13} \mathrm{C}\right)=0.22 /$ $9.4\left(\mathrm{Zr}-\mathrm{CH}_{3} / \mathrm{Zr}-\mathrm{CH}_{3}\right), 1.06 / 29.9\left({ }^{t} \mathrm{Bu} / \mathrm{CH}_{3}\right.$ in $\left.{ }^{t} \mathrm{Bu}\right), 1.19 / 25.7\left(\mathrm{CH}_{3} / \mathrm{CH}_{3}\right), 1.67 /$ $30.6\left(\mathrm{CH}_{3} \mathrm{CCH}_{\text {back }} / \mathrm{CH}_{2}\right), 2.31 / 23.0\left(\mathrm{CH}_{3} \mathrm{C}-\mathrm{Zr} / \mathrm{CH}_{3} \mathrm{C}-\mathrm{Zr}\right), 2.33 / 30.6\left(\mathrm{CH}_{3} \mathrm{CCH}_{\text {front }} /\right.$ $\mathrm{CH}_{2}$ ), 4.93 / 109.0 (H-3 in Cp / C-3 in Cp), 5.33 / 107.8 (H-4 in Cp / C-4 in Cp), 5.49 / 97.4 (H-2 in $\mathrm{Cp} / \mathrm{C}-2$ in $\mathrm{Cp}), 5.88$ / 106.6 (H-5 in Cp / C-5 in Cp).

${ }^{\mathbf{1}} \mathbf{H},{ }^{\mathbf{1 3}} \mathbf{C}$-GHMBC (599.7 MHz / $150.8 \mathrm{MHz}, 298 \mathrm{~K}, \mathrm{C}_{6} \mathrm{D}_{5} \mathrm{CD}_{3}$, selected ${ }^{13} \mathrm{C}$ traces): $\delta$ $\left({ }^{13} \mathrm{C}\right) / \delta\left({ }^{1} \mathrm{H}\right)=48.4 / 1.19,1.67,2.33\left(\mathrm{CH}_{3} \mathrm{C} / \mathrm{CH}_{3}, \mathrm{CH}_{3} \mathrm{CCH}_{\text {back }}, \mathrm{CH}_{3} \mathrm{CCH}_{\text {front }}\right) ; 61.6 /$ $1.06\left(\mathrm{Me}_{3} \mathrm{C}\right.$ in $\left.{ }^{t} \mathrm{Bu} /{ }^{t} \mathrm{Bu}\right) ; 132.8 / 1.19,1.67,2.33,5.49,5.88\left(\mathrm{C}-1\right.$ in $\mathrm{Cp} / \mathrm{CH}_{3}$, $\mathrm{CH}_{3} \mathrm{CCH}_{\text {back }}, \mathrm{CH}_{3} \mathrm{CCH}_{\text {front }}, \mathrm{H}-2$ in $\mathrm{Cp}, \mathrm{H}-5$ in $\left.\mathrm{Cp}\right) ; 236.1 / 0.22,2.31(\mathrm{~N}=\mathrm{C}-\mathrm{Zr}$ / $\left.\mathrm{Zr}-\mathrm{CH}_{3}, \mathrm{CH}_{3} \mathrm{C}-\mathrm{Zr}\right)$.

${ }^{1} \mathbf{H}\left\{{ }^{1} \mathbf{H}\right\}$-NOE $\left(599.7 \mathrm{MHz}, 298 \mathrm{~K}, \mathrm{C}_{6} \mathrm{D}_{5} \mathrm{CD}_{3}\right): \delta\left({ }^{1} \mathrm{H}\right)_{\text {irradiation }} / \delta\left({ }^{1} \mathrm{H}\right)_{\text {response }}=0.22 /$ 5.33, $5.88\left(\mathrm{Zr}-\mathrm{CH}_{3} / \mathrm{H}-4\right.$ in $\mathrm{Cp}, \mathrm{H}-5$ in $\left.\mathrm{Cp}\right) ; 1.06$ / 0.22, 2.31, 4.93, $5.33\left({ }^{t} \mathrm{Bu} / \mathrm{Zr}-\mathrm{CH}_{3}\right.$, $\mathrm{CH}_{3} \mathrm{C}-\mathrm{Zr}, \mathrm{H}-3$ in $\mathrm{Cp}, \mathrm{H}-4$ in $\left.\mathrm{Cp}\right) ; 1.19$ / 1.67, $5.49\left(\mathrm{CH}_{3} / \mathrm{CH}_{3} \mathrm{CCH}_{\text {back }}\right.$, H-2 in $\left.\mathrm{Cp}\right)$; 1.67 / 1.19, $2.33\left(\mathrm{CH}_{3} \mathrm{CCH}_{\text {back }} / \mathrm{CH}_{3}, \mathrm{CH}_{3} \mathrm{CCH}_{\text {front }}\right) ; 2.31$ / 4.93, $5.49\left(\mathrm{CH}_{3} \mathrm{C}-\mathrm{Zr} / \mathrm{H}-3\right.$ in $\mathrm{Cp}, \mathrm{H}-2$ in $\mathrm{Cp}) ; 2.33$ / 1.67, $5.88\left(\mathrm{CH}_{3} \mathrm{CCH}_{\text {front }} / \mathrm{CH}_{3} \mathrm{CCH}_{\text {back }}, \mathrm{H}-5\right.$ in $\left.\mathrm{Cp}\right) ; 4.93$ / 
2.31, 5.49, 5.33 (H-3 in $\mathrm{Cp} / \mathrm{CH}_{3} \mathrm{C}-\mathrm{Zr}, \mathrm{H}-2$ in $\mathrm{Cp}, \mathrm{H}-4$ in $\left.\mathrm{Cp}\right)$; 5.33 / 0.22, 4.93, 5.88 (H-4 in Cp / Zr-CH 3 , H-3 in Cp, H-5 in Cp); 5.49 / 1.19, 4.93 (H-2 in Cp / $\mathrm{CH}_{3}, \mathrm{H}-3$ in $\mathrm{Cp})$

24-anti $\left(\mathrm{Zr}-\mathrm{CH}_{3}\right.$ is at the opposite side to the cyclobutylene bridge, major product):

${ }^{1} \mathbf{H}$ NMR $\left(599.7 \mathrm{MHz}, 298 \mathrm{~K}, \mathrm{C}_{6} \mathrm{D}_{5} \mathrm{CD}_{3}\right): \delta=0.11$ (s, 3H, $\mathrm{Zr}-\mathrm{CH}_{3}$, the opposite side to the cyclobutylene bridge), $1.03\left(\mathrm{~s}, 9 \mathrm{H},{ }^{t} \mathrm{BuN}=\mathrm{C}-\mathrm{Zr}\right), 1.16\left(\mathrm{~s}, 6 \mathrm{H}, \mathrm{CH}_{3}\right), 1.77\left(\mathrm{AA}^{\prime} \mathrm{BB}\right.$ ', 2H, $\mathrm{CH}_{3} \mathrm{CCH}_{\text {back }}$ ), 2.39 (s, 3H, $\mathrm{CH}_{3} \mathrm{C}-\mathrm{Zr}$ ), 2.43 (AA'BB', 2H, $\mathrm{CH}_{3} \mathrm{CCH}_{\text {front }}$ ), 4.56 (m, 2H, H-4 in Cp), 5.45 (m, 2H, H-2 in Cp), 5.70 (m, 2H, H-5 in Cp, the same side with the cyclobutylene bridge), 5.90 (m, 2H, H-3 in Cp).

${ }^{13}$ C NMR (150.8 MHz, 298K, $\left.\mathrm{C}_{6} \mathrm{D}_{5} \mathrm{CD}_{3}\right): \delta=8.6\left(\mathrm{Zr}-\mathrm{CH}_{3}\right), 23.0\left(\mathrm{CH}_{3} \mathrm{C}-\mathrm{Zr}\right), 26.0$ $\left(\mathrm{CH}_{3}\right), 29.9\left(\mathrm{CH}_{3}\right.$ in $\left.{ }^{t} \mathrm{Bu}\right), 30.9\left(\mathrm{CH}_{2}\right), 48.6\left(\mathrm{CH}_{3} \mathrm{C}\right), 61.5\left(\mathrm{Me}_{3} \mathrm{C}\right.$ in $\left.{ }^{t} \mathrm{Bu}\right), 98.5(\mathrm{C}-5$ in Cp, the same side with the cyclobutylene bridge), 101.3 (C-2 in Cp), 105.0 (C-4 in Cp), 116.2 (C-3 in $\mathrm{Cp}$ ), 132.7 (C-1 in $\mathrm{Cp}), 235.2$ (N=C-Zr).

${ }^{1} \mathbf{H},{ }^{13} \mathbf{C}-G H S Q C\left(599.7 \mathrm{MHz} / 150.8 \mathrm{MHz}, 298 \mathrm{~K}, \mathrm{C}_{6} \mathrm{D}_{5} \mathrm{CD}_{3}\right): \delta\left({ }^{1} \mathrm{H}\right) / \delta\left({ }^{13} \mathrm{C}\right)=0.11 /$ $8.6\left(\mathrm{Zr}-\mathrm{CH}_{3} / \mathrm{Zr}-\mathrm{CH}_{3}\right), 1.03 / 29.9\left({ }^{t} \mathrm{Bu} / \mathrm{CH}_{3}\right.$ in $\left.{ }^{t} \mathrm{Bu}\right), 1.16 / 26.0\left(\mathrm{CH}_{3} / \mathrm{CH}_{3}\right), 1.77$ / $30.9\left(\mathrm{CH}_{3} \mathrm{CCH}_{\text {back }} / \mathrm{CH}_{2}\right), 2.39$ / $23.0\left(\mathrm{CH}_{3} \mathrm{C}-\mathrm{Zr} / \mathrm{CH}_{3} \mathrm{C}-\mathrm{Zr}\right), 2.43$ / $30.9\left(\mathrm{CH}_{3} \mathrm{CCH}_{\text {front }} /\right.$ $\left.\mathrm{CH}_{2}\right), 4.56$ / 105.0 (H-4 in Cp / C-4 in Cp), 5.45 / 101.3 (H-2 in Cp / C-2 in Cp), 5.70 / 98.5 (H-5 in Cp / C-5 in Cp), 5.90 / 116.2 (H-3 in Cp / C-3 in Cp).

${ }^{\mathbf{1}} \mathbf{H},{ }^{\mathbf{1 3}} \mathbf{C}$-GHMBC (599.7 MHz / $150.8 \mathrm{MHz}, 298 \mathrm{~K}, \mathrm{C}_{6} \mathrm{D}_{5} \mathrm{CD}_{3}$, selected ${ }^{13} \mathrm{C}$ traces): $\delta$ $\left({ }^{13} \mathrm{C}\right) / \delta\left({ }^{1} \mathrm{H}\right)=48.6 / 1.16,1.77,2.43\left(\mathrm{CH}_{3} \mathrm{C} / \mathrm{CH}_{3}, \mathrm{CH}_{3} \mathrm{CCH}_{\text {back }}, \mathrm{CH}_{3} \mathrm{CCH}_{\text {front }}\right) ; 61.5 /$ $1.03\left(\mathrm{Me}_{3} \mathrm{C}\right.$ in $\left.{ }^{t} \mathrm{Bu} /{ }^{t} \mathrm{Bu}\right) ; 132.7 / 1.16,1.77,2.43,5.45,5.70\left(\mathrm{C}-1\right.$ in $\mathrm{Cp} / \mathrm{CH}_{3}$, $\mathrm{CH}_{3} \mathrm{CCH}_{\text {back }}, \mathrm{CH}_{3} \mathrm{CCH}_{\text {front }}, \mathrm{H}-2$ in $\mathrm{Cp}, \mathrm{H}-5$ in $\left.\mathrm{Cp}\right), 235.2 / 0.11,2.39(\mathrm{~N}=\mathrm{C}-\mathrm{Zr}$ / 
$\mathrm{Zr}-\mathrm{CH}_{3}, \mathrm{CH}_{3} \mathrm{C}-\mathrm{Zr}$ ).

${ }^{1} \mathbf{H}\left\{{ }^{1} \mathbf{H}\right\}$-NOE $\left(599.7 \mathrm{MHz}, 298 \mathrm{~K}, \mathrm{C}_{6} \mathrm{D}_{5} \mathrm{CD}_{3}\right): \delta\left({ }^{1} \mathrm{H}\right)_{\text {irradiation }} / \delta\left({ }^{1} \mathrm{H}\right)_{\text {response }}=0.11 /$ 5.45, $5.90\left(\mathrm{Zr}-\mathrm{CH}_{3} / \mathrm{H}-2\right.$ in $\mathrm{Cp}, \mathrm{H}-3$ in $\left.\mathrm{Cp}\right) ; 1.03$ / 0.11, 2.39, $4.56\left({ }^{t} \mathrm{Bu} / \mathrm{Zr}-\mathrm{CH}_{3}\right.$, $\mathrm{CH}_{3} \mathrm{C}-\mathrm{Zr}, \mathrm{H}-4$ in $\left.\mathrm{Cp}\right) ; 1.16$ / 1.77, $5.45\left(\mathrm{CH}_{3} / \mathrm{CH}_{3} \mathrm{CCH}_{\text {back }}\right.$, H-2 in $\left.\mathrm{Cp}\right) ; 1,77$ / 1.16, $2.43\left(\mathrm{CH}_{3} \mathrm{CCH}_{\text {back }} / \mathrm{CH}_{3}, \mathrm{CH}_{3} \mathrm{CCH}_{\text {front }}\right) ; 2.39$ / 1.03, 4.56, $5.70\left(\mathrm{CH}_{3} \mathrm{C}-\mathrm{Zr} /{ }^{t} \mathrm{Bu}, \mathrm{H}-4\right.$ in Cp, H-5 in Cp); 2.43 / 1.77, $5.70\left(\mathrm{CH}_{3} \mathrm{CCH}_{\text {front }} / \mathrm{CH}_{3} \mathrm{CCH}_{\text {back }}, \mathrm{H}-5\right.$ in $\left.\mathrm{Cp}\right) ; 4.56$ / 2.39, 5.70, 5.90 (H-4 in Cp / $\mathrm{CH}_{3} \mathrm{C}-\mathrm{Zr}, \mathrm{H}-5$ in $\mathrm{Cp}, \mathrm{H}-3$ in $\left.\mathrm{Cp}\right)$; 5.45 / 0.11, 1.16, 5.90 (H-2 in $\mathrm{Cp} / \mathrm{Zr}-\mathrm{CH}_{3}, \mathrm{CH}_{3}, \mathrm{H}-3$ in $\left.\mathrm{Cp}\right) ; 5.70$ / 2.39, 2.43, 4.56 (H-5 in $\mathrm{Cp} / \mathrm{CH}_{3} \mathrm{C}-\mathrm{Zr}$, $\mathrm{CH}_{3} \mathrm{CCH}_{\text {front }}, \mathrm{H}-4$ in $\mathrm{Cp}$ ). 
General procedure for preparation of samples for variable-temperature NMR experiments:

$25 \mathrm{mg}$ of the respective dimethyl or diphenyl ansa-zirconocene complex was added into a NMR tube, and then it was dissolved by several drops of $\mathrm{d}_{8}$-toluene. The solution was cooled to $-78{ }^{\circ} \mathrm{C}$ and appropriate amount of ${ }^{t} \mathrm{BuNC}$ in $0.4 \mathrm{ml}$ of $\mathrm{d}_{8}$-toluene, which was also first cooled down to $-78^{\circ} \mathrm{C}$, was added into the NMR tube slowly. The mixture was stirred mechanically until it became homogeneous. Then the NMR tube was sealed at $-78{ }^{\circ} \mathrm{C}$ and kept at the same temperature for the NMR measurement. The

${ }^{1} \mathrm{H}$ NMR of the sample was measured every 2 min at the corresponding temperature and the measurement was last for $2 \mathrm{~h}$.

Preparation of kinetic products of $\eta^{2}$-N-tert-butyliminoacetyl methyl ansa-bisindenyl zirconium complexes 25

At $213 \mathrm{~K}$, there were only two kinetic products, and among them the major product isomerized to the major thermodynamic one and the minor product isomerized to the minor thermodynamic one. Some of the important ${ }^{1} \mathrm{H}$ NMR signals were selected for each kinetic product. According to ${ }^{1} \mathrm{H}$ NMR spectrum, the ratio between 25-syn and 25-anti is $58: 42$

25-syn (Zr-Me is at the same side with the cyclobutylene bridge and the $\mathrm{N}$ atom is outside, major product): ${ }^{1} \mathrm{H}$ NMR $\left(599.7 \mathrm{MHz}, 213 \mathrm{~K}, \mathrm{C}_{6} \mathrm{D}_{5} \mathrm{CD}_{3}\right): \delta 0.06(\mathrm{~s}, 3 \mathrm{H}$, $\left.\mathrm{Zr}-\mathrm{CH}_{3}\right), 1.14\left(\mathrm{~s}, 9 \mathrm{H},{ }^{t} \mathrm{BuN}=\mathrm{C}-\mathrm{Zr}\right), 1.34\left(\mathrm{~s}, 6 \mathrm{H}, \mathrm{CH}_{3}\right), 1.72 \quad\left(\mathrm{AA}^{\prime} \mathrm{BB} ', 2 \mathrm{H}\right.$, $\mathrm{CH}_{3} \mathrm{CCH}_{\text {back }}$ ), 1.41 (s, 3H CH $3 \mathrm{C}-\mathrm{Zr}$ ), 2.37 (AA'BB', 2H $\mathrm{CH}_{3} \mathrm{CCH}_{\text {front }}$ ), 5.92 (d, J = 2 $\mathrm{Hz}, 2 \mathrm{H}, 3-\mathrm{H}$ in indenyl), $6.05(\mathrm{~d}, \mathrm{~J}=2 \mathrm{~Hz}, 2 \mathrm{H}, 1-\mathrm{H}$ in indenyl, the same side with the 
cyclobutylene bridge).

25-anti ( $\mathrm{Zr}-\mathrm{Me}$ is at the opposite side to the cyclobutylene bridge and the $\mathrm{N}$ atom is outside, minor product): ${ }^{1} \mathrm{H}$ NMR $\left(599.7 \mathrm{MHz}, 213 \mathrm{~K}, \mathrm{C}_{6} \mathrm{D}_{5} \mathrm{CD}_{3}\right): \delta-0.28(\mathrm{~s}, 3 \mathrm{H}$, $\mathrm{Zr}-\mathrm{CH}_{3}$, the opposite side to the cyclobutylene bridge), 1.17 (s, 9H, ${ }^{t} \mathrm{BuN}=\mathrm{C}-\mathrm{Zr}$ ), 1.28 (s, 6H, $\mathrm{CH}_{3}$ ), 1.88 (AA'BB', 2H, $\mathrm{CH}_{3} \mathrm{CCH}_{\text {back }}$ ), 1.45 (s, 3H, $\mathrm{CH}_{3} \mathrm{C}-\mathrm{Zr}$ ), 2.66 (AA'BB', $\left.2 \mathrm{H}, \mathrm{CH}_{3} \mathrm{CCH}_{\text {front }}\right), 5.56(\mathrm{~d}, \mathrm{~J}=2 \mathrm{~Hz}, 2 \mathrm{H}, 3-\mathrm{H}$ in indenyl), $6.14(\mathrm{~d}, \mathrm{~J}=2 \mathrm{~Hz}, 2 \mathrm{H}, 1-\mathrm{H}$ in indenyl, the same side with the cyclobutylene bridge).

Preparation of kinetic products of $\eta^{2}$-N-tert-butyliminobenzoyl phenyl ansa-bisindenyl zirconium complexes 19

At $213 \mathrm{~K}$, there were only two kinetic products, and among them the major product isomerized to the major thermodynamic one and the minor product isomerized to the minor thermodynamic one. Some of the important ${ }^{1} \mathrm{H}$ NMR signals were selected for each kinetic product. According to ${ }^{1} \mathrm{H}$ NMR spectrum, the ratio between 19-syn and 19-anti is $63: 37$

19-syn ( $\mathrm{Zr}-\mathrm{Ph}$ is at the same side with the cyclobutylene bridge and the $\mathrm{N}$ atom is outside, major product): ${ }^{1} \mathrm{H}$ NMR $\left(599.7 \mathrm{MHz}, 213 \mathrm{~K}, \mathrm{C}_{6} \mathrm{D}_{5} \mathrm{CD}_{3}\right): \delta 1.21(\mathrm{~s}, 9 \mathrm{H}$, $\left.{ }^{t} \mathrm{BuN}=\mathrm{C}-\mathrm{Zr}\right), 1.35\left(\mathrm{~s}, 6 \mathrm{H}, \mathrm{CH}_{3}\right), 1.75\left(\mathrm{AA}^{\prime} \mathrm{BB}\right.$ ', 2H, $\left.\mathrm{CH}_{3} \mathrm{CCH}_{\text {back }}\right), 2.46\left(\mathrm{AA}^{\prime} \mathrm{BB}\right.$ ', $2 \mathrm{H}$ $\left.\mathrm{CH}_{3} \mathrm{CCH}_{\text {front }}\right), 6.17(\mathrm{~d}, \mathrm{~J}=2 \mathrm{~Hz}, 2 \mathrm{H}, 3-\mathrm{H}$ in indenyl), $6.28(\mathrm{~d}, \mathrm{~J}=2 \mathrm{~Hz}, 2 \mathrm{H}, 1-\mathrm{H}$ in indenyl, the same side with the cyclobutylene bridge).

19-anti ( $\mathrm{Zr}-\mathrm{Ph}$ is at the opposite side to the cyclobutylene bridge and the $\mathrm{N}$ atom is outside, minor product): ${ }^{1} \mathrm{H}$ NMR $\left(599.11 \mathrm{MHz}, 213 \mathrm{~K}, \mathrm{C}_{6} \mathrm{D}_{5} \mathrm{CD}_{3}\right): \delta 1.23(\mathrm{~s}, 9 \mathrm{H}$, $\left.{ }^{t} \mathrm{BuN}=\mathrm{C}-\mathrm{Zr}\right), 1.28\left(\mathrm{~s}, 6 \mathrm{H}, \mathrm{CH}_{3}\right), 1.89\left(\mathrm{AA}^{\prime} \mathrm{BB}\right.$ ', 2H, $\left.\mathrm{CH}_{3} \mathrm{CCH}_{\text {back }}\right), 2.64\left(\mathrm{AA}^{\prime} \mathrm{BB}\right.$ ', $2 \mathrm{H}$, 
$\left.\mathrm{CH}_{3} \mathrm{CCH}_{\text {front }}\right), 5.98(\mathrm{~d}, \mathrm{~J}=2 \mathrm{~Hz}, 2 \mathrm{H}, 3-\mathrm{H}$ in indenyl), $6.22(\mathrm{~d}, \mathrm{~J}=2 \mathrm{~Hz}, 2 \mathrm{H}, 1-\mathrm{H}$ in indenyl, the same side with the cyclobutylene bridge).

\section{Preparation of kinetic products of $\eta^{2}$-N-tert-butyliminobenzoyl phenyl} ansa-biscyclopentadienyl zirconium complexes 21,22

The isomerization happened slowly even at $203 \mathrm{~K}$, therefore there were four isomers: two kinetic products $\mathbf{2 1}$ and two thermodynamic ones $\mathbf{2 2}$. The major kinetic product isomerized to the major thermodynamic one and the minor kinetic product isomerized to the minor thermodynamic one. Some of the important ${ }^{1} \mathrm{H}$ NMR signals were selected for each kinetic product. According to the ${ }^{1} \mathrm{H}$ NMR the ratio of 21-syn :21-anti: 22-syn :22-anti is $18: 61: 9: 12$.

21-syn ( $\mathrm{Zr}-\mathrm{Ph}$ is at the same side with the cyclobutylene bridge, minor product): ${ }^{1} \mathrm{H}$ NMR (599.11 MHz, 203K, $\left.\mathrm{C}_{6} \mathrm{D}_{5} \mathrm{CD}_{3}\right): \delta 0.97\left(\mathrm{~s}, 9 \mathrm{H},{ }^{t} \mathrm{BuN}=\mathrm{C}-\mathrm{Zr}\right), 1.28\left(\mathrm{~s}, 6 \mathrm{H}, \mathrm{CH}_{3}\right)$, 1.68 (AA'BB', 2H, $\mathrm{CH}_{3} \mathrm{CCH}_{\text {back }}$ ), 2.28 (AA'BB', 2H, $\mathrm{CH}_{3} \mathrm{CCH}_{\text {front }}$ ), 5.03 (m, 2H, in Cp), 5.84 (m, 2H, in Cp), 5.89 (m, 2H, in $\mathrm{Cp}), 5.96$ (m, 2H, in Cp).

21-anti ( $\mathrm{Zr}-\mathrm{Ph}$ is at the opposite side to the cyclobutylene bridge, major product): ${ }^{1} \mathrm{H}$ NMR (599.11 MHz, 203K, $\left.\mathrm{C}_{6} \mathrm{D}_{5} \mathrm{CD}_{3}\right): \delta 1.00\left(\mathrm{~s}, 9 \mathrm{H},{ }^{t} \mathrm{BuN}=\mathrm{C}-\mathrm{Zr}\right), 1.19$ (s, 6H, $\mathrm{CH}_{3}$ ), 1.83 (AA'BB', 2H, $\mathrm{CH}_{3} \mathrm{CCH}_{\text {back }}$ ), 2.53 (AA'BB', 2H, $\mathrm{CH}_{3} \mathrm{CCH}_{\text {front }}$ ), 4.96 (m, 2H, in Cp), 5.47 (m, 2H, in Cp), 5.99 (m, 2H, in $\mathrm{Cp}), 6.05$ (m, 2H, in Cp), 7.84 (m, 2H, $o-\mathrm{H}$ in $\mathrm{Ph}-\mathrm{Zr})$.

22-syn $(\mathrm{Zr}-\mathrm{Ph}$ is at the same side with the cyclobutylene bridge, and $\mathrm{N}$ atom is inside, minor product): ${ }^{1} \mathrm{H}$ NMR (599.11 MHz, 203K, $\left.\mathrm{C}_{6} \mathrm{D}_{5} \mathrm{CD}_{3}\right): \delta 1.52$ (AA'BB', 2H, 
$\mathrm{CH}_{3} \mathrm{CCH}_{\text {back }}$ ), 2.15 (AA'BB', 2H, $\mathrm{CH}_{3} \mathrm{CCH}_{\text {front }}$ ), 5.32 (m, 2H, in $\left.\mathrm{Cp}\right), 5.44$ (m, 2H, in $\mathrm{Cp}), 5.66$ (m, 2H, in $\mathrm{Cp}), 6.17$ (m, 2H, in $\mathrm{Cp}), 8.07$ (m, 2H, $o-\mathrm{H}$ in $\mathrm{Ph}-\mathrm{Zr})$.

22-anti $(\mathrm{Zr}-\mathrm{Ph}$ is at the opposite side to the cyclobutylene bridge, and $\mathrm{N}$ atom is inside, major product): ${ }^{1} \mathrm{H}$ NMR $\left(599.11 \mathrm{MHz}, 203 \mathrm{~K}, \mathrm{C}_{6} \mathrm{D}_{5} \mathrm{CD}_{3}\right): \delta 0.94\left(\mathrm{~s}, 9 \mathrm{H},{ }^{t} \mathrm{BuN}=\mathrm{C}-\mathrm{Zr}\right)$, 1.49 (AA'BB', 2H, $\mathrm{CH}_{3} \mathrm{CCH}_{\text {back }}$ ), 2.08 (AA'BB', 2H, $\mathrm{CH}_{3} \mathrm{CCH}_{\text {front }}$ ), 4.91 (m, 2H, in Cp), 5.49 (m, 2H, in Cp), 5.85 (m, 2H, in $\mathrm{Cp}), 6.20$ (m, 2H, in $\mathrm{Cp}$ ).

Preparation of kinetic products of $\eta^{2}$-N-tert-butyliminoacetyl methyl ansa-biscyclopentadienyl zirconium complexes 23,24

The isomerization happened even at $203 \mathrm{~K}$, therefore there were four isomers: two kinetic products 23 and two thermodynamic ones $\mathbf{2 4}$. The major kinetic product isomerized to the major thermodynamic one and the minor kinetic product isomerized to the minor thermodynamic one. Some of the important ${ }^{1} \mathrm{H}$ NMR signals were selected for each kinetic product. According to the ${ }^{1} \mathrm{H}$ NMR the ratio of 23-syn : 23-anti : 24-syn : 24-anti is $2: 21: 30: 47$.

23-syn $\left(\mathrm{Zr}-\mathrm{CH}_{3}\right.$ is at the same side with the cyclobutylene bridge, minor product): ${ }^{1} \mathrm{H}$ NMR (599.11 MHz, 203K, $\left.\mathrm{C}_{6} \mathrm{D}_{5} \mathrm{CD}_{3}\right): \delta 0.57$ (s, 3H Zr-CH 3 ), $0.95\left(\mathrm{~s}, 9 \mathrm{H}{ }^{t} \mathrm{BuN}=\mathrm{C}-\mathrm{Zr}\right.$ ), $5.14(\mathrm{~m}, 2 \mathrm{H}$, in $\mathrm{Cp}), 5.71(\mathrm{~m}, 2 \mathrm{H}$, in $\mathrm{Cp}), 5.82(\mathrm{~m}, 2 \mathrm{H}$, in $\mathrm{Cp}), 6.09(\mathrm{~m}, 2 \mathrm{H}$, in $\mathrm{Cp})$. 23-anti $\left(\mathrm{Zr}-\mathrm{CH}_{3}\right.$ is at the opposite side to the cyclobutylene bridge, major product): ${ }^{1} \mathrm{H}$ NMR (599.11 MHz, 203K, $\left.\mathrm{C}_{6} \mathrm{D}_{5} \mathrm{CD}_{3}\right): \delta 0.49$ (s, 3H, $\mathrm{Zr}-\mathrm{CH}_{3}$, the opposite side to the cyclobutylene bridge), $1.00\left(\mathrm{~s}, 9 \mathrm{H},{ }^{t} \mathrm{BuN}=\mathrm{C}-\mathrm{Zr}\right), 1.18\left(\mathrm{~s}, 6 \mathrm{H}, \mathrm{CH}_{3}\right), 2.15(\mathrm{~s}, 3 \mathrm{H}$, $\left.\mathrm{CH}_{3} \mathrm{C}-\mathrm{Zr}\right), 4.82$ (m, 2H, in $\left.\mathrm{Cp}\right), 5.37$ (m, 2H, in $\left.\mathrm{Cp}\right), 5.79(\mathrm{~m}, 2 \mathrm{H}$, in $\mathrm{Cp}), 5.91$ (m, 2H in $\mathrm{Cp}$ ). 
24-syn $\left(\mathrm{Zr}-\mathrm{CH}_{3}\right.$ is at the same side with the cyclobutylene bridge, and $\mathrm{N}$ atom is inside, minor product): ${ }^{1} \mathrm{H}$ NMR (599.11 MHz, 203K, $\left.\mathrm{C}_{6} \mathrm{D}_{5} \mathrm{CD}_{3}\right): \delta 0.42\left(\mathrm{~s}, 3 \mathrm{H} \mathrm{Zr}-\mathrm{CH}_{3}\right), 1.06$ (s, 9H $\left.{ }^{t} \mathrm{BuN}=\mathrm{C}-\mathrm{Zr}\right), 1.18\left(\mathrm{~s}, 6 \mathrm{H}, \mathrm{CH}_{3}\right), 1.67\left(\mathrm{AA}^{\prime} \mathrm{BB}\right.$ ', $\left.2 \mathrm{H}, \mathrm{CH}_{3} \mathrm{CCH}_{\text {back }}\right), 2.23(\mathrm{~s}, 3 \mathrm{H}$, $\mathrm{CH}_{3} \mathrm{C}-\mathrm{Zr}$ ), 2.33 (AA'BB', 2H, $\mathrm{CH}_{3} \mathrm{CCH}_{\text {front }}$ ), 4.98 (m, 2H, in $\left.\mathrm{Cp}\right), 5.31$ (m, 2H, in Cp), $5.37(\mathrm{~m}, 2 \mathrm{H}$, in $\mathrm{Cp}), 5.93(\mathrm{~m}, 2 \mathrm{H}$, in $\mathrm{Cp})$.

24-anti $\left(\mathrm{Zr}-\mathrm{CH}_{3}\right.$ is at the opposite side to the cyclobutylene bridge, and $\mathrm{N}$ atom is inside, major product): ${ }^{1} \mathrm{H}$ NMR $\left(599.11 \mathrm{MHz}, 203 \mathrm{~K}, \mathrm{C}_{6} \mathrm{D}_{5} \mathrm{CD}_{3}\right): \delta 0.27(\mathrm{~s}, 3 \mathrm{H}$, $\mathrm{Zr}-\mathrm{CH}_{3}$, the opposite side to the cyclobutylene bridge), $1.02\left(\mathrm{~s}, 9 \mathrm{H},{ }^{t} \mathrm{BuN}=\mathrm{C}-\mathrm{Zr}\right), 1.16$ (s, 6H, $\mathrm{CH}_{3}$ ), 1.80 (AA'BB', 2H, $\mathrm{CH}_{3} \mathrm{CCH}_{\text {back }}$ ), 2.30 (s, 3H, $\mathrm{CH}_{3} \mathrm{C}-\mathrm{Zr}$ ), 2.46 (AA'BB', 2H, $\left.\mathrm{CH}_{3} \mathrm{CCH}_{\text {front }}\right), 4.50(\mathrm{~m}, 2 \mathrm{H}$, in $\mathrm{Cp}), 5.32(\mathrm{~m}, 2 \mathrm{H}$, in $\mathrm{Cp}), 5.68(\mathrm{~m}, 2 \mathrm{H}$, in $\mathrm{Cp}), 6.11$ (m, $2 \mathrm{H}$ in $\mathrm{Cp})$. 


\section{Detailed kinetic data}
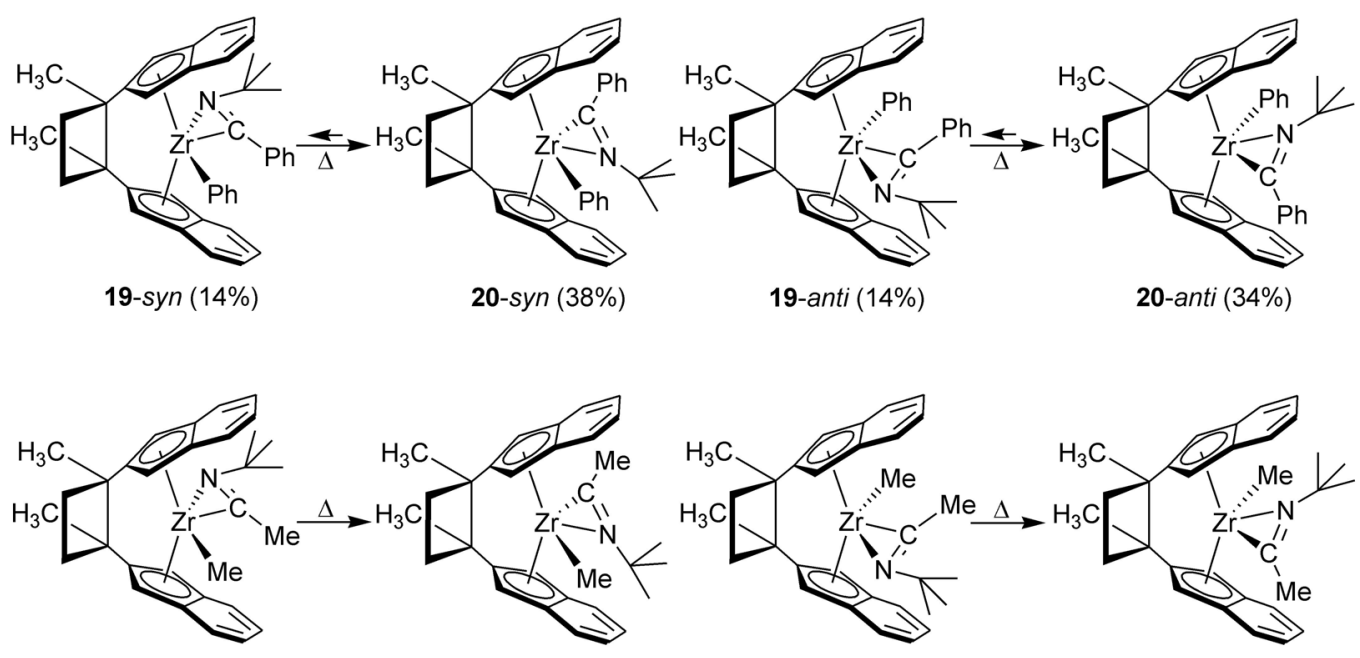

25-syn

17-syn (56\%)

25-anti

17-anti (44\%)

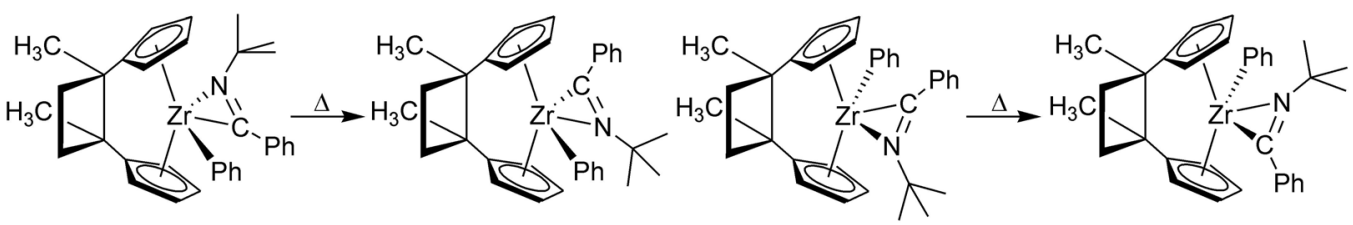

21-syn

22-syn (32\%)

21-anti

22-anti (68\%)

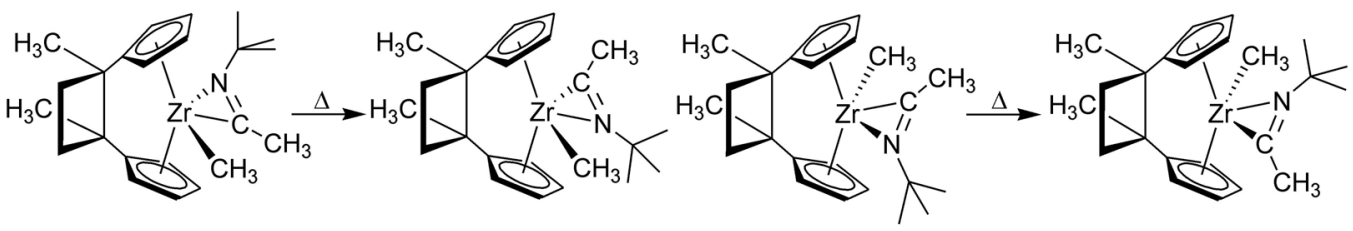

23-syn

24-syn (35\%)

23-anti

24-anti (65\%)

thermodynamic ratio at $298 \mathrm{~K}$

Scheme 6 Thermal isomerization of iminoacyl ansa-zirconocenes

(The ratios in the bracket were calculated according to the ${ }^{1} \mathrm{H}$ NMR of the purified products) 
Several suitable resonances of protons in each complex were selected for integration and different $\tau$ values $\left(=\mathrm{k}^{-1}\left[\mathrm{~s}^{-1}\right]\right)$ were calculated by exponential fit of the kinetic data (the first order) with "vnmr" from Varian. The $\Delta G^{\neq}$rearr and its error of each isomerization were calculated according to the following equations. All the data are compilated in Table $\mathbf{1 .}$

Erying equation:

$$
\Delta G^{\neq}=R T\left[23.759-\ln \left(\frac{k}{T}\right)\right]=R T\left[23.759-\ln \left(\frac{1}{\tau T}\right)\right], k=\frac{1}{\tau}
$$

Law of propagation of error:

$$
\begin{aligned}
& S_{f\left(x_{i}\right)}=\sqrt{\sum_{i=1}^{n}\left(\frac{\partial f\left(x_{i}\right)}{\partial x_{i}}\right)^{2} \cdot S_{x i}{ }^{2}} \\
& S_{\Delta G^{\ddagger}(\tau)}=R T \frac{S_{\tau}}{\tau}, S_{k(\tau)}=\frac{S_{\tau}}{\tau^{2}}
\end{aligned}
$$

\begin{tabular}{|c|c|c|c|c|}
\hline${ }^{\mathrm{a}}$ Complex & $\delta\left({ }^{1} \mathrm{H}\right.$ NMR $)$ & $\mathrm{T} / \mathrm{K}$ & $\mathrm{k} / \mathrm{s}^{-1}$ & $\Delta \mathrm{G}_{\text {rearr }}^{\neq} / \mathrm{kJ}(\mathrm{kcal}) \cdot \mathrm{mol}^{-1}$ \\
\hline 19-syn & 1.37 & \multirow{6}{*}{258} & $(1.90 \pm 0.02) \times 10^{-4}$ & $(81.3 \pm 0.02)(19.4 \pm 0.006)$ \\
\hline 19-syn & 2.54 & & $(1.80 \pm 0.03) \times 10^{-4}$ & $(81.4 \pm 0.04)(19.4 \pm 0.008)$ \\
\hline $20-s y n$ & 1.09 & & $(1.59 \pm 0.01) \times 10^{-4}$ & $(81.6 \pm 0.02)(19.5 \pm 0.004)$ \\
\hline 20-syn & 0.67 & & $(1.56 \pm 0.009) \times 10^{-4}$ & $(81.7 \pm 0.01)(19.5 \pm 0.003)$ \\
\hline 19-anti & 2.68 & & $(3.03 \pm 0.04) \times 10^{-4}$ & $(80.2 \pm 0.03)(19.2 \pm 0.008)$ \\
\hline 20-anti & 1.13 & & $(2.71 \pm 0.02) \times 10^{-4}$ & $(80.5 \pm 0.02)(19.2 \pm 0.004)$ \\
\hline${ }^{\mathrm{b}}$ Complex & $\delta\left({ }^{1} \mathrm{H}\right.$ NMR $)$ & $\mathrm{T} / \mathrm{K}$ & $\mathrm{k} / \mathrm{s}^{-1}$ & $\Delta \mathrm{G}_{\text {rearr }}^{\neq} / \mathrm{kJ}(\mathrm{kcal}) \cdot \mathrm{mol}^{-1}$ \\
\hline 19-syn & 1.37 & \multirow{9}{*}{258} & $(2.02 \pm 0.03) \times 10^{-4}$ & $(81.1 \pm 0.03)(19.4 \pm 0.007)$ \\
\hline 19-syn & 2.54 & & $(1.91 \pm 0.04) \times 10^{-4}$ & $(81.2 \pm 0.04)(19.4 \pm 0.01)$ \\
\hline 20-syn & 1.09 & & $(1.62 \pm 0.02) \times 10^{-4}$ & $(81.6 \pm 0.03)(19.5 \pm 0.007)$ \\
\hline 20-syn & 0.67 & & $(1.59 \pm 0.02) \times 10^{-4}$ & $(81.6 \pm 0.03)(19.5 \pm 0.008)$ \\
\hline $20-s y n$ & 2.45 & & $(1.70 \pm 0.03) \times 10^{-4}$ & $(81.5 \pm 0.04)(19.5 \pm 0.009)$ \\
\hline 19-anti & 2.68 & & $(3.45 \pm 0.09) \times 10^{-4}$ & $(80.0 \pm 0.05)(19.1 \pm 0.01)$ \\
\hline 19-anti & 1.91 & & $(3.55 \pm 0.16) \times 10^{-4}$ & $(79.9 \pm 0.1)(19.1 \pm 0.02)$ \\
\hline 19-anti & 6.05 & & $(4.32 \pm 0.12) \times 10^{-4}$ & $(79.5 \pm 0.06)(19.1 \pm 0.01)$ \\
\hline 20-anti & 1.13 & & $(2.86 \pm 0.04) \times 10^{-4}$ & $(80.4 \pm 0.03)(19.2 \pm 0.006)$ \\
\hline${ }^{\mathrm{a}}$ Complex & $\delta\left({ }^{1} \mathrm{H}\right.$ NMR $)$ & $\mathrm{T} / \mathrm{K}$ & $\mathrm{k} / \mathrm{s}^{-1}$ & $\Delta \mathrm{G}_{\text {rearr }}^{\neq} / \mathrm{kJ}(\mathrm{kcal}) \cdot \mathrm{mol}^{-1}$ \\
\hline $25-s y n$ & 0.036 & 243 & $(3.15 \pm 0.01) \times 10^{-4}$ & $(75.4 \pm 0.006)(18.0 \pm 0.001)$ \\
\hline
\end{tabular}

Table 1. Kinetic data and $\Delta \mathrm{G}^{\ddagger}$ from NMR experiments 


\begin{tabular}{|c|c|c|c|c|}
\hline $17-s y n$ & 0.62 & & $(3.18 \pm 0.01) \times 10^{-4}$ & $(75.4 \pm 0.007)(18.0 \pm 0.002)$ \\
\hline 25-anti & -0.30 & & $(3.47 \pm 0.03) \times 10^{-4}$ & $(75.2 \pm 0.02)(18.0 \pm 0.004)$ \\
\hline 17-anti & 0.67 & & $(3.44 \pm 0.02) \times 10^{-4}$ & $(75.2 \pm 0.009)(18.0 \pm 0.002)$ \\
\hline${ }^{\mathrm{a}, \mathrm{c}}$ Complex & $\delta\left({ }^{1} \mathrm{H}\right.$ NMR $)$ & $\mathrm{T} / \mathrm{K}$ & $\mathrm{k} / \mathrm{s}^{-1}$ & $\Delta \mathrm{G}_{\text {rearr }}^{\neq} / \mathrm{kJ}(\mathrm{kcal}) \cdot \mathrm{mol}^{-1}$ \\
\hline $25-s y n$ & 0.037 & \multirow{6}{*}{243} & $(2.95 \pm 0.009) \times 10^{-4}$ & $(75.5 \pm 0.006)(18.0 \pm 0.001)$ \\
\hline $17-s y n$ & 0.42 & & $(3.04 \pm 0.007) \times 10^{-4}$ & $(75.5 \pm 0.005)(18.0 \pm 0.001)$ \\
\hline $17-s y n$ & 0.62 & & $(2.99 \pm 0.02) \times 10^{-4}$ & $(75.5 \pm 0.02)(18.0 \pm 0.004)$ \\
\hline 25-anti & -0.30 & & $(3.15 \pm 0.02) \times 10^{-4}$ & $(75.4 \pm 0.01)(18.0 \pm 0.002)$ \\
\hline 17-anti & -0.35 & & $(3.29 \pm 0.02) \times 10^{-4}$ & $(75.3 \pm 0.01)(18.0 \pm 0.003)$ \\
\hline 17-anti & 0.67 & & $(3.20 \pm 0.03) \times 10^{-4}$ & $(75.4 \pm 0.02)(18.0 \pm 0.005)$ \\
\hline${ }^{\mathrm{b}}$ Complex & $\delta\left({ }^{1} \mathrm{H}\right.$ NMR $)$ & $\mathrm{T} / \mathrm{K}$ & $\mathrm{k} / \mathrm{s}^{-1}$ & $\Delta \mathrm{G}_{\text {rearr }}^{\neq} / \mathrm{kJ}(\mathrm{kcal}) \cdot \mathrm{mol}^{-1}$ \\
\hline $25-s y n$ & -0.049 & \multirow{7}{*}{243} & $(4.64 \pm 0.04) \times 10^{-4}$ & $(74.6 \pm 0.02)(17.8 \pm 0.004)$ \\
\hline $17-s y n$ & 0.60 & & $(4.68 \pm 0.03) \times 10^{-4}$ & $(74.6 \pm 0.01)(17.8 \pm 0.004)$ \\
\hline $17-s y n$ & 2.20 & & $(4.76 \pm 0.03) \times 10^{-4}$ & $(74.6 \pm 0.01)(17.8 \pm 0.003)$ \\
\hline $17-s y n$ & 0.34 & & $(4.65 \pm 0.05) \times 10^{-4}$ & $(74.6 \pm 0.02)(17.8 \pm 0.005)$ \\
\hline 25-anti & -0.39 & & $(4.88 \pm 0.06) \times 10^{-4}$ & $(74.5 \pm 0.02)(17.8 \pm 0.005)$ \\
\hline 17-anti & -0.45 & & $(4.83 \pm 0.05) \times 10^{-4}$ & $(74.5 \pm 0.02)(17.8 \pm 0.005)$ \\
\hline 17-anti & 0.65 & & $(5.00 \pm 0.07) \times 10^{-4}$ & $(74.4 \pm 0.03)(17.8 \pm 0.006)$ \\
\hline${ }^{\mathrm{b}}$ Complex & $\delta\left({ }^{1} \mathrm{H}\right.$ NMR $)$ & $\mathrm{T} / \mathrm{K}$ & $\mathrm{k} / \mathrm{s}^{-1}$ & $\Delta \mathrm{G}_{\text {rearr }}^{\neq} / \mathrm{kJ}(\mathrm{kcal}) \cdot \mathrm{mol}^{-1}$ \\
\hline 21-syn & 5.04 & \multirow{6}{*}{218} & $(1.85 \pm 0.07) \times 10^{-3}$ & $(64.2 \pm 0.07)(15.4 \pm 0.02)$ \\
\hline $22-s y n$ & 8.07 & & $(2.07 \pm 0.09) \times 10^{-3}$ & $(64.0 \pm 0.08)(15.3 \pm 0.02)$ \\
\hline 22-syn & 5.68 & & $(1.62 \pm 0.04) \times 10^{-3}$ & $(64.5 \pm 0.05)(15.4 \pm 0.01)$ \\
\hline 21-anti & 7.84 & & $(6.25 \pm 0.05) \times 10^{-4}$ & $(66.2 \pm 0.02)(15.8 \pm 0.004)$ \\
\hline 21-anti & 2.54 & & $(6.30 \pm 0.08) \times 10^{-4}$ & $(66.2 \pm 0.02)(15.8 \pm 0.005)$ \\
\hline 22-anti & 5.52 & & $(6.25 \pm 0.05) \times 10^{-4}$ & $(66.2 \pm 0.02)(15.8 \pm 0.004)$ \\
\hline${ }^{\mathrm{b}}$ Complex & $\delta\left({ }^{1} \mathrm{H}\right.$ NMR $)$ & $\mathrm{T} / \mathrm{K}$ & $\mathrm{k} / \mathrm{s}^{-1}$ & $\Delta \mathrm{G}_{\text {rearr }}^{\neq} / \mathrm{kJ}(\mathrm{kcal}) \cdot \mathrm{mol}^{-1}$ \\
\hline 23-syn & 0.57 & \multirow{9}{*}{203} & $(6.92 \pm 0.74) \times 10^{-4}$ & $(61.3 \pm 0.2)(14.7 \pm 0.04)$ \\
\hline 23-syn & 0.95 & & $(5.81 \pm 0.31) \times 10^{-4}$ & $(61.6 \pm 0.1)(14.7 \pm 0.02)$ \\
\hline 24-syn & 4.98 & & $(4.92 \pm 0.29) \times 10^{-4}$ & $(61.9 \pm 0.1)(14.8 \pm 0.02)$ \\
\hline 24-syn & 2.23 & & $(5.00 \pm 0.35) \times 10^{-4}$ & $(61.9 \pm 0.1)(14.8 \pm 0.03)$ \\
\hline 23-anti & 0.49 & & $(4.14 \pm 0.12) \times 10^{-4}$ & $(62.2 \pm 0.05)(14.9 \pm 0.01)$ \\
\hline 23-anti & 4.82 & & $(4.09 \pm 0.05) \times 10^{-4}$ & $(62.2 \pm 0.02)(14.9 \pm 0.005)$ \\
\hline 23-anti & 2.15 & & $(4.47 \pm 0.04) \times 10^{-4}$ & $(62.1 \pm 0.01)(14.8 \pm 0.003)$ \\
\hline 24-anti & 2.30 & & $(3.30 \pm 0.07) \times 10^{-4}$ & $(62.6 \pm 0.04)(15.0 \pm 0.01)$ \\
\hline 24-anti & 4.50 & & $(3.24 \pm 0.09) \times 10^{-4}$ & $(62.6 \pm 0.05)(15.0 \pm 0.01)$ \\
\hline
\end{tabular}

${ }^{\mathrm{a}}$ reaction with ca. 2 equivalent of ${ }^{t} \mathrm{BuNC}$

${ }^{\mathrm{b}}$ reaction with more than 10 equivalent of ${ }^{t} \mathrm{BuNC}$

${ }^{c}$ reaction with ferrocene as an internal standard 
In order to check the error range caused by the possible fluctuation of temperature, temperature parameters of $\pm 2 \mathrm{~K}$ were used for calculation of $\Delta \mathrm{G}_{\text {rearr. And the results }}^{\neq}$ were collected in Table 2.

Table 2. $\Delta \mathrm{G}_{\text {rearr }}^{\neq}$at different $\mathrm{T}( \pm 2 \mathrm{~K})$ calculated from kinetic data

\begin{tabular}{|c|c|c|c|c|}
\hline${ }^{\mathrm{a}}$ Complex & $\delta\left({ }^{1} \mathrm{H}\right.$ NMR $)$ & $\Delta \mathrm{G}_{258}^{\neq} / \mathrm{kJ}(\mathrm{kcal}) \cdot \mathrm{mol}^{-1}$ & $\Delta \mathrm{G}_{256}^{\neq} / \mathrm{kJ}(\mathrm{kcal}) \cdot \mathrm{mol}^{-1}$ & $\Delta \mathrm{G}_{260}^{\mp} / \mathrm{kJ}(\mathrm{kcal}) \cdot \mathrm{mol}^{-1}$ \\
\hline 19-syn & 1.37 & $81.3(19.4)$ & $80.6(19.3)$ & $81.9(19.6)$ \\
\hline 19-syn & 2.54 & $81.4(19.4)$ & $80.7(19.3)$ & $82.0(19.6)$ \\
\hline 20-syn & 1.09 & $81.6(19.5)$ & $81.0(19.4)$ & $82.3(19.7)$ \\
\hline 20-syn & 0.67 & $81.7(19.5)$ & $81.0(19.4)$ & $82.3(19.7)$ \\
\hline 19-anti & 2.68 & $80.2(19.2)$ & $79.6(19.0)$ & $80.9(19.3)$ \\
\hline 20-anti & 1.13 & $80.5(19.2)$ & $79.8(19.1)$ & $81.1(19.4)$ \\
\hline${ }^{\mathrm{b}}$ Complex & $\delta\left({ }^{1} \mathrm{H}\right.$ NMR $)$ & $\Delta \mathrm{G}_{258}^{\neq} / \mathrm{kJ}(\mathrm{kcal}) \cdot \mathrm{mol}^{-1}$ & $\Delta \mathrm{G}_{256}^{\neq} / \mathrm{kJ}(\mathrm{kcal}) \cdot \mathrm{mol}^{-1}$ & $\Delta \mathrm{G}_{260}^{\neq} / \mathrm{kJ}(\mathrm{kcal}) \cdot \mathrm{mol}^{-1}$ \\
\hline 19-syn & 1.37 & $81.1(19.4)$ & $80.5(19.2)$ & $81.8(19.5)$ \\
\hline 19-syn & 2.54 & $81.2(19.4)$ & $80.6(19.3)$ & $81.9(19.6)$ \\
\hline 20-syn & 1.09 & $81.6(19.5)$ & $81.0(19.3)$ & $82.2(19.6)$ \\
\hline $20-s y n$ & 0.67 & $81.6(19.5)$ & $81.0(19.4)$ & $82.3(19.7)$ \\
\hline 20-syn & 2.45 & $81.5(19.5)$ & $80.8(19.3)$ & $82.1(19.6)$ \\
\hline 19-anti & 2.68 & $80.0(19.1)$ & $79.3(19.0)$ & $80.6(19.3)$ \\
\hline 19-anti & 1.91 & $79.9(19.1)$ & $79.3(18.9)$ & $80.6(19.2)$ \\
\hline 19-anti & 6.05 & $79.5(19.1)$ & $78.8(18.8)$ & $80.1(19.2)$ \\
\hline 20-anti & 1.13 & $80.4(19.2)$ & $79.7(19.0)$ & $81.0(19.4)$ \\
\hline${ }^{\mathrm{a}}$ Complex & $\delta\left({ }^{1} \mathrm{H}\right.$ NMR $)$ & $\Delta \mathrm{G}_{243}^{\neq} / \mathrm{kJ}(\mathrm{kcal}) \cdot \mathrm{mol}^{-1}$ & $\Delta \mathrm{G}_{241}^{\neq} / \mathrm{kJ}(\mathrm{kcal}) \cdot \mathrm{mol}^{-1}$ & $\Delta \mathrm{G}_{245}^{\neq} / \mathrm{kJ}(\mathrm{kcal}) \cdot \mathrm{mol}^{-1}$ \\
\hline 25-syn & 0.036 & $75.4(18.0)$ & $74.8(17.9)$ & $76.0(18.2)$ \\
\hline $17-s y n$ & 0.62 & $75.4(18.0)$ & $74.7(17.9)$ & $76.0(18.2)$ \\
\hline 25-anti & -0.30 & $75.2(18.0)$ & $74.6(17.8)$ & $75.8(18.1)$ \\
\hline 17-anti & 0.67 & $75.2(18.0)$ & $74.6(17.8)$ & $75.8(18.1)$ \\
\hline a, complex & $\delta\left({ }^{1} \mathrm{H}\right.$ NMR $)$ & $\Delta \mathrm{G}_{243}^{\neq} / \mathrm{kJ}(\mathrm{kcal}) \cdot \mathrm{mol}^{-1}$ & $\Delta \mathrm{G}_{241}^{\neq} / \mathrm{kJ}(\mathrm{kcal}) \cdot \mathrm{mol}^{-1}$ & $\Delta \mathrm{G}_{245}^{\mp} / \mathrm{kJ}(\mathrm{kcal}) \cdot \mathrm{mol}^{-1}$ \\
\hline 25-syn & 0.037 & $75.5(18.0)$ & $74.9(17.9)$ & $76.2(18.2)$ \\
\hline $17-s y n$ & 0.42 & $75.5(18.0)$ & $74.8(17.9)$ & $76.1(18.2)$ \\
\hline 17-syn & 0.62 & $75.5(18.0)$ & $74.8(17.9)$ & $76.1(18.2)$ \\
\hline 25-anti & -0.30 & $75.4(18.0)$ & $74.8(17.9)$ & $76.0(18.2)$ \\
\hline 17-anti & -0.35 & $75.3(18.0)$ & $74.7(17.8)$ & $75.9(18.1)$ \\
\hline 17-anti & 0.67 & $75.4(18.0)$ & $74.7(17.8)$ & $76.0(18.2)$ \\
\hline${ }^{\mathrm{b}}$ Complex & $\delta\left({ }^{1} \mathrm{H}\right.$ NMR $)$ & $\Delta \mathrm{G}_{243}^{\ddagger} / \mathrm{kJ}(\mathrm{kcal}) \cdot \mathrm{mol}^{-1}$ & $\Delta \mathrm{G}_{241}^{ \pm} / \mathrm{kJ}(\mathrm{kcal}) \cdot \mathrm{mol}^{-1}$ & $\Delta \mathrm{G}_{245}^{\ddagger} / \mathrm{kJ}(\mathrm{kcal}) \cdot \mathrm{mol}^{-1}$ \\
\hline 25-syn & -0.049 & $74.6(17.8)$ & $74.0(17.7)$ & $75.2(18.0)$ \\
\hline $17-s y n$ & 0.60 & $74.6(17.8)$ & $74.0(17.7)$ & $75.2(18.0)$ \\
\hline $17-s y n$ & 2.20 & $74.6(17.8)$ & $73.9(17.7)$ & $75.2(18.0)$ \\
\hline 17-syn & 0.34 & $74.6(17.8)$ & $74.0(17.7)$ & $75.2(18.0)$ \\
\hline
\end{tabular}




\begin{tabular}{|c|c|c|c|c|}
\hline 25-anti & -0.39 & $74.5(17.8)$ & $73.9(17.7)$ & $75.1(18.0)$ \\
\hline 17-anti & -0.45 & $74.5(17.8)$ & $73.9(17.7)$ & $75.2(18.0)$ \\
\hline 17-anti & 0.65 & $74.4(17.8)$ & $73.8(17.6)$ & $75.1(17.9)$ \\
\hline${ }^{\mathrm{b}}$ Complex & $\delta\left({ }^{1} \mathrm{H}\right.$ NMR $)$ & $\Delta \mathrm{G}_{218}^{\ddagger} / \mathrm{kJ}(\mathrm{kcal}) \cdot \mathrm{mol}^{-1}$ & $\Delta \mathrm{G}_{216}^{\ddagger} / \mathrm{kJ}(\mathrm{kcal}) \cdot \mathrm{mol}^{-1}$ & $\Delta \mathrm{G}_{220}^{\neq} / \mathrm{kJ}(\mathrm{kcal}) \cdot \mathrm{mol}^{-1}$ \\
\hline 21-syn & 5.04 & $64.2(15.4)$ & $63.6(15.2)$ & $64.8(15.5)$ \\
\hline 22-syn & 8.07 & $64.0(15.3)$ & $63.4(15.2)$ & $64.6(15.4)$ \\
\hline 22-syn & 5.68 & $64.5(15.4)$ & $63.9(15.3)$ & $65.1(15.6)$ \\
\hline 21-anti & 7.84 & $66.2(15.8)$ & $65.6(15.7)$ & $66.8(16.0)$ \\
\hline 21-anti & 2.54 & $66.2(15.8)$ & $65.6(15.7)$ & $66.8(16.0)$ \\
\hline 22-anti & 5.52 & $66.2(15.8)$ & $65.6(15.7)$ & $66.8(16.0)$ \\
\hline${ }^{\mathrm{b}}$ Complex & $\delta\left({ }^{1} \mathrm{H}\right.$ NMR $)$ & $\Delta \mathrm{G}_{203}^{\ddagger} / \mathrm{kJ}(\mathrm{kcal}) \cdot \mathrm{mol}^{-1}$ & $\Delta \mathrm{G}_{201}^{\ddagger} / \mathrm{kJ}(\mathrm{kcal}) \cdot \mathrm{mol}^{-1}$ & $\Delta \mathrm{G}_{205}^{\ddagger} / \mathrm{kJ}(\mathrm{kcal}) \cdot \mathrm{mol}^{-1}$ \\
\hline 23-syn & 0.57 & $61.3(14.7)$ & $60.7(14.5)$ & $62.0(14.8)$ \\
\hline 23-syn & 0.95 & $61.6(14.7)$ & $61.0(14.6)$ & $62.3(14.9)$ \\
\hline 24-syn & 4.98 & $61.9(14.8)$ & $61.3(14.6)$ & $62.6(15.0)$ \\
\hline 24-syn & 2.23 & $61.9(14.8)$ & $61.3(14.6)$ & $62.5(14.9)$ \\
\hline 23-anti & 0.49 & $62.2(14.9)$ & $61.6(14.7)$ & $62.8(15.0)$ \\
\hline 23-anti & 4.82 & $62.2(14.9)$ & $61.6(14.7)$ & $62.9(15.0)$ \\
\hline 23-anti & 2.15 & $62.1(14.8)$ & $61.4(14.7)$ & $62.7(15.0)$ \\
\hline 24-anti & 2.30 & $62.6(15.0)$ & $62.0(14.8)$ & $63.2(15.1)$ \\
\hline 24-anti & 4.50 & $62.6(15.0)$ & $62.0(14.8)$ & $63.3(15.1)$ \\
\hline
\end{tabular}

${ }^{\mathrm{a}}$ reaction with ca. 2 equivalent of ${ }^{t} \mathrm{BuNC}$

${ }^{\mathrm{b}}$ reaction with more than 10 equivalent of ${ }^{t} \mathrm{BuNC}$

${ }^{c}$ reaction with ferrocene as an internal standard 
In order to make sure that there was no change of the total amount of the kinetic products and the thermodynamic products in such kind of isomerization, $1.2 \mathrm{mg}$ of ferrocene was used as an internal standard in the isomerization of complexes 17. Selected integration data of protons was collected in Table $\mathbf{3}$ and Table $\mathbf{4}$.

Table 3. The ratios based on the same kind of group $\left(\mathrm{CH}_{3}\right)$

\begin{tabular}{|c|c|c|c|c|c|c|c|}
\hline & $\delta_{25-\text { anti }}$ & $\delta_{17-\text { anti }}$ & $\delta_{25-\text { syn }}$ & $\delta_{17-\text { syn }}$ & Total & $\delta_{\text {Ferrocene }}$ & \multirow{2}{*}{ Ratio } \\
\cline { 2 - 3 } & -0.30 & -0.35 & 0.037 & 0.42 & $(3 \mathrm{H})$ & 3.93 & \\
\hline 1 & 105.41 & 34.21 & 149.80 & 44.14 & 333.56 & 165.85 & 2.01 \\
\hline 2 & 101.20 & 39.03 & 144.03 & 49.45 & 333.71 & 179.54 & 1.86 \\
\hline 3 & 97.36 & 42.57 & 138.72 & 54.77 & 333.42 & 180.35 & 1.85 \\
\hline 5 & 89.91 & 50.63 & 129.50 & 64.60 & 334.64 & 180.61 & 1.85 \\
\hline 10 & 73.31 & 67.28 & 106.57 & 86.35 & 333.51 & 181.43 & 1.84 \\
\hline 15 & 59.52 & 80.50 & 87.75 & 103.88 & 331.65 & 181.46 & 1.83 \\
\hline 20 & 48.08 & 91.58 & 72.89 & 118.76 & 331.31 & 181.06 & 1.83 \\
\hline 30 & 30.63 & 107.41 & 49.05 & 141.03 & 328.12 & 181.25 & 1.81 \\
\hline 40 & 19.76 & 118.01 & 32.80 & 156.22 & 326.79 & 181.43 & 1.80 \\
\hline 50 & 12.02 & 124.94 & 21.89 & 166.37 & 325.22 & 181.14 & 1.80 \\
\hline 55 & 9.09 & 128.75 & 17.89 & 170.01 & 325.74 & 182.06 & 1.79 \\
\hline 60 & 7.56 & 129.58 & 14.58 & 173.75 & 325.47 & 181.19 & 1.80 \\
\hline
\end{tabular}

Table 4. The ratios based on different kinds of groups $\left(\mathrm{CH}_{3}\right.$ and $\left.{ }^{t} \mathrm{Bu}\right)$

\begin{tabular}{|c|c|c|c|c|c|c|c|c|c|}
\hline & $\delta_{25 \text {-anti }}$ & $\delta_{25-s y n}$ & \multirow{2}{*}{$\begin{array}{c}\text { Total }_{1} \\
(3 \mathrm{H})\end{array}$} & \multirow{2}{*}{$\begin{array}{c}\delta_{17 \text {-anti }} \\
0.67 \\
\end{array}$} & \multirow{2}{*}{$\begin{array}{c}\delta_{17-s y n} \\
0.62 \\
\end{array}$} & \multirow{2}{*}{$\begin{array}{c}\text { Total }_{2} \\
(9 \mathrm{H})\end{array}$} & \multirow{2}{*}{ Total $_{3} / \mathrm{H}$} & $\delta_{\text {Ferrocene }}$ & \multirow{2}{*}{ Ratio } \\
\hline & -0.30 & 0.037 & & & & & & 3.93 & \\
\hline 1 & 105.41 & 149.80 & 255.21 & 113.03 & 145.24 & 258.27 & 113.77 & 165.85 & 0.68 \\
\hline 2 & 101.20 & 144.03 & 245.23 & 121.43 & 160.76 & 282.19 & 113.10 & 179.54 & 0.63 \\
\hline 3 & 97.36 & 138.72 & 236.08 & 137.97 & 178.88 & 316.85 & 113.90 & 180.35 & 0.63 \\
\hline 5 & 89.91 & 129.50 & 219.41 & 160.29 & 213.17 & 373.46 & 114.63 & 180.61 & 0.63 \\
\hline 10 & 73.31 & 106.57 & 179.88 & 208.29 & 281.64 & 489.93 & 114.40 & 181.43 & 0.63 \\
\hline 15 & 59.52 & 87.75 & 147.27 & 247.55 & 338.00 & 585.55 & 15 & 181.46 & 0.63 \\
\hline 20 & 48 & 72 & 120 & 28 & .71 & 71 & & & .64 \\
\hline 30 & 30.63 & 49.05 & 79.68 & 329.05 & 463.51 & 792.56 & & 181.25 & 0.63 \\
\hline 40 & 19.76 & 32.80 & 52.56 & 364.77 & 513.23 & 878 & 115.08 & 181.43 & 0.63 \\
\hline 50 & 12.02 & 21.89 & 33.91 & 384.41 & 547.74 & 932.15 & 114.88 & 181.14 & 0.63 \\
\hline 55 & 9.09 & 17.89 & 26.98 & 392.88 & 567.29 & 960.17 & 115.68 & 182.06 & 0.64 \\
\hline 60 & 7.56 & 14.58 & 22.14 & 402.09 & 571.04 & 973.13 & 115.50 & 181.19 & 0.64 \\
\hline
\end{tabular}


According the experimental data above, the average $\Delta \mathrm{G}_{\text {rearr }}^{\neq}$of each isomerization is generated in Table $\mathbf{5}$.

Table 5. Thermal isomerization of iminoacyl ansa-zirconocenes

\begin{tabular}{lccccccccc}
\hline $\mathrm{R}$ (Complexes) & \multicolumn{2}{c}{$\mathrm{Ph}$} & \multicolumn{2}{c}{$\mathrm{Me}$} & \multicolumn{2}{c}{$\mathrm{Ph}$} & \multicolumn{2}{c}{$\mathrm{Me}$} \\
\hline $\mathrm{T}_{\mathrm{isom}} /{ }^{\circ} \mathrm{C}$ & \multicolumn{2}{c}{-15} & \multicolumn{2}{c}{-30} & \multicolumn{2}{c}{-55} & \multicolumn{2}{c}{-70} \\
\cline { 2 - 11 } & I Isomerization & II & I & II & III & IV & III & IV \\
$\Delta \mathrm{G}_{\text {rearr }}^{\neq}$ & $/$ & 19.5 & 19.1 & 18.0 & 17.8 & 15.5 & 15.9 & 14.7 & 14.9 \\
$\mathrm{kcal} \cdot \mathrm{mol}^{-1}$ & \pm 0.2 & \pm 0.2 & \pm 0.2 & \pm 0.2 & \pm 0.2 & \pm 0.2 & \pm 0.2 & \pm 0.2 \\
\hline
\end{tabular}

${ }^{\text {a }}$ See Scheme 7

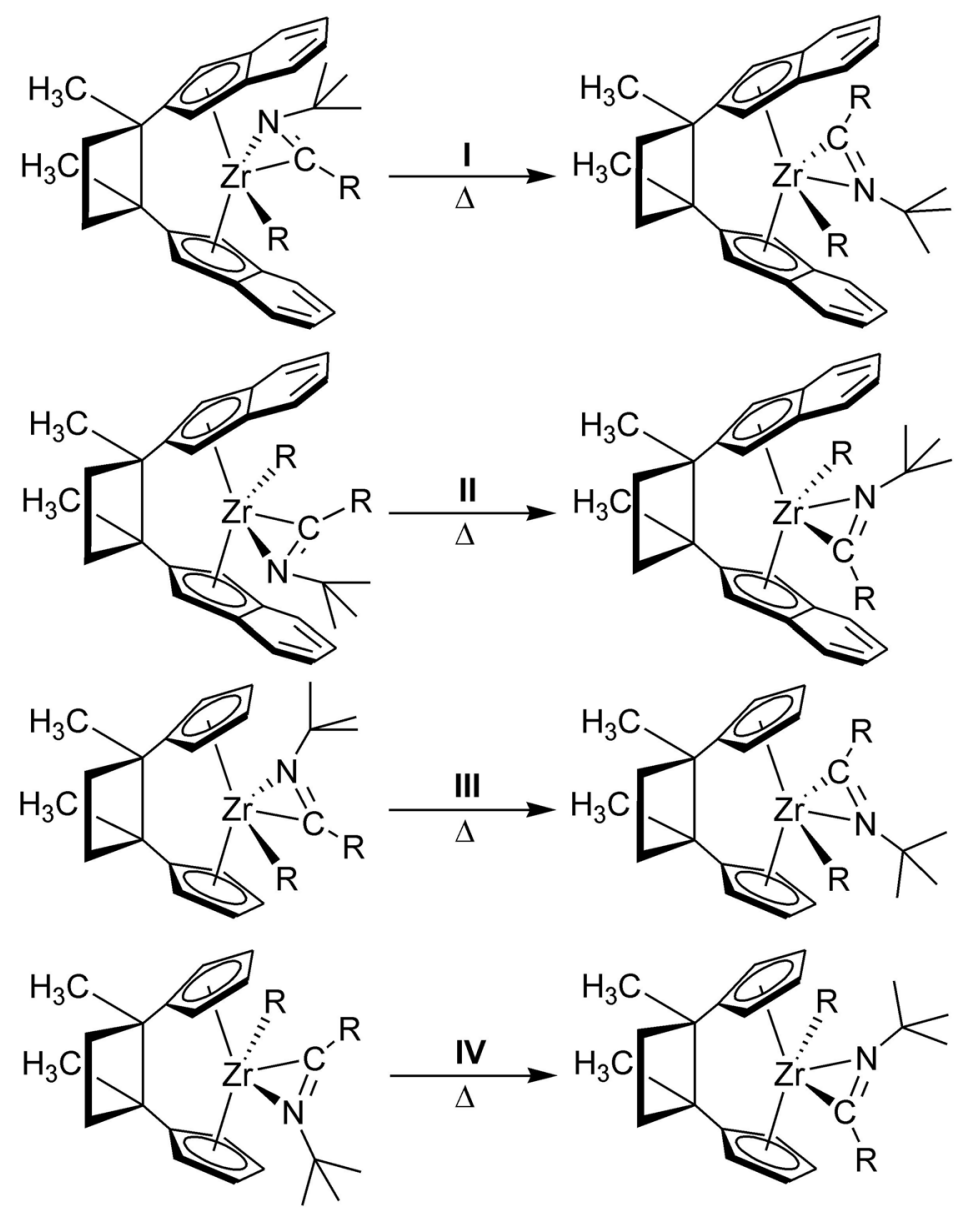

Scheme 7 